Prepared in cooperation with the Missouri Department of Natural Resources

\title{
Water and Streambed-Sediment Quality in the Upper Elk River Basin, Missouri and Arkansas,
} 2004-06

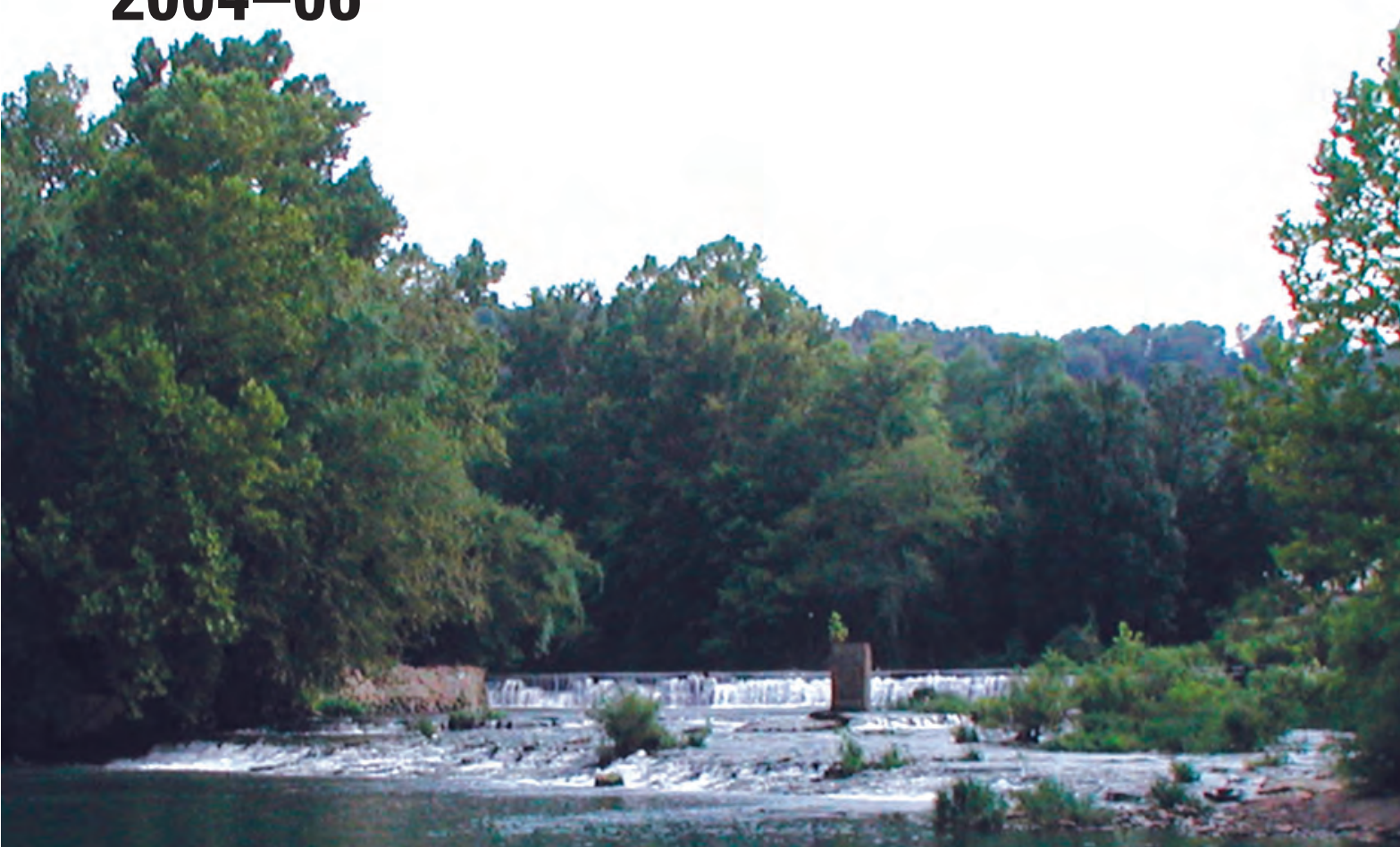

- iscientific.Jnyestigations Report 2007-5181
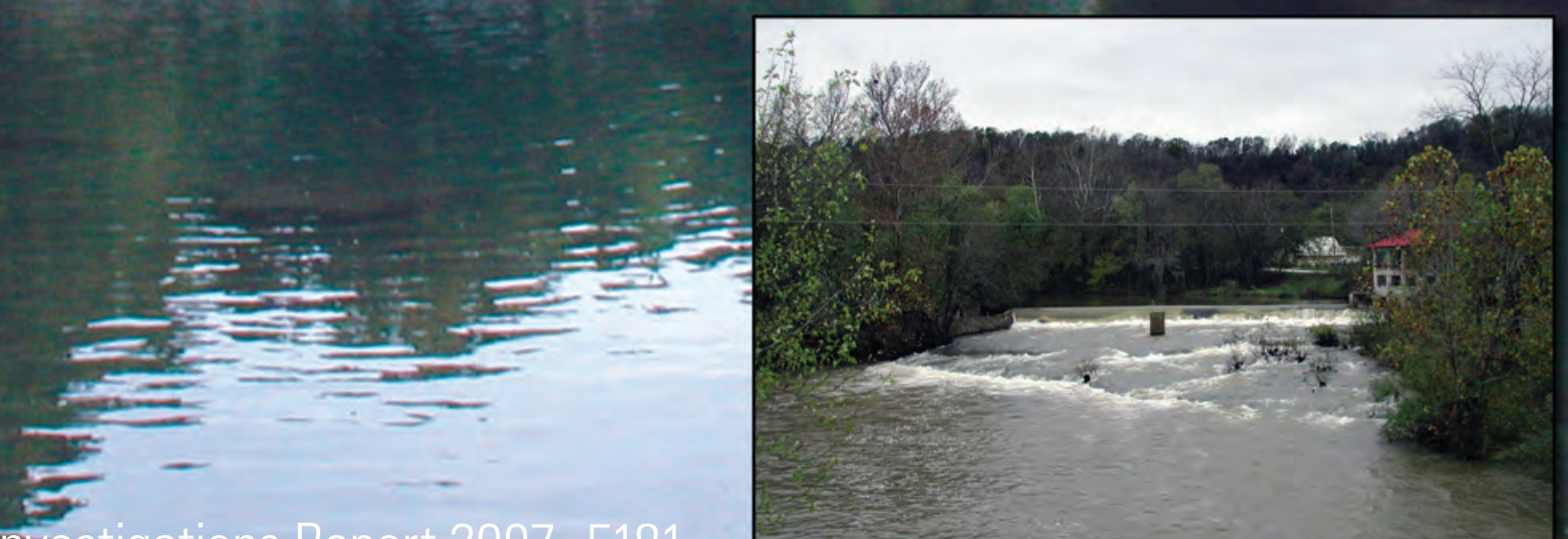

Scientific Jnve

$y$ -

U.S. Department of the Interior

U.S. Geological Survey

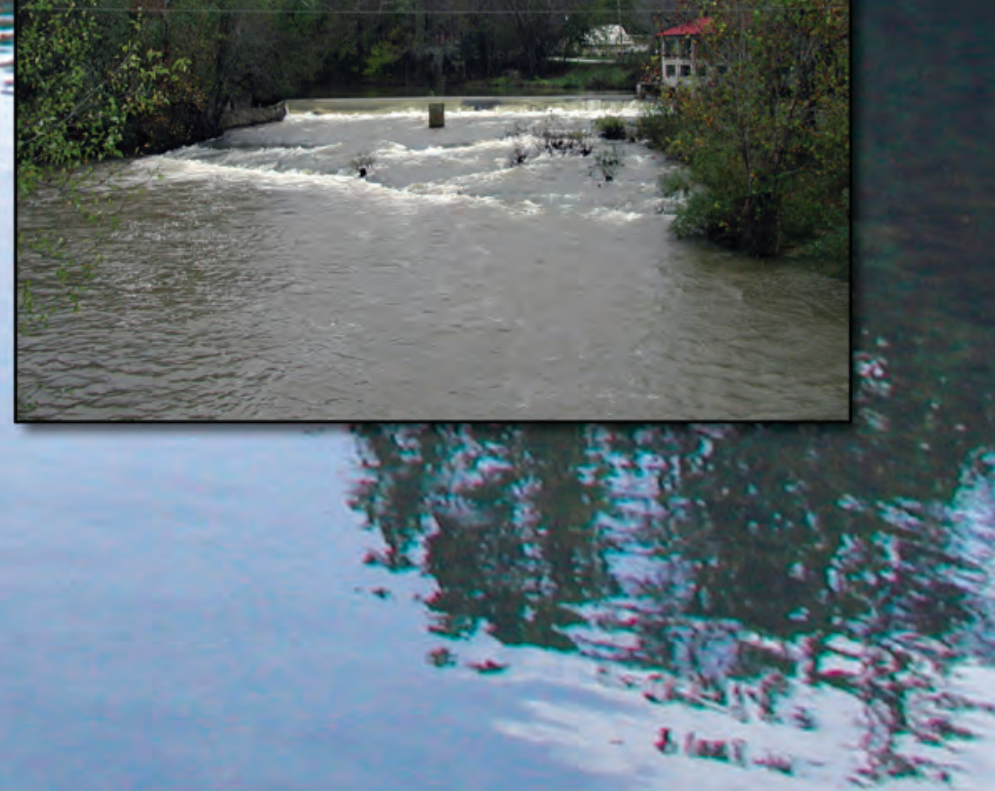


Cover Photographs. L Little Sugar Creek near Pineville, Missouri (07188838), September 2004 (inset: November 2004). 


\section{Water and Streambed-Sediment Quality in the Upper Elk River Basin, Missouri and Arkansas, 2004-06}

By Brenda J. Smith, Joseph M. Richards, and John G. Schumacher

Prepared in cooperation with the Missouri Department of Natural Resources

Scientific Investigations Report 2007-5181 


\section{U.S. Department of the Interior DIRK KEMPTHORNE, Secretary}

\section{U.S. Geological Survey \\ Mark D. Myers, Director}

\section{U.S. Geological Survey, Reston, Virginia: 2007}

For product and ordering information:

World Wide Web: http://www.usgs.gov/pubprod

Telephone: 1-888-ASK-USGS

For more information on the USGS--the Federal source for science about the Earth, its natural and living resources, natural hazards, and the environment:

World Wide Web: http://www.usgs.gov

Telephone: 1-888-ASK-USGS

Any use of trade, product, or firm names is for descriptive purposes only and does not imply endorsement by the U.S. Government.

Although this report is in the public domain, permission must be secured from the individual copyright owners to reproduce any copyrighted materials contained within this report.

Suggested citation:

Smith, B.J., Richards, J.M., and Schumacher, J.G., 2007, Water and streambed-sediment quality in the Upper Elk River Basin, Missouri and Arkansas, 2004-06: U.S. Geological Survey Scientific Investigations Report 2007-5181, 53 p. 


\section{Contents}

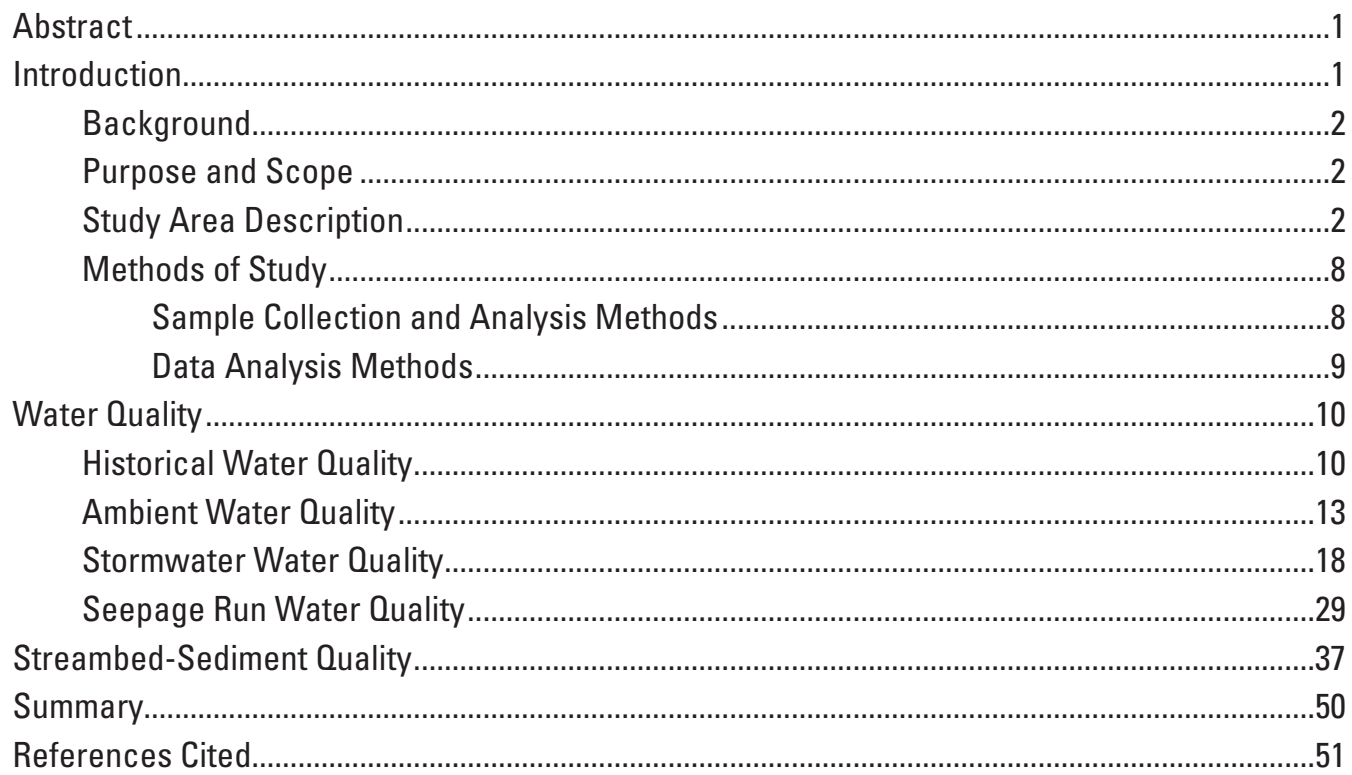

\section{Figures}

1. Map showing location of the Elk River Basin ...................................................................

2. Box plots showing discharge at the Elk River near Tiff City, 1960 through September 2006

3. Graphs showing monthly $(A)$ and cumulative $(B)$ departure from normal precipitation at Anderson, Missouri, January 1999 through September 2006 ..................6

4. Map showing land use in the Upper Elk River Basin, Missouri and Arkansas ..................7

5-9. Box plots showing-

5. The distribution of selected major ion concentrations in historical waterquality samples within the Upper Elk River Basin

6. The distribution of nutrient concentrations in historical water-quality samples within the Upper Elk River Basin

7. Distribution of total phosphorus and nitrate as nitrogen concentrations, by decades, in samples from the Elk River near Tiff City.

8. The distribution of total phosphorus concentrations in samples from the Elk River near Tiff City, 1962-2006

9. The distribution of nitrate as nitrogen concentrations in samples from the Elk River near Tiff City, 1960-2006

10. Scatter plot showing the relation between nitrate as nitrogen concentrations and discharge in samples from the Elk River near Tiff City, 1960 to September 2006

11. Trilinear diagram of major ions in samples from the Upper Elk River Basin, October 2004 through September 2006. 
12-13. Box plots showing -

12. The distribution of nutrient concentrations in samples from the Upper Elk River Basin, October 2004 through September 2006

13. The distribution of monthly nutrient loads in samples from the Upper Elk River Basin, October 2004 through September 2006

14-15. Graphs showing-

14. Relation of nitrate as nitrogen concentrations in samples from the Upper Elk River Basin to discharge in the Elk River near Tiff City, October 2004 through September 2006

15. Relation of total phosphorus concentrations in samples from the Upper Elk River Basin to discharge in Little Sugar Creek near Pineville, October 2004 through September 2006

16-17. Box plots showing-

16. The distribution of nutrient concentrations in stormwater samples in the Upper Elk River Basin, October 2004 through December 2006

17. The distribution of nutrient loads in stormwater samples in the Upper Elk River Basin, October 2004 through December 2006

18. Map showing location of seepage run sites and discharge values in the Upper Elk River Basin

19-22. Bar charts showing-

19. Concentration of nitrate as nitrogen in samples from the seepage run, July 31 through August 3, 2006, in the Upper Elk River Basin

20. Concentration of total phosphorus in samples from the seepage run, July 31 through August 3, 2006, in the Upper Elk River Basin

21. Sodium, chloride, and sulfate concentrations in samples from the seepage run, November 2006, in the Upper Elk River Basin.

22. Nutrient concentrations in samples from the seepage run, November 2006, in the Upper Elk River Basin.

23. Maps showing concentrations of leachable nutrients normalized to organic carbon content in streambed-sediment samples in the Upper Elk River Basin, August 2005

24. Boxplots showing concentrations of selected nutrients in leachate samples normalized to organic carbon content in streambed-sediment samples in the Upper Elk River Basin, August 2005

25. Maps showing concentrations of selected trace elements normalized to organic carbon content in streambed-sediment samples in the Upper Elk River Basin, August 2005

26-27. Graphs showing-

26. Relation of selected trace-element concentrations and iron in the less than 63-micrometer size fraction of streambed-sediment samples from the Upper Elk River Basin, August 2005

27. The trend of cadmium and zinc in streambed-sediment samples in the Upper Elk River Basin, August 2005. 


\section{Tables}

1. Water-quality sampling sites and annual mean discharge within the Upper Elk River Basin, Missouri, 2004-06.

2. Summary statistics for selected physical properties, inorganic constituents, and nutrients in the Upper Elk River Basin, October 2004 through September 2006

3. Values of physical properties, major ion and nutrient concentrations, and bacteria densities in stormwater samples in the Upper Elk River Basin, October 2004 through December 2006

4. Values of physical properties, major ion and nutrient concentrations, and bacteria densities in samples from the seepage run, July 31 through August 3, 2006, in the Upper Elk River Basin.

5. Wastewater indicator compounds analyzed and reporting limit for samples collected during the seepage run, July 31-August 3, 2006, in the Upper Elk River Basin

6. Concentrations of wastewater indicator and pharmaceutical compounds detected in samples from the seepage run, July 31-August 3, 2006, in the Upper Elk River Basin.

7. Values of physical properties, major ion and nutrient concentrations, bacteria densities, and wastewater indicator and pharmaceutical compound concentrations in samples from the seepage run, November 2006, in the Upper Elk River Basin.

8. Nutrient and trace-element concentrations from streambed-sediment samples collected from the Upper Elk River Basin, August 2005 


\section{Conversion Factors and Datum}

\begin{tabular}{|c|c|c|}
\hline Multiply & By & To obtain \\
\hline \multicolumn{3}{|c|}{ Length } \\
\hline inch (in.) & 2.54 & centimeter $(\mathrm{cm})$ \\
\hline foot (ft)) & 0.3048 & meter $(\mathrm{m})$ \\
\hline mile (mi) & 1.609 & kilometer $(\mathrm{km})$ \\
\hline \multicolumn{3}{|c|}{ Area } \\
\hline acre & 4,047 & square meter $\left(\mathrm{m}^{2}\right)$ \\
\hline square mile $\left(\mathrm{mi}^{2}\right)$ & 2.590 & square kilometer $\left(\mathrm{km}^{2}\right)$ \\
\hline \multicolumn{3}{|c|}{ Flow rate } \\
\hline cubic foot per second $\left(\mathrm{ft}^{3} / \mathrm{s}\right)$ & 0.02832 & cubic meter per second $\left(\mathrm{m}^{3} / \mathrm{s}\right)$ \\
\hline \multicolumn{3}{|r|}{ 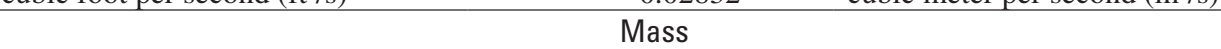 } \\
\hline ton, short $(2,000 \mathrm{lb})$ & 0.9072 & megagram $(\mathrm{Mg})$ \\
\hline
\end{tabular}

Temperature in degrees Celsius $\left({ }^{\circ} \mathrm{C}\right)$ may be converted to degrees Fahrenheit $\left({ }^{\circ} \mathrm{F}\right)$ as follows:

$$
{ }^{\circ} \mathrm{F}=\left(1.8 x^{\circ} \mathrm{C}\right)+32
$$

Temperature in degrees Fahrenheit $\left({ }^{\circ} \mathrm{F}\right)$ may be converted to degrees Celsius $\left({ }^{\circ} \mathrm{C}\right)$ as follows:

$$
{ }^{\circ} \mathrm{C}=\left({ }^{\circ} \mathrm{F}-32\right) / 1.8
$$

Vertical coordinate information is referenced to the North American Vertical Datum of 1988 (NAVD 88).

Horizontal coordinate information is referenced to the North American Datum of 1983 (NAD 83).

Altitude, as used in this report, refers to distance above the vertical datum.

Specific conductance is given in microsiemens per centimeter at 25 degrees Celsius $(\mu \mathrm{S} / \mathrm{cm}$ at $\left.25^{\circ} \mathrm{C}\right)$.

Concentrations of chemical constituents in water are given either in milligrams per liter ( $\mathrm{mg} / \mathrm{L}$ ) or micrograms per liter $(\mu \mathrm{g} / \mathrm{L})$. 


\title{
Water and Streambed-Sediment Quality in the Upper Elk River Basin, Missouri and Arkansas, 2004-06
}

\author{
By Brenda J. Smith, Joseph M. Richards, and John G. Schumacher
}

\section{Abstract}

The U.S. Geological Survey, in cooperation with the Missouri Department of Natural Resources, collected water and streambedsediment samples in the Upper Elk River Basin in southwestern Missouri and northwestern Arkansas from October 2004 through December 2006. The samples were collected to determine the stream-water quality and streambed-sediment quality.

In 1998, the Missouri Department of Natural Resources included a 21.5-mile river reach of the Elk River on the 303(d) list of impaired waters in Missouri as required by Section 303(d) of the Federal Clean Water Act. The Elk River is on the 303(d) list for excess nutrient loading.

The total phosphorus distribution by decade indicates that the concentrations since 2000 have increased significantly from those in the 1960s, 1980s, and 1990s. The nitrate as nitrogen (nitrate) concentrations also have increased significantly in post-1985 from pre-1985 samples collected at the Elk River near Tiff City. Concentrations have increased significantly since the 1960s. Concentrations in the 1970s and 1980s, though similar, have increased from those in the 1960s, and the concentrations from the 1990s and 2000s increased still more. Nitrate concentrations significantly increased in samples that were collected during large discharges (greater than 355 cubic feet per second) from the Elk River near Tiff City.

Nitrate concentrations were largest in Indian Creek. Several sources of nitrate are present in the basin, including poultry facilities in the upper part of the basin, effluent inflow from communities of Anderson and Lanagan, land-applied animal waste, chemical fertilizer, and possible leaking septic systems. Total phosphorus concentrations were largest in Little Sugar Creek. The median concentration of total phosphorus from samples from Little Sugar Creek near Pineville was almost four times the median concentration in samples from the Elk River near Tiff City.

Median concentrations of nutrient species were greater in the stormwater samples than the median concentrations in the ambient samples. Nitrate concentrations in stormwater samples ranged from 133 to 179 percent of the concentration in the ambient samples. The total phosphorus concentrations in the stormwater samples ranged from about 200 to more than 600 percent of the concentration in the ambient samples.
Base-flow conditions as reflected by the seepage run of the summer of 2006 indicate that 52 percent of the discharge at the Elk River near Tiff City is contributed by Indian Creek. Little Sugar Creek contributes 32 percent and Big Sugar Creek 9 percent of the discharge in the Elk River near Tiff City. Only about 7 percent of the discharge at Tiff City comes from the mainstem of the Elk River.

Concentrations of dissolved ammonia plus organic nitrogen as nitrogen, dissolved ammonia as nitrogen, dissolved phosphorus, and dissolved orthophosphorus were detected in all streambed-sediment leachate samples.

Concentrations of leachable nutrients in streambedsediment samples generally tended to be slightly larger along the major forks of the Elk River as compared to tributary sites, with sites in the upper reaches of the major forks having among the largest concentrations. Concentrations of leachable nutrients in the major forks generally decreased with increasing distance downstream.

\section{Introduction}

The Elk River Basin (fig. 1) encompasses about 1,030 square miles $\left(\mathrm{mi}^{2}\right)$ in parts of southwestern Missouri, northwestern Arkansas, and northeastern Oklahoma (Missouri Watershed Information Network, 2006). More than $850 \mathrm{mi}^{2}$ are in Missouri (Missouri Department of Conservation, 2006). The headwaters of the Elk River are near Pineville, Missouri, at the confluence of Big Sugar and Little Sugar Creeks. The Elk River flows westerly into the Grand Lake O' the Cherokees in northeastern Oklahoma. Much of the basin is within McDonald County, Missouri. The rest of the basin is in Barry and Newton Counties, Missouri, Benton County, Arkansas, and Ottawa and Delaware Counties, Oklahoma. The largest municipalities partially or completely within the basin are Bentonville and Bella Vista, Arkansas; and Noel, Anderson, Goodman, and Neosho, Missouri (Missouri Watershed Information Network, 2006). Smaller communities within the basin include Wheaton, Stella, Lanagan, and Pineville, Missouri. Major tributaries to the Elk River include Big Sugar Creek, Little Sugar Creek (headwaters in Arkansas), Indian Creek, and Buffalo Creek (Missouri Department of Conservation, 
2006). Two of the more economically important activities in the Elk River Basin are livestock production and recreational activities. In 1997, McDonald, Barry, and Newton Counties were ranked second, third, and fourth in Missouri counties for the market value of livestock and poultry products with a combined value of more than $\$ 418,000,000$ (Missouri Watershed Information Network, 2006). Recreational activities within the Elk River Basin include boating (primarily canoes and kayaks), swimming, tubing (use of personal flotation device to float downstream on the river), fishing, camping, hiking, and hunting.

\section{Background}

The Missouri Department of Natural Resources (MDNR) has designated specific uses for water bodies in the State. Uses for Big Sugar Creek, Little Sugar Creek, Indian Creek, and the Elk River are irrigation, livestock and wildlife watering, protection of warm-water aquatic life and human health-fish consumption, cool-water fishery, whole-body-contact recreation, and secondary contact recreation (Missouri Department of Natural Resources, 2005). Whole-body-contact recreation includes public swimming beaches and property where wholebody-contact recreational activities are open to the public. Secondary contact recreation includes fishing, wading, commercial and recreational boating, and activities in which users do not swim or float in the water (Missouri Department of Natural Resources, 2005).

Section 303(d) of the Federal Clean Water Act requires that each State identify those stream segments with documented pollution problems for which existing pollution controls are not adequate to meet the Statewide water-quality standards. For these impaired stream segments, States are required to establish total maximum daily loads (TMDLs) of the identified pollutant. A TMDL specifies the maximum amount of the identified pollutant allowed to be present in a water body, allocates allowable pollutant loads among sources, and provides the basis for attaining or maintaining waterquality standards within the affected water body (Davis and Barr, 2006).

In 1998, the MDNR included a 21.5-mile river reach of the Elk River on the 303(d) list of impaired waters in Missouri as required by Section 303(d) of the Federal Clean Water Act. The Elk River is on the 303(d) list for excess nutrient loading (Missouri Department of Natural Resources, 1998). The primary source cited was nonpoint source pollution from livestock production, although both point and nonpoint sources contribute nutrients to the streams. A trend analysis that indicated nutrient accumulation was occurring with time and repeated complaints from the public about nuisance algae were the basis for the 303(d) listing (Missouri Department of Natural Resources, 2004). Also included on the list (river miles affected) were Big Sugar Creek, McDonald and Barry Counties (35); Little Sugar Creek, McDonald County (11); North Indian Creek, Newton County (5); South Indian Creek,
Newton County (9); and Indian Creek in McDonald and Newton Counties (26).

Nutrients are essential to plant growth. Aquatic vegetation, such as algae, depends on nitrogen and phosphorus compounds for a nutrient supply, but the availability of other required elements also may affect growth. Dense growths of algae, or algal blooms, usually occur when the concentration of nitrogen or phosphorus increases above normal, ambient concentrations. During an algal bloom, a lake or stream becomes undesirable for recreational use. After an algal bloom die-off, bacterial decomposition of dead algal cells, which sink to the bottom of the water, results in the depletion of dissolved oxygen. This condition can result in fish kills and other negative effects on aquatic life (Davis and Schumacher, 1992). Although nitrogen and phosphorus are essential for algal growth, phosphorus availability is considered to be the limiting factor in many natural waters (Hem, 1985). Nitrate concentrations are attributed to drainage from nearby barnyards or septic tanks and nitrogen fertilizer use. Phosphorus is a component of sewage effluent and is present in animal metabolic waste; domestic and industrial effluent probably is a large source of phosphorus in surface water (Hem, 1985).

\section{Purpose and Scope}

The purpose of this report is to present the results of a detailed assessment on stream-water quality and streambedsediment quality in the Upper Elk River Basin in southwestern Missouri and northwestern Arkansas. To provide technical information needed by the MDNR to assess TMDLs for the Elk River and its tributaries, the U.S. Geological Survey (USGS), in cooperation with the MDNR, collected and analyzed water and streambed-sediment samples in the Upper Elk River Basin from October 2004 to December 2006. Measurements of physical properties, fecal-indicator bacteria, nutrients, organic wastewater compounds, and pharmaceutical compounds are discussed. Monthly water-quality samples were collected at sites on the Big Sugar Creek, Little Sugar Creek, Indian Creek, and the Elk River from October 2004 through September 2006. Streambed-sediment samples were collected during the summer of 2005, water-quality samples were collected during low-base flow conditions in the summer and fall of 2006, and stormwater samples were collected during selected storms from November 2004 through December 2006.

\section{Study Area Description}

The Elk River Basin is in the Springfield Plateaus physiographic section of the Ozark Plateaus physiographic province (Fenneman, 1938). Rocks in the basin predominantly are limestone, shale, and sandstone of Mississippian age (Missouri Watershed Information Network, 2006). Land-surface elevations range from 1,500 feet (ft) in the uplands to about $800 \mathrm{ft}$ at the Missouri-Oklahoma state line (Missouri Department of 


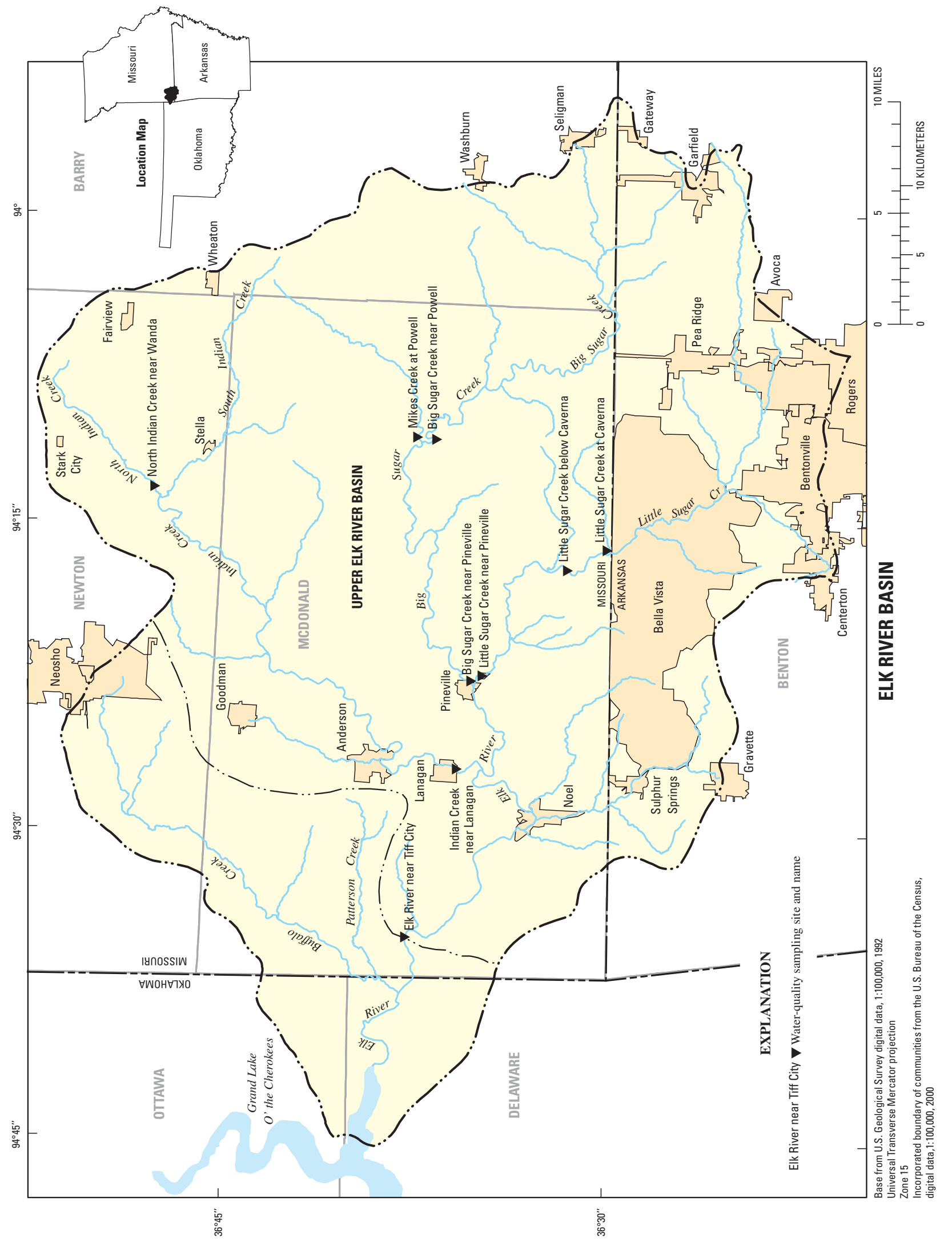

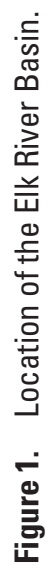


Natural Resources, 2004). The slightly rolling hills contain numerous karst features (sinkholes, caves, and springs) that transport surface water through solution-enlarged joints and fractures (Imes, 1989). More than 500 explored caves are in McDonald County (Missouri Watershed Information Network, 2006). Karst topography greatly affects water quantity and quality because water and any associated contaminants can travel a great distance quickly through joints and fractures.

Although the Elk River Basin encompasses parts of three states and several counties in those states, the study area for this report focuses on the Upper Elk River Basin and, specifically, McDonald County, Missouri. Patterson Creek is a tributary to Buffalo Creek, but Buffalo Creek flows into the Elk River in Oklahoma, downstream from the sampling site on the Elk River near Tiff City. Any data collected from these streams will not be discussed in this report. Monthly waterquality samples from Big Sugar Creek, Little Sugar Creek, Indian Creek, and the Elk River were collected in McDonald County. Although most of the samples from the seepage runs were collected in McDonald County, some were collected in Barry and Newton Counties, Missouri, and Benton County, Arkansas.

The annual mean discharge of the Elk River near Tiff City was 822 cubic feet per second $\left(\mathrm{ft}^{3} / \mathrm{s}\right)$ from 1939 through October 2005 (Hauck and Harris, 2006). The annual mean discharge for water years 2005 (October 2004 through September 2005) and 2006 (October 2005 through September 2006) for the Elk River and its major tributaries is shown in table 1. The annual mean discharge for water year 2006 at each site was less than 30 percent of the annual mean discharge for water year 2005 .

A general trend of declining discharge at the Elk River near Tiff City from 1996 through September 2006 is apparent from the boxplots of the daily mean discharge shown in figure 2. Also apparent is the decrease in discharge at this location from the decade of the 1990s to the 2000s based on the daily mean discharge.

The Elk River Basin has a temperate climate, with average annual precipitation of 44.6 inches per year (in./ yr) from 1999 through 2001 (Missouri Department of Natural Resources, 1998). In 2005, the annual precipitation at Anderson was 32.59 inches (in.; National Oceanic and Atmospheric Administration, 2005). Average monthly precipitation generally is greatest in the spring [April through June; about 4 to 5 inches per month (in./mo)] and least in the late fall and winter (December through January; about 2 to 3 in./mo; National Oceanic and Atmospheric Administration, 2004-2006). Monthly precipitation at Anderson from October 2004 through November 2006 generally was less than normal (National Oceanic and Atmospheric Administration, 20042006; fig. 3).

Much of southern Missouri, including that part of the Upper Elk River Basin in the State, experienced a drought that began in late 1999 (National Drought Mitigation Center, 2007). Monthly and cumulative departure from normal precipitation from January 1999 through September 2006 for Anderson, Missouri (National Oceanic and Atmospheric Administration, 1999-2006), are shown in figure 3. In 1999, there was an excess of precipitation when compared to normal monthly quantities. From 2000 through summer 2002, the cumulative precipitation fluctuated, but generally ranged from 5 in. less than normal to about 4 in. greater than normal; however, from summer 2002, cumulative precipitation was less than normal for every month. In March 2006, the cumulative precipitation was more than 17 in. below normal.

Land use in the Elk River Basin is divided equally between forest and pasture (fig. 4). Historically, land use was 60 percent forest, 35 percent woodlands, glades, and savannas, and 5 percent prairie. Currently (2007), much of the land has been converted for use as pasture for cattle and confined animal feeding operations (Missouri Watershed Information Network, 2006).

Confined animal feeding operations in McDonald County account for the second largest concentration of poultry in Missouri, with an estimated 6 million broilers and other meat-type chickens, about 186,000 turkeys, and 157 poultry farms in 2002, down from about 7.7 million broilers and other meattype chickens, 292,000 turkeys, and 161 poultry farms in 1997 (U.S. Department of Agriculture, 2006). Poultry operations are located throughout the county, but within the Upper Elk River Basin, most are in the Indian Creek Basin (fig. 4). In McDonald County, 25 poultry operating permits were issued by the Missouri Department of Natural Resources (Missouri Department of Natural Resources, 2007). However, not all

Table 1. Water-quality sampling sites and annual mean discharge within the Upper Elk River Basin, Missouri, 2004-06.

[d, degree; m, minute; s, second; $\mathrm{mi}^{2}$, square mile; ft³/s, cubic feet per second; water year 2005, October 2004 through September 2005; water year 2006, October 2005 through September 2006; --, no data available]

\begin{tabular}{|c|c|c|c|c|c|c|c|}
\hline $\begin{array}{c}\text { Site location } \\
\text { (fig. 1) }\end{array}$ & $\begin{array}{c}\text { Site } \\
\text { number }\end{array}$ & $\begin{array}{l}\text { Latitude } \\
\text { (ddmmss) }\end{array}$ & $\begin{array}{l}\text { Longitude } \\
\text { (dddmmss) }\end{array}$ & $\begin{array}{c}\text { Basin size } \\
\left(\mathrm{mi}^{2}\right)\end{array}$ & Date of operation & \multicolumn{2}{|c|}{$\begin{array}{c}\text { Annual mean discharge } \\
\left(\mathrm{ft}^{3} / \mathrm{s}\right)\end{array}$} \\
\hline Big Sugar Creek near Powell & 07188653 & 363657 & 0941506 & 141 & May 2000 to present & 138 & 33 \\
\hline Little Sugar Creek below Caverna & 07188824 & 363143 & 0941715 & 152 & October 2004 to present & -- & -- \\
\hline Little Sugar Creek near Pineville & 07188838 & 363502 & 0942223 & 195 & October 2004 to present & 219 & 63 \\
\hline Indian Creek near Lanagan & 07188885 & 363557 & 0942659 & 239 & May 2000 to present & 250 & 66 \\
\hline
\end{tabular}




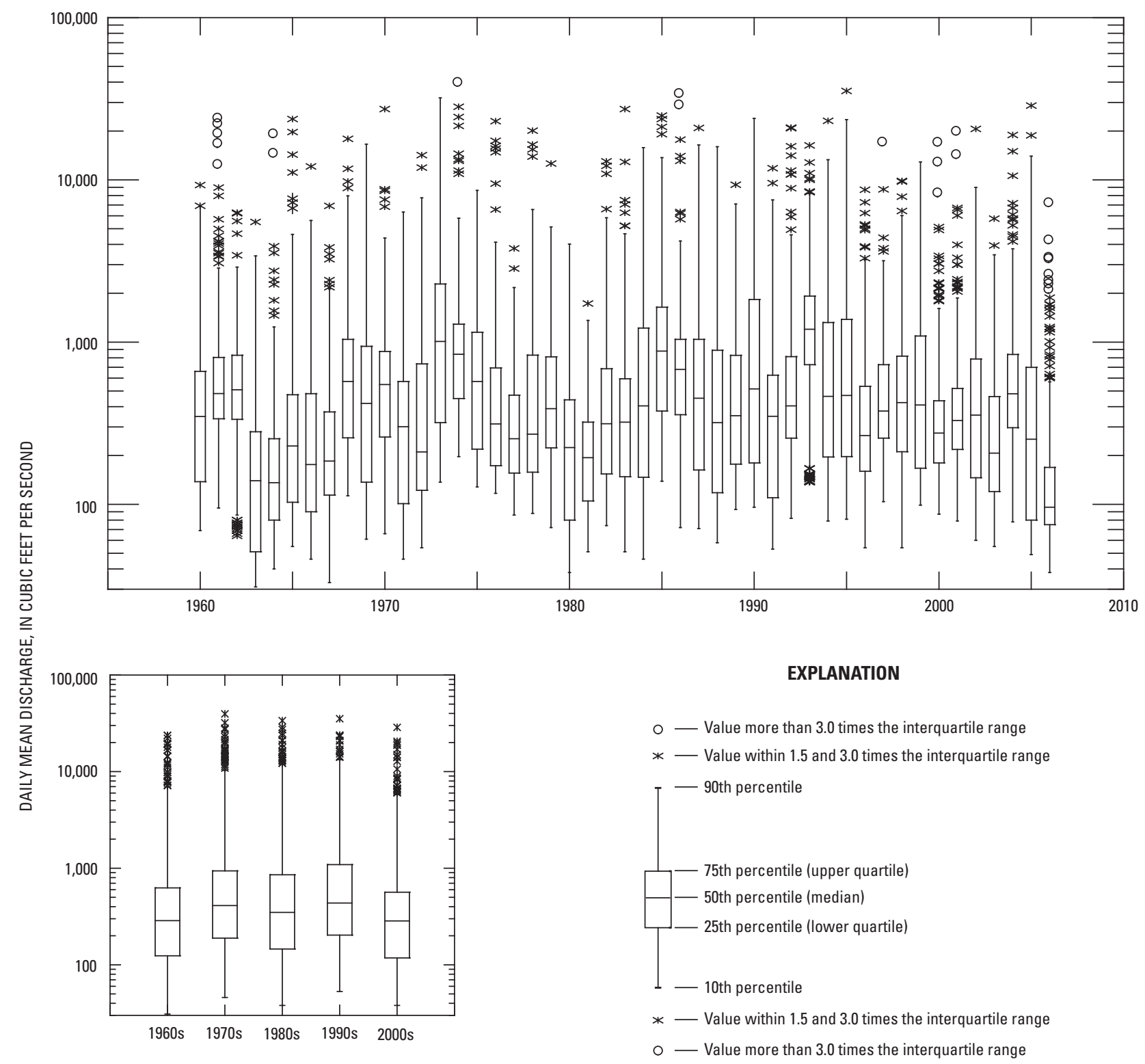

Figure 2. Discharge at the Elk River near Tiff City, 1960 through September 2006. 

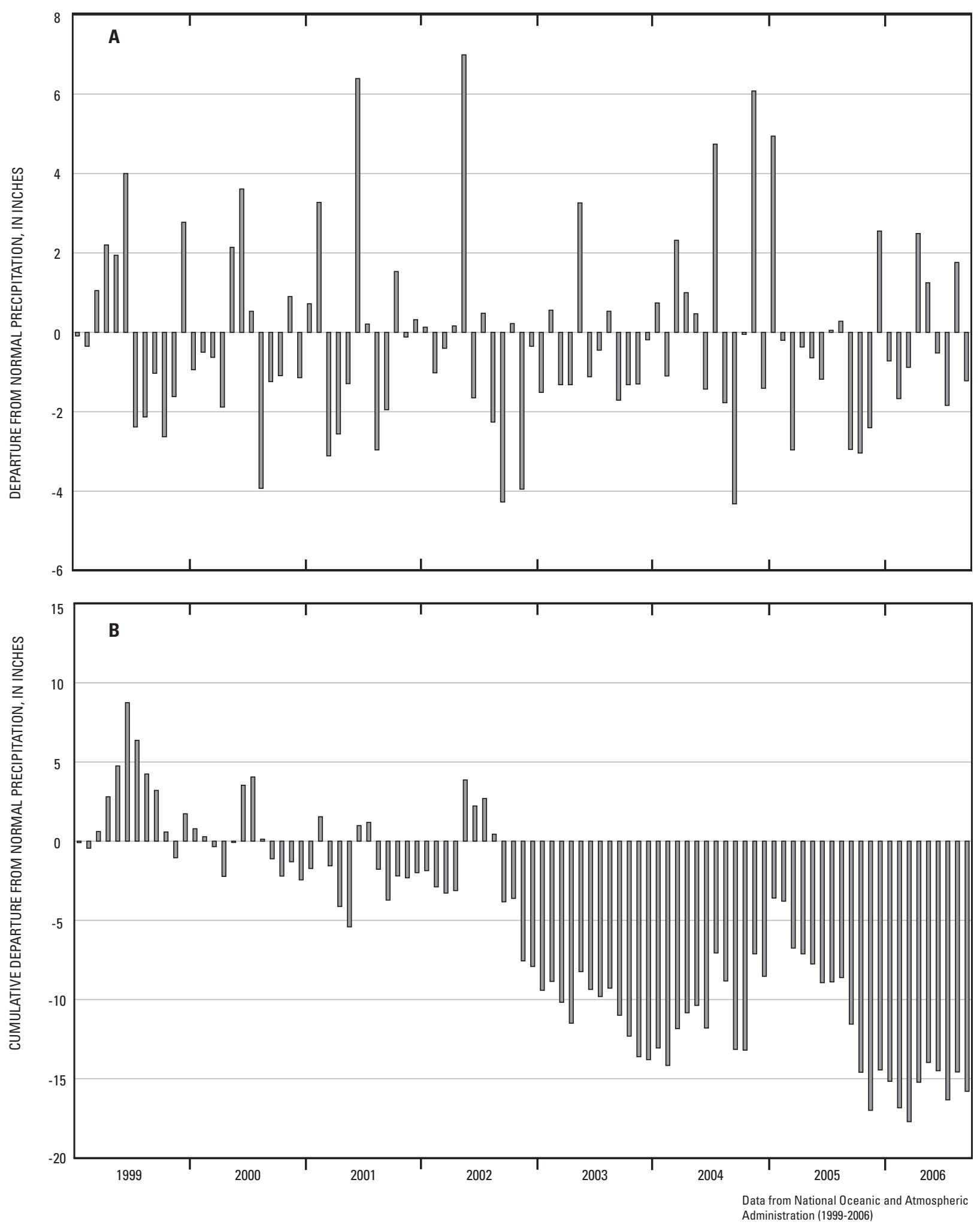

Figure 3. Monthly (A) and cumulative (B) departure from normal precipitation at Anderson, Missouri, January 1999 through September 2006. 


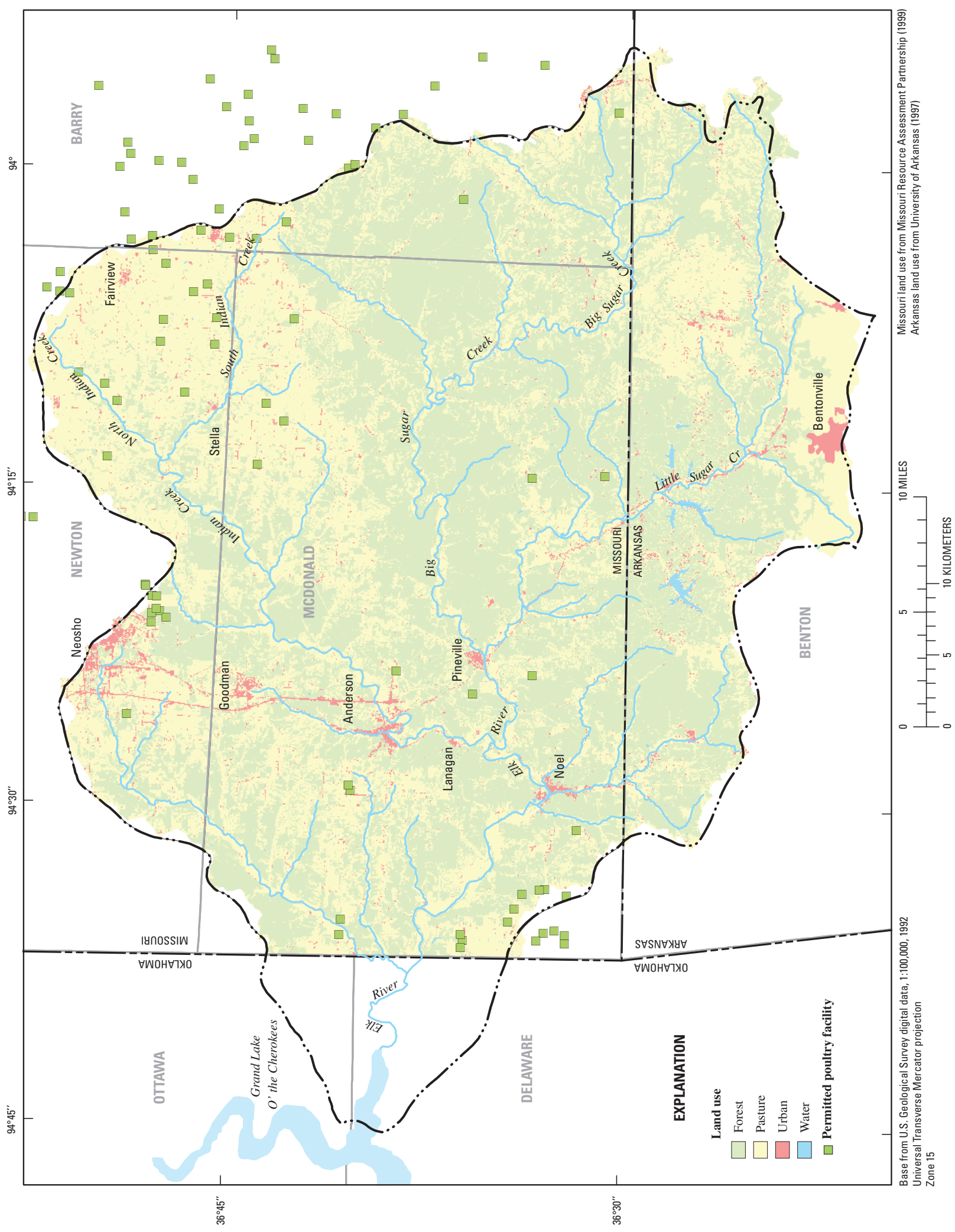

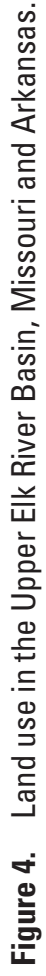


poultry operations require a permit. An estimated 700 barns are in McDonald County; each barn holds about 25,000 broilers with 5 to 6 flocks raised per year. Poultry waste is applied directly to the land surface as fertilizer (Lynn Jenkins, Natural Resources Conservation Service, oral commun., 2007).

In 2004 and 2005, more than 35,000 acres were harvested for hay in McDonald County. From 1986 through 2006, the number of cattle ranged from 58,900 (1997) to 49,500 (2004 and 2005) in McDonald County (U.S. Department of Agriculture, 2006). From 1986 through 2001, there were more than 40,000 head of swine in McDonald County. The number of swine decreased dramatically in 2002 and 2003 to less than 15,000 head. No data for swine were available for 2004 through 2006 (U.S. Department of Agriculture, 2006).

The population in McDonald County in 2005 is estimated at 22,844, an increase of 35 percent since 1990 (Indiana Business Research Center, 2006). Population estimates for 2005 for selected communities in McDonald County are: Anderson, 1,902; Goodman, 1,233; Lanagan, 453; Noel, 1,515; and Pineville, 868 (Missouri Census Data Center, 2006). The population for Neosho, Missouri (10,505), Bella Vista, Arkansas (16,582), and Bentonville, Arkansas (21,906), are from 2000 data (City-Data.com, 2007). Benton County, Arkansas, is the fastest growing county in Arkansas with a 21 percent population increase in the 5 years preceding March 2006 (Greg Hoggatt, written commun., 2007). The 2005 population for Bentonville has increased by 23.6 percent to 27,077 in July 2006 (City-Data.com, 2007).

The State of Missouri issues operating permits for sewage and agricultural processing effluents under the authority of the National Pollution Discharge Elimination System (NPDES). Permits have been issued for the following facilities (receiving stream and discharge): city of Anderson (Indian Creek, $0.3 \mathrm{ft}^{3} / \mathrm{s}$ ), city of Lanagan Housing Authority (tributary to Indian Creek, $0.003 \mathrm{ft}^{3} / \mathrm{s}$ ), city of Lanagan Housing Authority \#2 (Indian Creek, $0.003 \mathrm{ft}^{3} / \mathrm{s}$ ), city of Noel (Elk River, 0.31 $\mathrm{ft}^{3} / \mathrm{s}$ ), city of Pineville (Elk River, $0.192 \mathrm{ft}^{3} / \mathrm{s}$ ), village of Stella (South Indian Creek, $0.053 \mathrm{ft}^{3} / \mathrm{s}$ ) and two poultry facilities (Elk River, $3.6 \mathrm{ft}^{3} / \mathrm{s}$; and Little Sugar Creek, stormwater runoff) (Missouri Department of Natural Resources, 2007). Little Sugar Creek also is the receiving stream for effluent from Bella Vista $\left(0.618 \mathrm{ft}^{3} / \mathrm{s}\right)$. Effluent from Bentonville $\left(5.86 \mathrm{ft}^{3} / \mathrm{s}\right)$ discharges into Town Branch, which flows into a tributary of Little Sugar Creek, then into Little Sugar Creek. Effluent from Sulphur Springs, Arkansas $\left(0.155 \mathrm{ft}^{3} / \mathrm{s}\right)$, discharges into a tributary of the Elk River, then into the Elk River.

\section{Methods of Study}

To assess the water quality of the study area, a network of sampling sites throughout the Upper Elk River Basin was established. Water and streambed-sediment samples were collected from these sites and analyzed for a variety of physical properties and chemical constituents during different streamflow conditions. This report includes analyses of water and streambed-sediment samples collected from October 2004 through December 2006.

\section{Sample Collection and Analysis Methods}

Monthly water-quality samples were collected from six sites within the Upper Elk River Basin upstream from Tiff City from October 2004 through September 2006. These sites (USGS streamflow-gaging station number is shown in parentheses) included Big Sugar Creek near Powell (07188653), Big Sugar Creek near Pineville (07188760), Little Sugar Creek below Caverna (07188824), Little Sugar Creek near Pineville (07188838), Indian Creek near Lanagan (07188885), and the Elk River near Tiff City (07189000; fig. 1, table 1). Samples for nutrient analyses (dissolved ammonia, nitrite, nitrite plus nitrate, and orthophosphorus and total ammonia plus organic nitrogen and total phosphorus) were collected according to standard USGS sample collection and processing protocols described by Edwards and Glysson (1998) and Wilde and others (1999a, 1999b). All chemical analyses were done by the USGS National Water Quality Laboratory (NWQL) in Lakewood, Colorado, according to procedures described in Fishman and Friedman (1989) or Fishman (1993). Onsite measurements of dissolved oxygen, $\mathrm{pH}$, specific conductance, and water temperature were made at each site according to procedures described by Wilde and Radtke (1998). Samples were collected and analyzed by the USGS at each site for indicator bacteria [fecal coliform and Escherichia coli (E. coli)] using the membrane filtration procedure described in Myers and Wilde (1997). Individual bacteria samples were collected in sterile $500-\mathrm{mL}$ (milliliter) polypropylene bottles by facing the bottle into the stream current and dipping quickly into the stream at three to five equally spaced locations in the stream cross section. The samples were placed on ice and held a maximum of 6 hours until processing. Because densities of indicator bacteria can be quite variable, generally two sample volumes ranging from 10 to $100 \mathrm{~mL}$ were filtered from individual stream samples. Reagent blanks were run twice each day to check for contamination of equipment and reagents.

A continuous streamflow-gaging station was installed at three of the sites-Big Sugar Creek near Powell (May 2000), Little Sugar Creek near Pineville (October 2004), and Indian Creek near Lanagan (May 2000). A long-term gaging station has been operational at the Elk River near Tiff City since October 1939. Continuous stream-stage (water-surface elevation) data were collected at these sites using a vented submersible pressure transducer. Streamflow measurements were used to establish and maintain the relation between stage and discharge (Rantz and others, 1982).

Stormwater samples were obtained at the four gaged sites of Big Sugar Creek near Powell, Little Sugar Creek near Pineville, Indian Creek near Lanagan, and the Elk River near Tiff City using either automatic samplers programmed to collect samples after stage thresholds were exceeded, or by manual collection. Stormwater sampling generally was conducted after 72 hours of no runoff. For several storms, more than one 
site was sampled (November 2004, May 2005, April 2006, and May 2006). Sampling was initiated on the rising limb of the storm hydrograph; one or more samples were collected on the rising limb, a sample was collected at or near the peak of flow, and one or more samples were collected on the falling limb. The initial three samples after the sampler was activated were composited and sent to the NWQL for the analysis of the same constituents as for the monthly samples. The remaining samples were analyzed for the nutrients only. Indicator bacteria densities were determined from at least one sample. Also, one or more samples for nitrogen isotope analysis were collected at each site. These samples were sent to the USGS Reston Stable Isotope Laboratory in Reston, Virginia. The nitrate samples were analyzed by bacterial conversion of nitrate to nitrous oxide and subsequent measurement on a continuous flow isotope ratio mass spectrometer (Sigman and others, 2001; Casciotti and others, 2002; Coplen and others, 2004).

During the summer and fall of 2006, two seepage runs were conducted in the study area. From July 31 through August 3, discharge measurements were made at more than 70 sites, and water-quality samples were collected at about 50 sites throughout the Upper Elk River Basin (see 'Seepage Run Water Quality' section). On November 13 and 14, the seepage run was repeated at eight of the sites from the previous seepage run. Discharge measurements were made in accordance with standard USGS procedures (Rantz and others, 1982). Water-quality samples were analyzed for a similar suite of constituents, as were the monthly samples. Samples also were collected for the determination of optical brighteners and chlorophyll $a$. Analysis of these samples was conducted in the USGS laboratory in Rolla, Missouri, using a spectrofluorophotometer and fluorometer. Selected samples were analyzed for wastewater indicator compounds and pharmaceutical compounds. Wastewater indicator compounds were determined from filtered samples by continuous liquid-liquid extraction with methylene chloride and determined by capillary-column gas chromatography/mass spectrometry using selected-ion monitoring (Brown and others, 1999; Kolpin and others, 2002) at the NWQL. Information in Zaugg and others (2001) provides details about specific wastewater indicator compounds and their uses. Pharmaceutical compounds were determined from filtered samples by high-performance liquid chromatography/electrospray ionization-mass spectrometry analysis (Furlong and others, 2000; Kolpin and others, 2002) at the NWQL.

Quality-assurance samples were collected and analyzed to ensure the integrity of the water-quality data. About 10 percent of all samples collected were blank or replicate qualityassurance samples.

The adequacy of the field cleaning and sample processing protocols were evaluated through field equipment blank samples. Purified water (blank water) was passed through the same equipment used to collect and process water-quality samples and then stored, shipped, and analyzed by NWQL using identical methods that were used for environmental samples. A blank sample was prepared by the NWQL and analyzed with environmental samples to ensure that laboratory contamination was not a concern during analyses. Measurable concentrations in blank water can result from trace quantities of constituents in the water, as well as residual material in sample processing or analytical equipment. Most compounds were not detected in any blank samples; if detected, the reported concentrations were near the detection limit for these compounds (data on file at the U.S. Geological Survey office, Rolla, Missouri). The blank sample data support the conclusion that equipment cleaning, sample collection, and processing procedures provided an inconsequential source of bias to environmental samples.

Replicate samples were collected to determine the variability in sample collection and processing procedures and to examine the effect these variations may have on concentrations determined from environmental samples. Generally, a replicate sample was collected immediately after an environmental sample using the same equipment and sampling techniques. The environmental and replicate samples were analyzed at the NWQL using identical analytical techniques. Analysis of replicate samples indicated that the laboratory analysis and the sampling procedure were producing consistent results. Results of the environmental and replicate sample analyses generally were within 5 percent of each other.

A total of 35 streambed-sediment samples were collected from the Upper Elk River Basin in August 2005 to examine geographic differences in sediment composition (see 'Streambed-Sediment Quality' section). Samples were collected using a small plastic scoop in areas where fine-grained sediment accumulated (for example, behind large rocks, woody debris, and bridge piers). Several subsamples were collected at each site. Fine-grained sediment was sampled to target material that could be mobilized easily during storm flow. Subsamples were composited into two split samples (split A and B) in polyethylene containers and transported to the USGS office in Rolla, Missouri. Sample split A was shipped to the USGS Geochemistry Laboratory in Denver, Colorado, for grain-size (percent sand, silt, and clay) and chemical analysis of the less than 63-micrometer $(\mu \mathrm{m})$ size fraction using Inductively Coupled Plasma/Mass Spectrometry (ICP/MS). Sample split $\mathrm{B}$ was leached with deionized water in an effort to estimate the quantity of nutrients readily leachable from the sediment. Split B samples were prepared by air drying the sample overnight and sieving through a 2-millimeter (mm) mesh stainless steel screen. Approximately 22 grams (g) of sieved sediment sample were placed into a clean polyethylene bottle with $220 \mathrm{~mL}$ of deionized water. The bottles were shaken for 10 minutes and allowed to settle for 2 hours. After settling, the supernatant was filtered through a $0.45-\mu \mathrm{m}$ pore-size filter into clean polyethylene bottles and shipped overnight on ice for nutrient analysis at the NWQL.

\section{Data Analysis Methods}

Statistical analyses were conducted by comparing waterquality characteristics between sites and between ambient and 
stormwater samples at individual sampling sites. Nonparametric statistical methods were used to analyze data when appropriate because water-quality data generally are not normally distributed, and the data often contain values less than the method detection limit (censored data). Nonparametric statistical methods were used because these methods are not unduly affected by extreme data values (outliers) and because ranks of data are used instead of the actual concentrations of the waterquality constituents. A significance level $(\alpha)$ of 0.05 was used for statistical tests for water-quality samples. A significance level $(\alpha)$ of 0.10 was used for statistical tests for streambedsediment samples. The higher level of 0.10 was used for the sediment samples because of the lack of reproducibility of the results caused by the inhomogeneity of the samples. The attained significance level, or probability of error ( $p$-value) from the test, often was much lower and is reported to provide a quantitative indication of the degree of similarity or difference between data sets.

The nonparametric statistical methods included the Kruskal-Wallis test and multiple comparison tests on the data ranks (Helsel and Hirsch, 1992). The Kruskal-Wallis test is an analysis of variance on the ranks of data that test for differences in the central tendency, or medians, of two or more groups. When the Kruskal-Wallis test indicated a significant difference at the 0.05 level for water-quality samples and at the 0.10 level for sediment samples, a t-test on the ranks (Tukey's $\mathrm{W})$ was performed on each paired group to evaluate which groups were statistically different from one another.

Selected nutrient loads were estimated with the USGS software LOADEST as part of the S-Plus software program (Insightful Corporation, 2005). LOADEST uses time-series streamflow data and constituent concentrations to calibrate a regression model that describes constituent loads in terms of various functions of streamflow and time (Runkel and others, 2004). A complete discussion of the theory and principles behind the calibration and estimation methods is presented in Runkel and others (2004). The LOADEST software allows the user to choose between selecting the general form of the regression from several predefined models and letting the software automatically select the best-defined model on the basis of the Akaike Information Criterion (AIC) (Akaike, 1981). The model that the software selected was used for this study.

The output regression equations have the following general form:

$\ln (L)=a+b(\ln Q)+\mathrm{c}\left(1 n Q^{2}\right)+d[\sin (2 \pi T)]+e[\cos (2 \pi T)]+f T+g T^{2}$

where $L$ is the constituent load, in tons per day;

$Q \quad$ is the stream discharge, in cubic feet per second;

$T$ is the time, in decimal years, from the beginning of the calibration period; and

$a, b, c, d, e, f, g \quad$ are regression coefficients.

The distribution of selected physical property values or constituent concentrations at sampling sites is shown using side-by-side boxplots (Tukey, 1977). A boxplot is a useful tool for visually examining the central tendency and dispersion of a group of data or for comparing two or more groups of data. To construct a boxplot, the median value is plotted as a horizontal line, and a box is drawn from the $25^{\text {th }}$ percentile to the $75^{\text {th }}$ percentile. The box length equals the interquartile range (IQR). Vertical lines are then drawn from the quartiles to two "adjacent" values. The upper adjacent value is defined as the largest data point less than or equal to the upper quartile plus 1.5 times the IQR $\left(90^{\text {th }}\right.$ percentile). The lower adjacent value is the smallest data point greater than or equal to the lower quartile minus 1.5 times the IQR $\left(10^{\text {th }}\right.$ percentile $)$. Values more extreme in either direction than the adjacent values are plotted individually. Those values equal to 1.5 to 3.0 times the IQR are called "outside values" and generally are represented by an asterisk; those values greater than 3.0 times the IQR are called "far-out values" and generally are represented by a circle (Davis and Schumacher, 1992).

For streambed-sediment samples, a linear regression was used to analyze the relation between a dependent concentration and an independent concentration. Graphs showing the relation of streambed-sediment concentrations have the linear trend plotted along with the confidence interval. The confidence interval specifies the range that contains most of the streambed-sediment concentrations-for example, the upper confidence level of 95 percent and the lower level of 5 percent were plotted.

\section{Water Quality}

\section{Historical Water Quality}

The USGS has collected water-quality data from several sites throughout the Upper Elk River Basin (fig. 1). Data collected before October 2004 have been included in the historical data category. Data were collected for Mikes Creek at Powell (07188660) and North Indian Creek near Wanda (07188855) during 1994 and 1995, Little Sugar Creek at Caverna (07188820) from 1964 through 1983, and the Elk River near Tiff City from 1960 through 2004. Samples collected from Little Sugar Creek at Caverna were collected at a site about 2 miles (mi) upstream from the site of the monthly water-quality sample collection at Little Sugar Creek below Caverna (07188824).

The following discussion about constituent concentrations and analysis will be limited to the sampling sites at Little Sugar Creek at Caverna and the Elk River near Tiff City because of the extremely small sample size at Mikes Creek at Powell and North Indian Creek near Wanda. The discussion also will be confined to the period of overlapping sample collection (August 1964 through September 1983) at Little Sugar Creek and the Elk River. However, the boxplots in the following figures will show samples from all sites that have historical data. 
Sodium and chloride concentrations in historical samples from Little Sugar Creek at Caverna were significantly larger $(\mathrm{p}<0.01)$ than those concentrations from the Elk River near Tiff City (fig. 5). Sulfate concentrations at the two sites were similar $(\mathrm{p}=0.269)$. The increased concentrations of sodium and chloride at Little Sugar Creek at Caverna possibly indicate effects from wastewater effluent discharged into the creek.

The constituents of concern in the Upper Elk River Basin are nutrients; therefore, the following discussion will be limited to analysis of dissolved nitrate as nitrogen (nitrate), total nitrogen, and total phosphorus concentrations. The nitrate concentrations were expressed in several ways: concentrations of nitrate (not as nitrogen) were multiplied by an appropriate conversion factor to determine a nitrate concentration as nitrogen; concentrations of nitrate as nitrogen were used as is; and nitrite plus nitrate concentrations were assumed to equal nitrate concentrations because concentrations of nitrite were small [less than 0.01 milligram per liter $(\mathrm{mg} / \mathrm{L})]$. Total nitrogen concentrations were calculated by summing the concentrations of total ammonia plus organic nitrogen and nitrite plus nitrate.

The total nitrogen concentrations within the Upper Elk River Basin generally were comprised of 80 percent or more nitrate (fig. 6). Hereinafter, only nitrate concentrations will be discussed. The distribution of nutrient species in historical samples is shown in figure 6. The nitrate concentrations were statistically larger in samples from Little Sugar Creek at Caverna $(p<0.01)$ than those in samples from the Elk River near Tiff City during the period of overlapping sample collection.

Total phosphorus concentrations generally were less than $0.70 \mathrm{mg} / \mathrm{L}$ for all sites within the basin (fig. 6). Concentrations in samples from Little Sugar Creek at Caverna were significantly larger than those in samples from the Elk River near Tiff City $(\mathrm{p}<0.01)$. The median total phosphorus concentration was $0.20 \mathrm{mg} / \mathrm{L}$ in samples from Little Sugar Creek at Caverna.
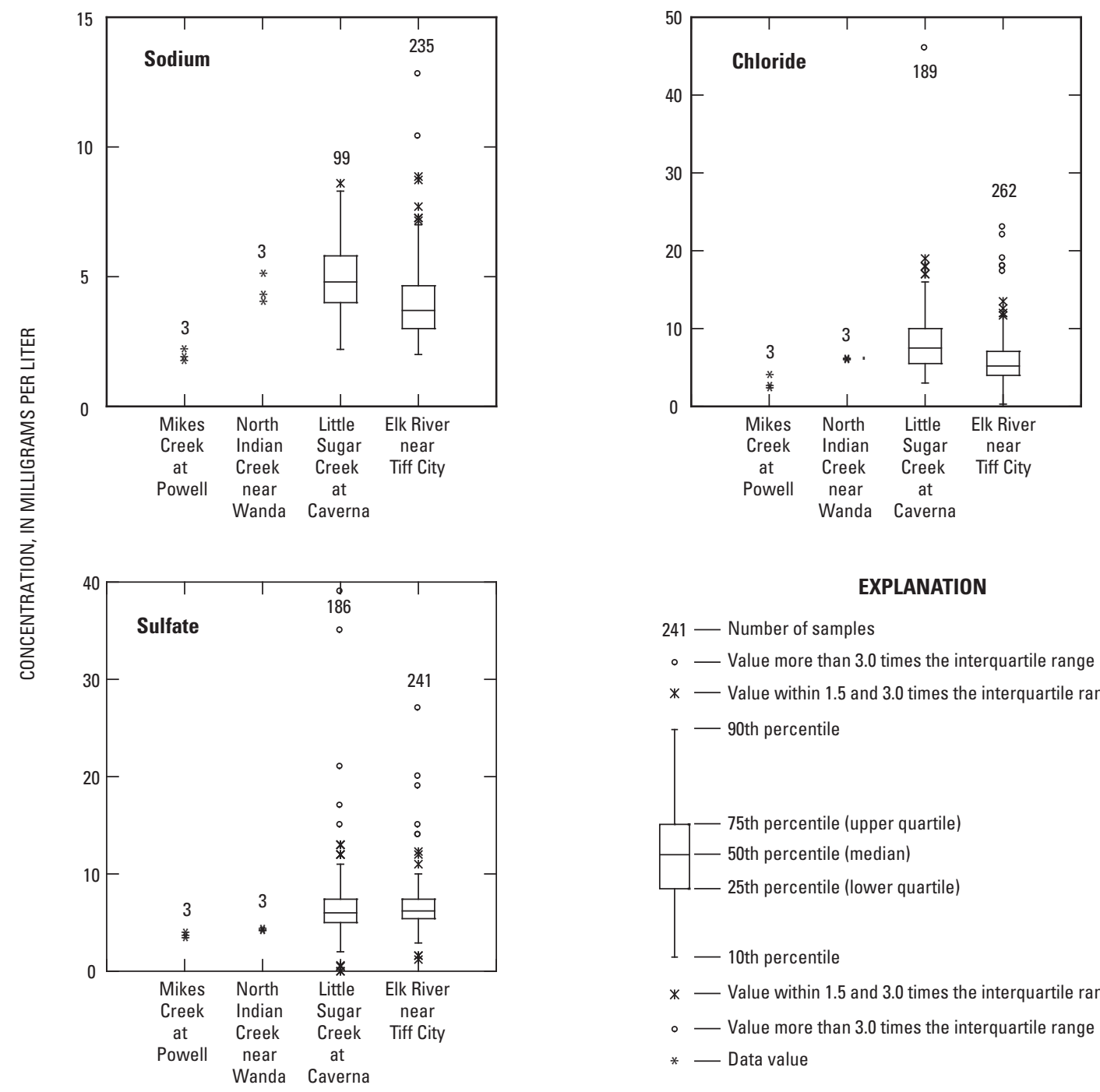

\section{EXPLANATION}

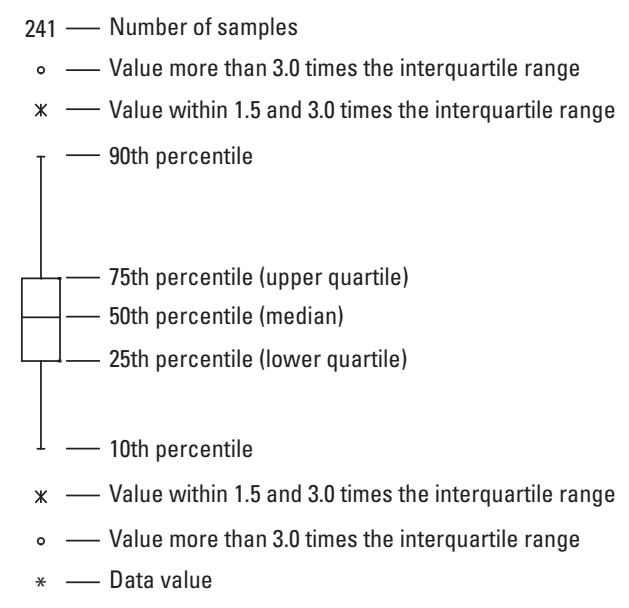

Figure 5. The distribution of selected major ion concentrations in historical water-quality samples within the Upper Elk River Basin. 

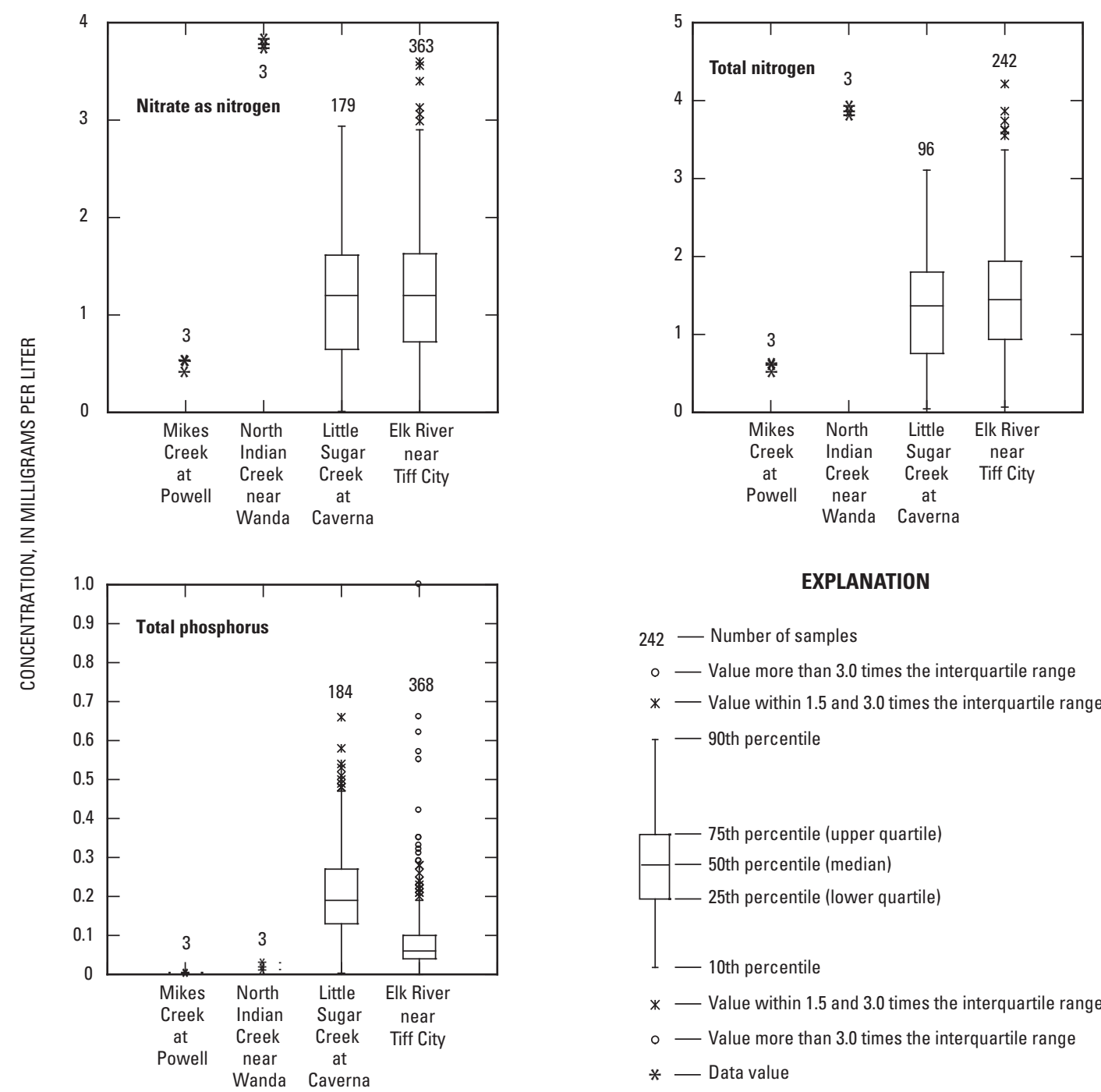

\section{EXPLANATION}

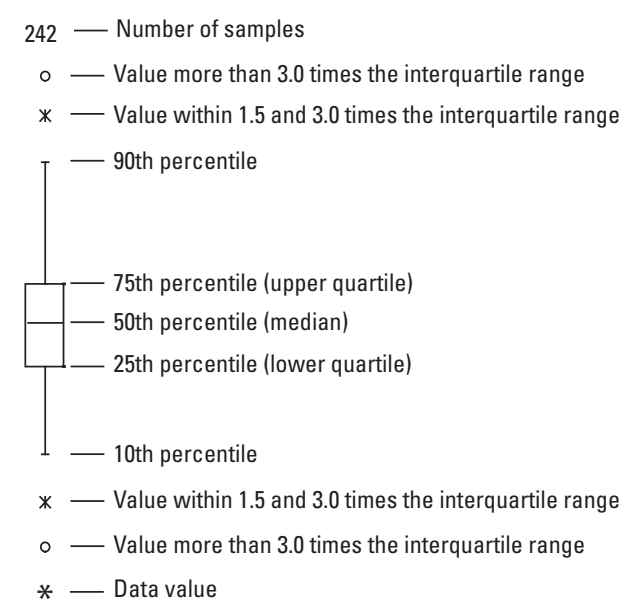

Figure 6. The distribution of nutrient concentrations in historical water-quality samples within the Upper Elk River Basin.

Discharge and water-quality data from the Elk River near Tiff City from 1966 through 2002 were used for a trend analysis by the Missouri Department of Natural Resources as a basis for including the Elk River on its 303(d) list. The total phosphorus concentrations for 1966 through 1984 were statistically different from the concentrations for 1985 through 2002 $(\mathrm{p}<0.01)$. The mean total phosphorus concentration before 1985 was $0.064 \mathrm{mg} / \mathrm{L}$ and after 1985 was $0.094 \mathrm{mg} / \mathrm{L}$ (Missouri Department of Natural Resources, 2004). Throughout the Upper Elk River Basin in Missouri, which has about one-third of the number of poultry in the entire basin, the yearly average number of poultry increased by 189 percent since 1985 when compared to the number before 1985 . The increase is based on the yearly averages of 1974, 1978, 1982, 1987, 1992, and 1997. The number of hogs and cattle declined slightly for the same period (Missouri Department of Natural Resources, 2004).
With the addition of samples from 2003 through September 2004, the concentrations of total phosphorus in post-1985 samples from the Elk River near Tiff City also were significantly larger $(\mathrm{p}<0.01$; fig. 7$)$ than the concentrations in the pre-1985 samples. The mean before 1985 was 0.064 ; after 1985 , it was $0.093 \mathrm{mg} / \mathrm{L}$.

The total phosphorus concentrations have increased in historical samples from the Elk River near Tiff City during periods from 1962 through September 2004 (fig. 8). The last increase occurred from 2000 through 2003. The total phosphorus distribution by decade indicates that the concentrations since 2000 have increased significantly $(\mathrm{p}<0.01)$ from those in the 1960s, 1980s, and 1990s (fig. 8).

Although nitrate concentrations were not referred to in the Missouri Department of Natural Resources (2004), these concentrations also have significantly increased in post-1985 samples from pre-1985 samples in the Elk River near Tiff City 

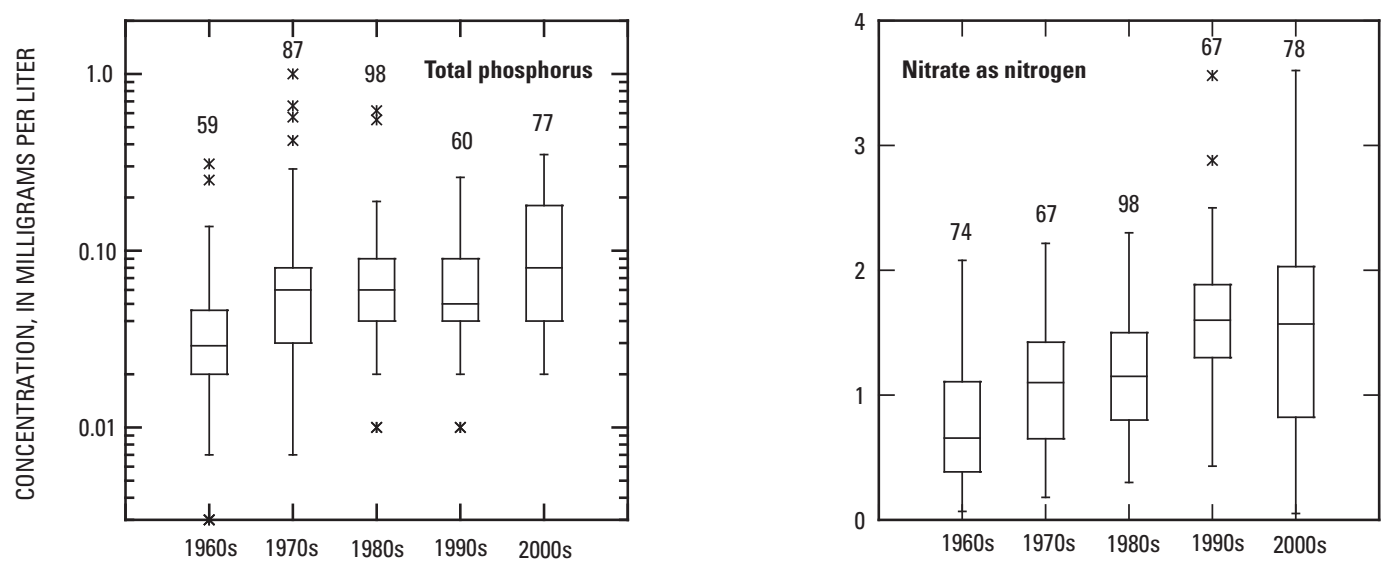

EXPLANATION

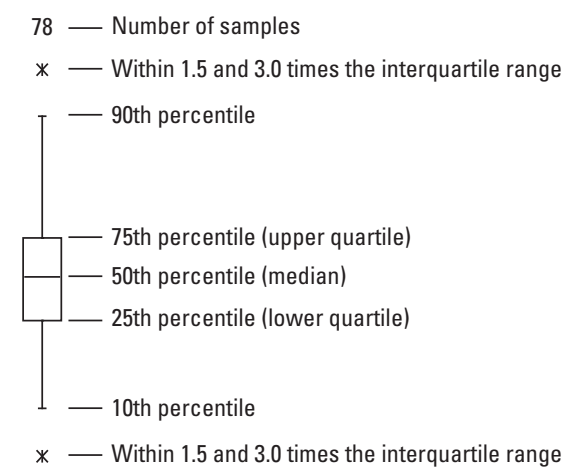

Figure 7. Distribution of total phosphorus and nitrate as nitrogen concentrations, by decades, in samples from the Elk River near Tiff City.

(fig. 7). Median nitrate concentrations increased from 0.880 $\mathrm{mg} / \mathrm{L}$ before 1985 to $1.44 \mathrm{mg} / \mathrm{L}$ after 1985 .

The distribution of nitrate at Elk River near Tiff City indicates a slight upward trend with time; however, when the data are grouped by decade, the trend becomes more apparent (fig. 9). Concentrations have increased significantly since the 1960s. Concentrations in the 1970s and 1980s, though similar, had increased from those in the 1960s, and the concentrations from the 1990s and 2000s increased still more.

Nitrate concentrations significantly $(\mathrm{p}<0.01)$ increased in samples that were collected during larger discharges from the Elk River near Tiff City as compared to the concentrations in samples collected during smaller discharges (fig. 10). The discharge used was $355 \mathrm{ft}^{3} / \mathrm{s}$, which was the discharge that was exceeded 50 percent of the time. Not only are nitrate concentrations increasing as discharge increases, the concentrations are increasing during the period of sample collection. However, nitrate concentrations in samples collected at discharges less than $355 \mathrm{ft}^{3} / \mathrm{s}$ decreased from the late 1990s when discharge began to decrease (fig. 2). The increased nitrate concentrations possibly can be attributed to runoff from nonpoint sources.

\section{Ambient Water Quality}

Water-quality samples were collected monthly from October 2004 through September 2006 from six sites within the Upper Elk River Basin (fig. 1). These sites were Big Sugar Creek near Powell, Big Sugar Creek near Pineville, Little Sugar Creek below Caverna, Little Sugar Creek near Pineville, Indian Creek near Lanagan, and the Elk River near Tiff City. Whenever possible, samples were collected synoptically at these sites, meaning as close in time as possible, with no intervening rainfall during sample collection. Summary statistics for selected physical properties, inorganic constituents, and nutrients are listed in table 2.

Stream samples were calcium-bicarbonate type waters (fig. 11). The samples plot within a small area near the calcium and bicarbonate vertices. Samples from Little Sugar Creek below Caverna and the Elk River near Tiff City indicate minor variations that plot along a line trending toward decreasing calcium and increasing chloride values, indicating possible mixtures of effluent from wastewater treatment plants.

The specific conductance values throughout the upper Elk River Basin ranged from 200 to 350 microsiemens per centi- 


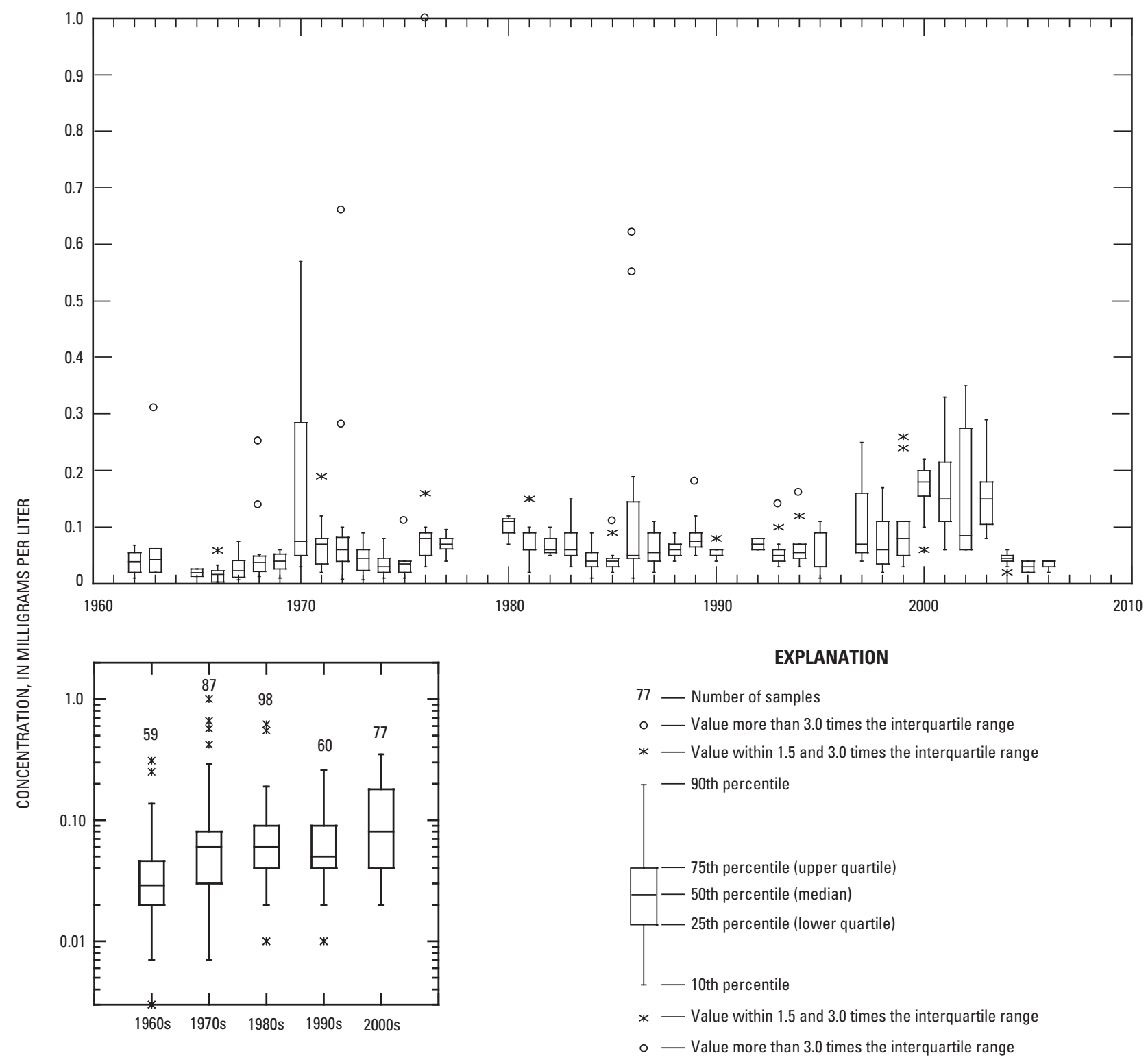

Figure 8. The distribution of total phosphorus concentrations in samples from the Elk River near Tiff City, 1962-2006.

menter at $25^{\circ} \mathrm{Celsius}(\mu \mathrm{S} / \mathrm{cm})$ at the ambient sampling sites (median values less than $300 \mu \mathrm{S} / \mathrm{cm}$ ) except for the sites on Little Sugar Creek. In the adjoining Shoal Creek Basin, much of which is in Barry County northeast of the Elk River Basin, specific conductance values generally were less than 350 $\mu \mathrm{S} / \mathrm{cm}$ (Schumacher, 2001). The Shoal Creek Basin also has a large number of livestock production facilities.

Stream samples generally had slightly alkaline $\mathrm{pH}$ values (7.0 to 8.4) and dissolved oxygen concentrations greater than $6.0 \mathrm{mg} / \mathrm{L}$. Dissolved oxygen concentrations of less than 5.0 $\mathrm{mg} / \mathrm{L}$ were measured in Big Sugar Creek near Pineville during the summer months. The Missouri Department of Natural Resources has a minimum dissolved oxygen concentration requirement for warm-water fisheries of $5 \mathrm{mg} / \mathrm{L}$. One of the beneficial uses of Big Sugar Creek is warm-water fishery (Missouri Department of Natural Resources, 2005). Dissolved oxygen concentrations are a function of temperature, waste loads, and hydraulic properties that affect the rates at which atmospheric oxygen can be supplied (Davis and Schumacher, 1992). The solubility of oxygen is greater in colder water than in warm water (Hem, 1985). No statistical difference existed in the dissolved oxygen concentrations at the sites $(\mathrm{p}=0.614)$. Effluent inflow appears to have not adversely affected the dissolved oxygen concentrations at the sampled sites.

Fecal indicator bacteria densities in ambient samples generally increased with increasing discharge. The largest densities were related to changes in discharge as a result of storms. Missouri has established water-quality criteria for fecal bacteria in streams that have a designated beneficial use of whole-body-contact recreation. Category A criteria for $E$. coli is 126 colonies per 100 milliliters $(\mathrm{col} / 100 \mathrm{~mL})$ and for fecal coliform is $200 \mathrm{col} / 100 \mathrm{~mL}$. Category A includes "public 

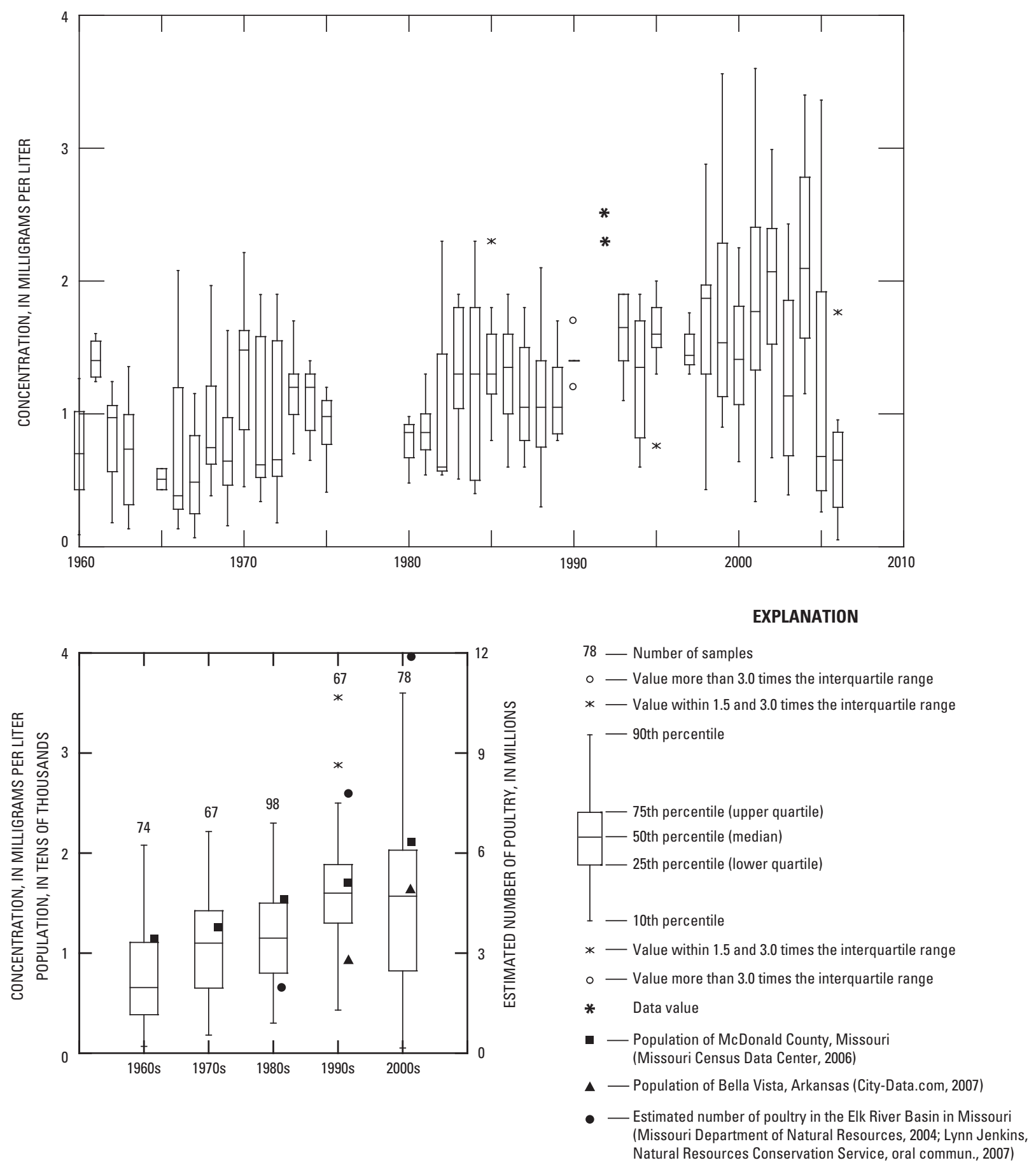

Figure 9. The distribution of nitrate as nitrogen concentrations in samples from the Elk River near Tiff City, 1960-2006.

swimming beaches and property where whole body contact recreational activity is open to and accessible by the public through law or written permission of the landowner" (Missouri Department of Natural Resources, 2005). The criteria are a monthly geometric mean during the recreation season (April 1 to October 31) in waters designated for recreation or at any time in losing streams. For ambient samples, fecal coliform and $E$. coli densities exceeded the water-quality criteria in Big Sugar Creek-twice near Powell and three times near Pineville. The criteria were exceeded two times in Little Sugar
Creek below Caverna and four times near Pineville (in August 2005 , only the E. coli criteria were exceeded); the criteria also were exceeded four times in samples from the Elk River near Tiff City. No exceedances were noted in samples from Indian Creek near Lanagan.

Nitrate concentrations were largest in Indian Creek. Several sources of nitrate are present in the basin, including poultry facilities in the upper part of the basin, effluent inflow from communities of Anderson and Lanagan, land applied animal waste, chemical fertilizer, and possible leaking septic systems. 


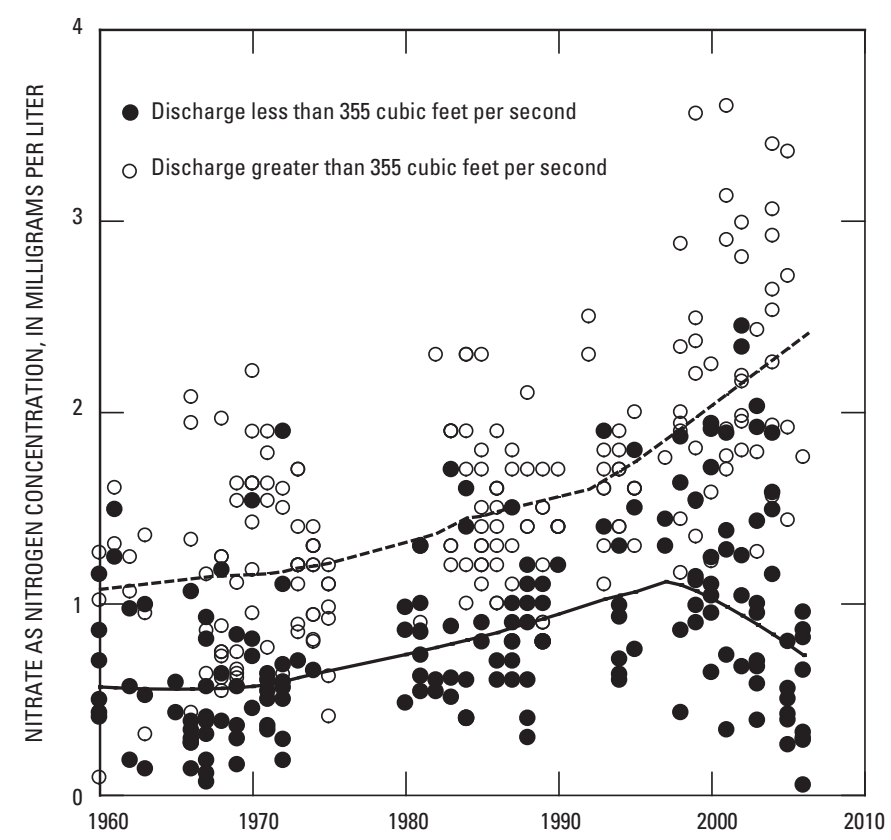

Figure 10. Relation between nitrate as nitrogen concentrations and discharge in samples from the Elk River near Tiff City, 1960 to September 2006.

Concentrations of nitrate in samples from the upstream sites for Big and Little Sugar Creeks were larger than the concentrations of nitrate in the downstream sites. Several poultry facilities present in the upper reaches of Big Sugar Creek and fertilizer applied to lawns and golf courses around Bella Vista, Arkansas, and effluent from that city possibly could provide the larger nitrate concentrations that were detected at Big Sugar Creek near Powell and Little Sugar Creek below Caverna. The nitrate concentrations in the Elk River were not significantly different from those of Big and Little Sugar Creeks. Median nitrate concentrations ranged from 0.55 (Big Sugar Creek near Pineville) to $1.7 \mathrm{mg} / \mathrm{L}$ (Indian Creek near Lanagan; table 2; fig. 12). The maximum concentration of $4.6 \mathrm{mg} / \mathrm{L}$ was detected in a sample from Indian Creek near Lanagan.

The total phosphorus concentrations were largest in Little Sugar Creek. The median concentration in samples from Little Sugar Creek below Caverna was more than eight times the median concentration in samples from the Elk River near Tiff City; the median concentration from samples from Little Sugar Creek near Pineville was almost four times the median concentration in samples from the Elk River near Tiff City (table 2; fig. 12). Median total phosphorus concentrations in samples from the Upper Elk River Basin ranged from 0.02 (Big Sugar Creek near Powell) to $0.265 \mathrm{mg} / \mathrm{L}$ (Little Sugar Creek below Caverna; table 2; fig. 12). The largest total phosphorus concentration detected in samples was $0.430 \mathrm{mg} / \mathrm{L}$ at Little Sugar Creek below Caverna. The site on Little Sugar Creek below Caverna is about 3 river miles downstream from the outfall for the wastewater treatment facility that processes wastewater for Bella Vista.
Load calculation of the various constituents is important in determining the total quantity of the constituent that passes a certain point in a given time. The constituent load at the Elk River near Tiff City is determined, in part, by the loads of the tributaries of Big Sugar, Little Sugar, and Indian Creeks that flow into the Elk River. Tributary inflow into the Elk River, using only samples where the discharge from the three tributaries was less than the discharge at the Elk River near Tiff City, was comprised of about 21 percent from Big Sugar Creek, 25 percent from Little Sugar Creek, and 29 percent from Indian Creek. Flow from these tributaries accounted for about 75 percent of the flow in the Elk River near Tiff City. Generally at discharges of less than $100 \mathrm{ft}^{3} / \mathrm{s}$, inflow from the three tributaries exceeded the discharge at the Elk River near Tiff City, indicating the presence of losing stream segments in the reach of the Elk River between the confluence of Big and Little Sugar Creeks and the gaging station near Tiff City.

In the Upper Elk River Basin, the largest monthly median nitrate load was carried by the Elk River near Tiff City (fig. 13), and the second largest by Indian Creek near Lanagan, the tributary immediately upstream from the Elk River at Tiff City. The smallest load was from Big Sugar Creek near Powell, with a corresponding increase downstream. The loads increased downstream in the basin. The total phosphorus loads were largest at Little Sugar Creek near Pineville and the Elk River near Tiff City. The median load at Little Sugar Creek near Pineville was 0.649 ton per day and at the Elk River near Tiff City was 0.719 ton per day.

Based on median monthly nutrient loads calculated from the ambient samples, Big Sugar Creek near Powell contributes 18 percent of the nitrate load at the Elk River near Tiff City. Little Sugar Creek near Pineville contributes another 31 percent, and Indian Creek near Lanagan contributes 59 percent. The total phosphorus load at the Elk River near Tiff City comprises 4 percent from Big Sugar Creek, 90 percent from Little Sugar Creek, and 29 percent from Indian Creek. If the nutrient loads at the Elk River near Tiff City were simply a total of the loads from the major tributaries, they would be much larger than those determined from the samples. Nutrients are being removed in the Elk River by processes that consume them or bind them to sediment or through stream losses. For example, the cumulative nitrate load from the three tributaries to the Elk River was 108 percent of the load calculated at the Elk River near Tiff City, and the total phosphorus load was more than 123 percent of the load calculated in samples from the Elk River near Tiff City.

Little Sugar Creek in the vicinity of Caverna is one of two locations in the study area that has substantial historical data, in addition to the ambient data. Previous data collection ended in 1983; therefore, more than 20 years have passed to the beginning of the sample collection during 2004. The nitrate concentrations from the ambient samples were significantly larger $(\mathrm{p}<0.01)$ than the concentrations in the historical samples. However, the total phosphorus concentrations between the different periods were statistically similar. Therefore, increases in human population and recreational 


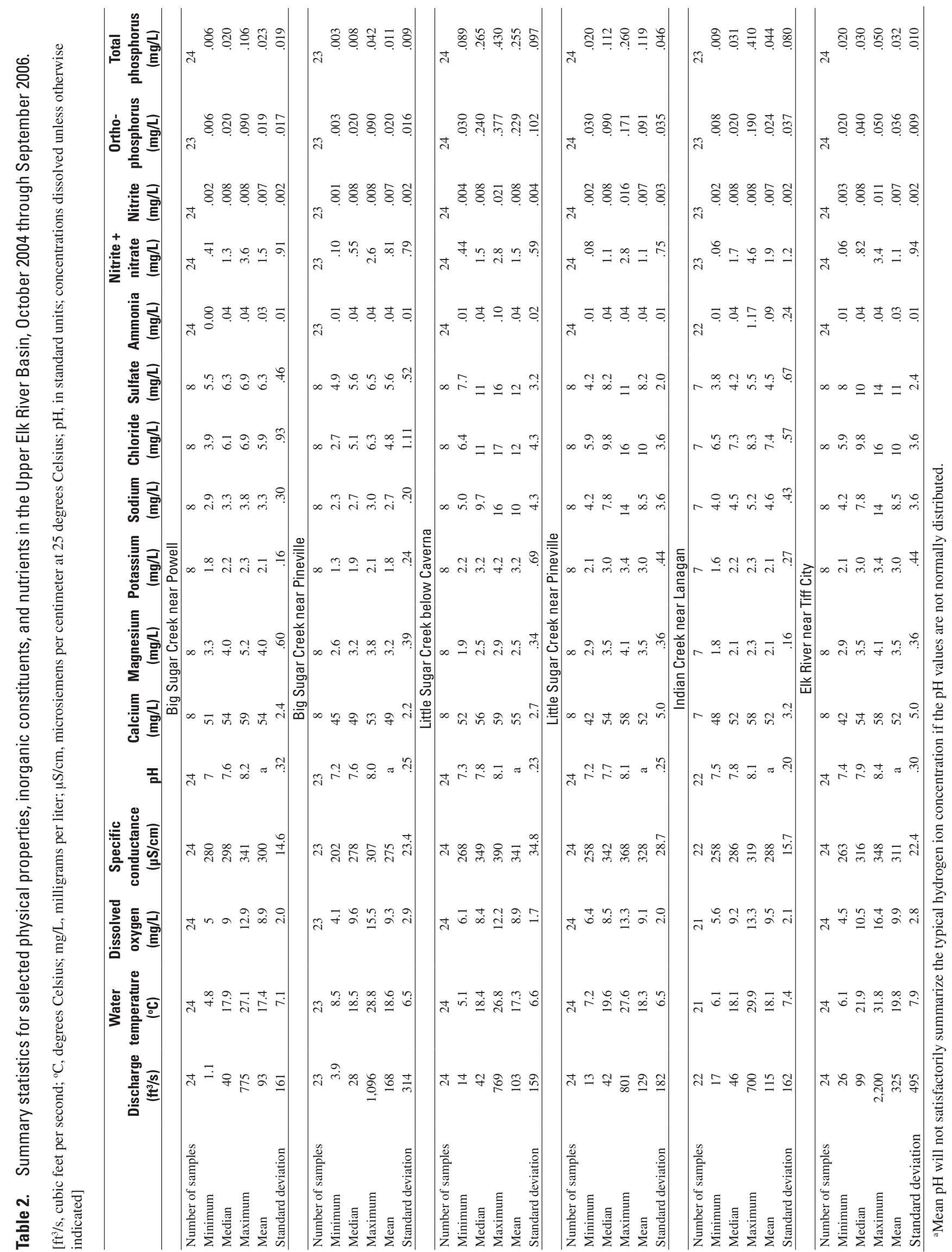




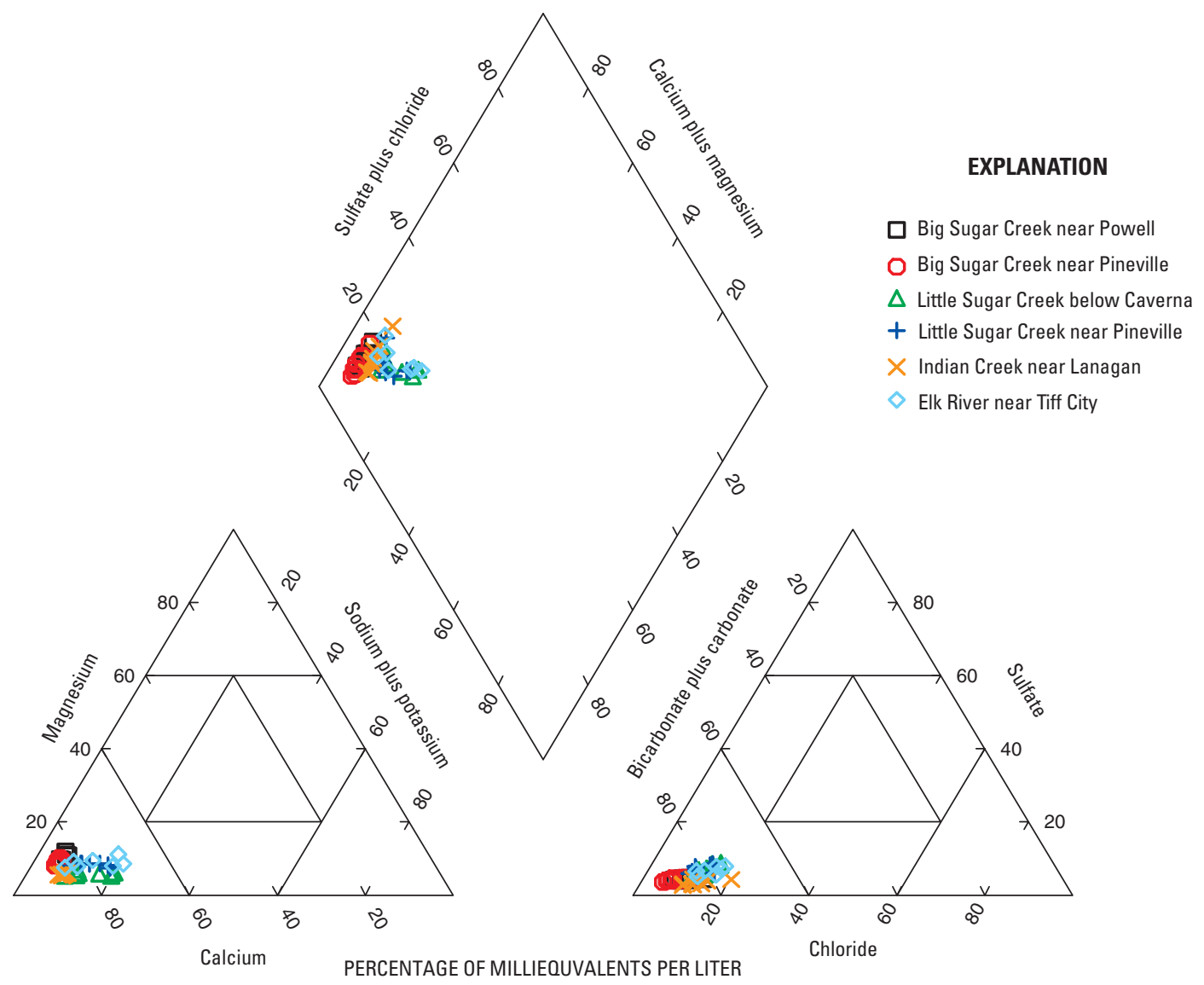

Figure 11. Trilinear diagram of major ions in samples from the Upper Elk River Basin, October 2004 through September 2006.

and agricultural activities seem not to have increased the total phosphorus concentrations at this site.

Nitrate concentrations in the Upper Elk River Basin tended to increase with increasing discharge (fig. 14). Concentrations increased near the beginning of the ambient sample collection in November 2004 and continued to increase through January 2005, when they began to rather substantially decrease through the summer, fall, and winter of 2005 along with a corresponding decrease in discharge. During the summer of 2006, an increased concentration was detected, and a smaller decrease was detected in September 2006.

Total phosphorus concentrations tended to be inversely related to discharge in the ambient samples (fig. 15). Some of the largest concentrations at Little Sugar Creek near Pineville were in samples collected at some of the smallest discharges, indicating point sources of the nutrient. Concentrations in samples from all sites, except for those from Little Sugar Creek, were less than $0.11 \mathrm{mg} / \mathrm{L}$.

\section{Stormwater Water Quality}

Stormwater samples were collected at the four sites with continuous streamflow gaging stations-Big Sugar Creek near Powell, Little Sugar Creek near Pineville, Indian Creek near Lanagan, and the Elk River near Tiff City (fig. 1). Three storms were sampled at each site (table 3). One of the ambient samples at Indian Creek was collected the day after storm samples were collected in May 2005 and is included with the stormwater samples.

The $\mathrm{pH}$ and specific conductance values in stormwater samples generally were less than the values in the ambient samples except for the values in stormwater samples collected at Little Sugar Creek near Pineville. In those samples, $\mathrm{pH}$ values ranged from 7.9 to 8.2 (table 3 ), and specific conductance values ranged from 237 to $351 \mu \mathrm{S} / \mathrm{cm}$. The $\mathrm{pH}$ values in the ambient samples from Little Sugar Creek near Pineville were 8.1 or less, and specific conductance values ranged from 258 to $368 \mu \mathrm{S} / \mathrm{cm}$.

Stormwater samples generally had major ion concentrations that were slightly less than the concentrations in the ambient samples. However, sulfate concentrations in stormwater samples at Little Sugar Creek near Pineville ranged from 8.8 to $20.1 \mathrm{mg} / \mathrm{L}$, and concentrations from ambient samples ranged from 4.2 to $11.4 \mathrm{mg} / \mathrm{L}$.

Major ion concentrations at sampling sites on Little Sugar and Indian Creek and the Elk River generally were inversely related to discharge (table 3). However, potassium concentrations at Indian Creek near Lanagan increased with increasing discharge during the storm of May 2005, which indicates a runoff-derived source for this constituent. Leaching of potas- 

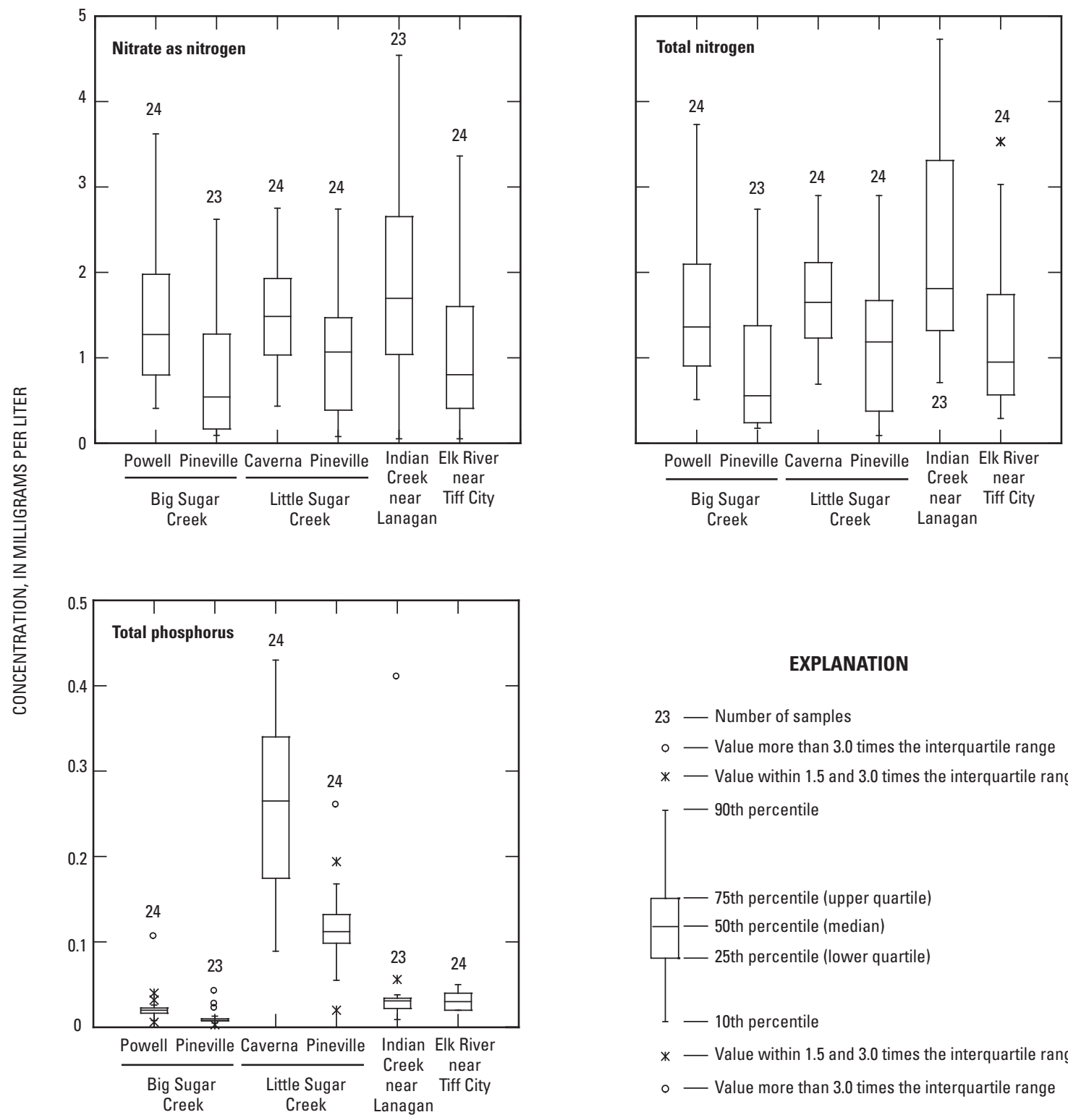

\section{EXPLANATION}

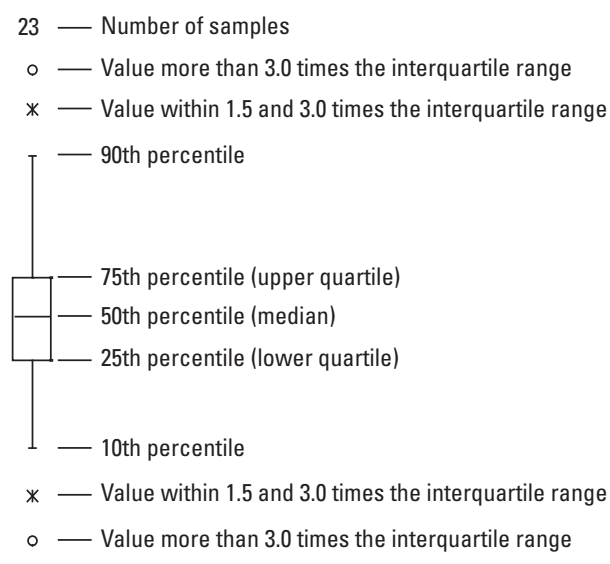

Figure 12. The distribution of nutrient concentrations in samples from the Upper Elk River Basin, October 2004 through September 2006.

sium from soils and organic matter can produce this increase with increasing discharge (Hem, 1985).

In stormwater samples, indicator fecal bacteria densities (fecal coliform and E. coli) generally increased with increasing discharge. Bacteria densities were greater than $200 \mathrm{col} / 100$ $\mathrm{mL}$ in all stormwater samples except for one sample from the Elk River near Tiff City (fecal coliform density of less than $100 \mathrm{col} / 100 \mathrm{~mL}$ ). Bacteria densities for most samples were cultured from samples that had been collected by an automatic sampler, and the samples had been stored for varying times in polyethylene, unsterilized bottles. This is not standard USGS protocol for determining bacteria densities, which requires sample analysis within 6 hours of sample collection (Myers and Wilde, 2003). Some bacterial die-off would be expected based on the longer than normal hold times. Because fecal indicator bacteria densities in stormwater samples tend to be large, the use of cleaned, but not sterile, bottles should not cause a substantial increase in bacterial density. The bacteria densities for the storm of May 2006 at Little Sugar Creek near Pineville and Indian Creek near Lanagan were collected using standard USGS protocol.

Although all sites were not sampled for all storms, nitrate concentrations generally were largest in samples from Big Sugar Creek near Powell-most notably in samples from the storms in November 2004 and April 2006 (fig. 16). Concentrations of nitrate and total phosphorus tended to be slightly larger for the storm of November 2004 as compared to the concentrations detected for the other storms. Discharges at 

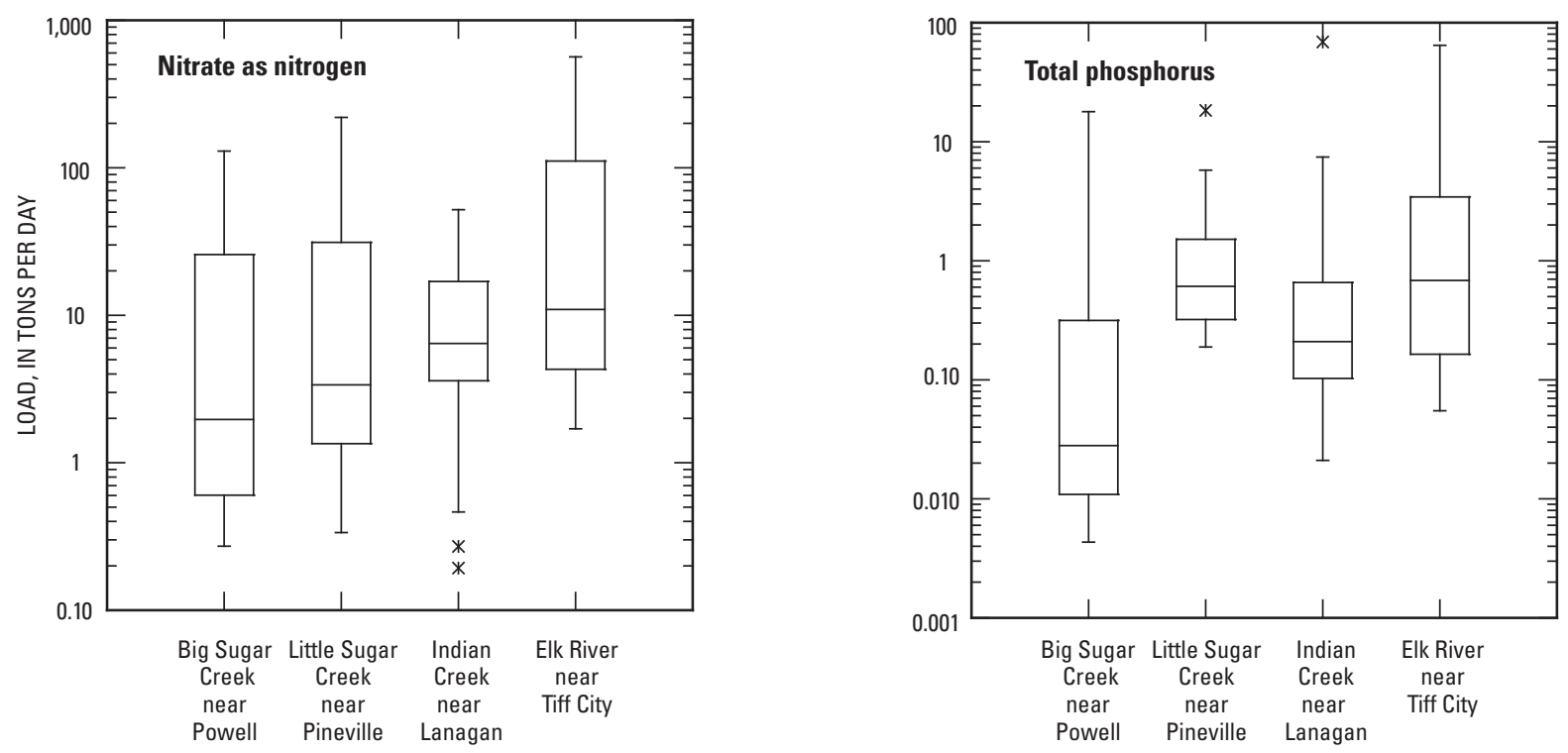

EXPLANATION

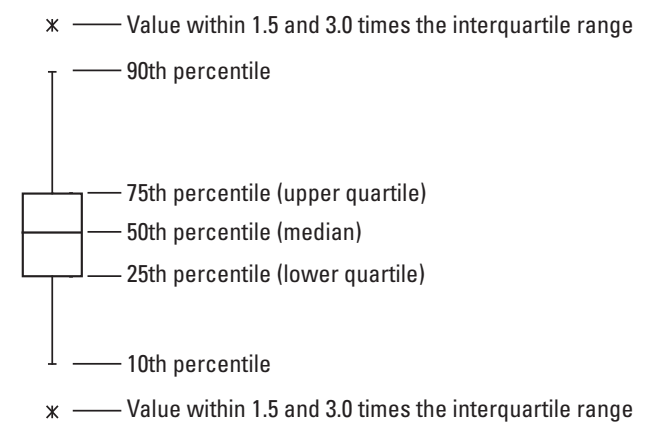

Figure 13. The distribution of monthly nutrient loads in samples from the Upper Elk River Basin, October 2004 through September 2006.

Big Sugar Creek near Powell and the Elk River near Tiff City were largest for that storm. This storm followed a period of decreased flow from September to November 2004 (discharge at the Elk River near Tiff City was less than $100 \mathrm{ft}^{3} / \mathrm{s}$ for much of this period). The nitrate concentrations in stormwater samples ranged from 133 to 179 percent of the concentration in the ambient samples. The total phosphorus concentrations in the stormwater samples ranged from about 200 to more than 600 percent of the concentration in the ambient samples.

Nitrate concentrations in stormwater samples generally increased with increasing discharge and decreased with decreasing discharge at Big Sugar Creek near Powell and the Elk River near Tiff City, which may indicate similar sources and modes of transport during stormwater runoff. Samples collected from two of the three storms at Indian Creek near Lanagan had decreasing nitrate concentrations with increasing discharge. Total phosphorus concentrations at all sites generally increased with increasing discharge.

Nutrient loads for stormwater samples were largest in samples from the Elk River near Tiff City (fig. 17). The loads calculated at this site for the storm of November 2004 were the largest for all storms sampled. Small concentrations of nutrients carried in large storm flows can deliver extremely large loads of nutrients. For example, in the storm of November 2004, the nitrate load at Big Sugar Creek near Powell was 13 percent and the total phosphorus load was 32 percent of the load calculated at that site for the entire set of ambient samples collected from October 2004 through September 2006. Also, the total phosphorus load in the samples from the November 2004 storm at the Elk River near Tiff City were 26 percent of the load of the ambient samples.

Samples were collected for nitrogen isotope analyses during two storms. Stable isotopes, including those of nitrogen, are at or near natural abundance levels and usually are reported as delta, a value in parts per thousand (per mil). The samples were analyzed for the ${ }^{15} \mathrm{~N} /{ }^{14} \mathrm{~N}$ isotope ratio (hereafter referred to as $\delta^{15} \mathrm{~N}$ ). The nitrogen isotope values in this report are in parts per thousand (per mil) relative to nitrogen in air (Mariotti, 1983). Samples ( $\delta^{15} \mathrm{~N}$ analyses in per mil) from Big Sugar (+6.23) and Little Sugar Creeks (+11.21) and the Elk 

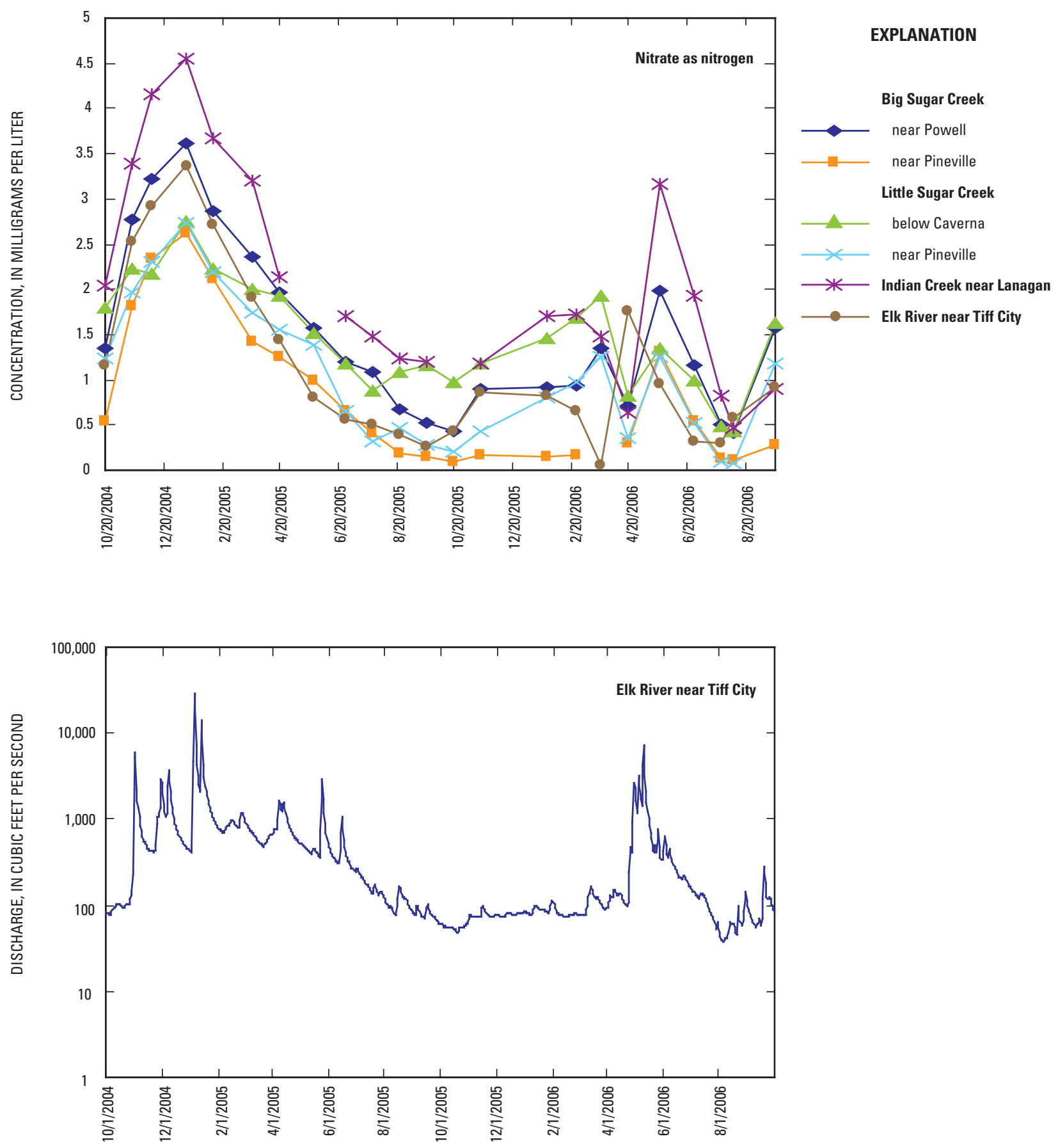

Figure 14. Relation of nitrate as nitrogen concentrations in samples from the Upper Elk River Basin to discharge in the Elk River near Tiff City, October 2004 through September 2006. 

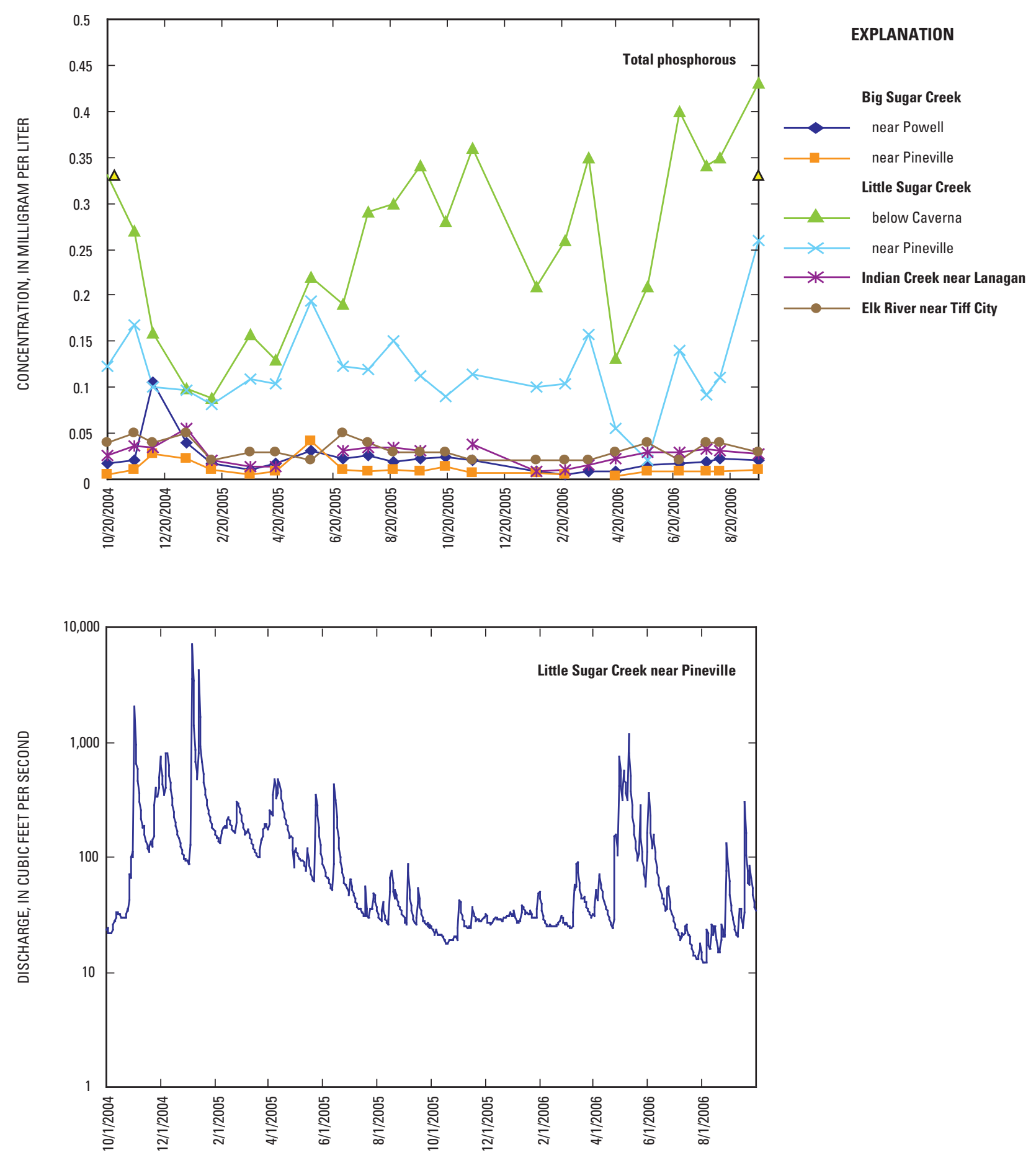

Figure 15. Relation of total phosphorus concentrations in samples from the Upper Elk River Basin to discharge in Little Sugar Creek near Pineville, October 2004 through September 2006. 


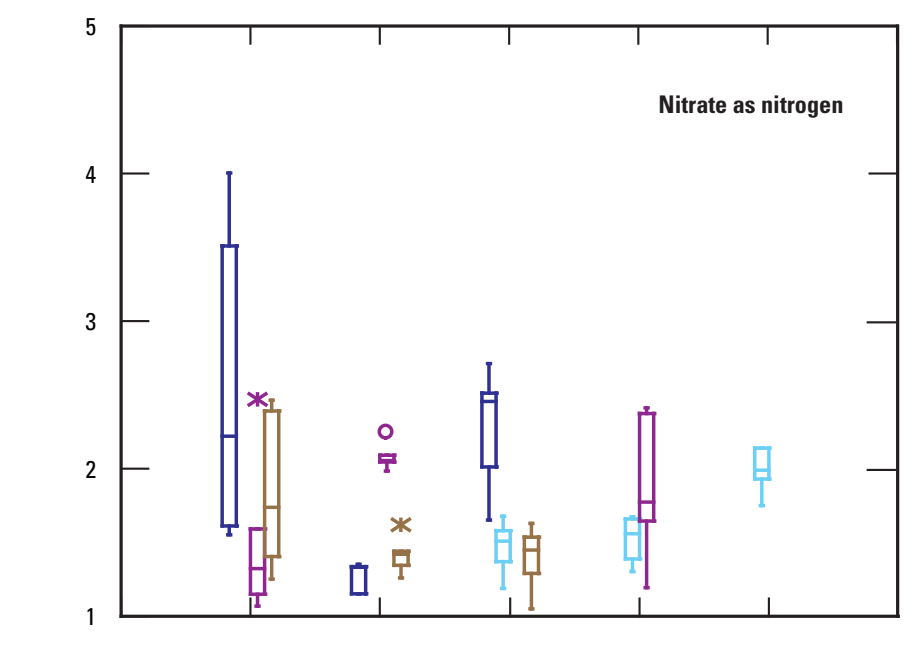

EXPLANATION

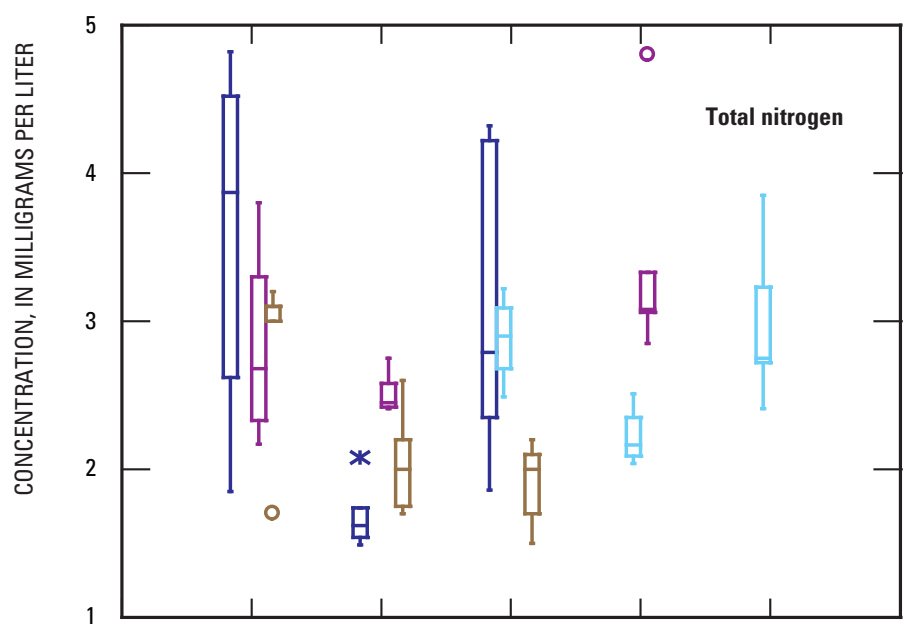

- - Value more than 3.0 times the interquartile range

* - Value within 1.5 and 3.0 times the interquartile range

-90th percentile
— 10 th percentile (upper quartile)
— - 50th percentile (median)
— - Value within 1.5 and 3.0 times the interquartile range

- Value more than 3.0 times the interquartile range

Big Sugar Creek near Powell

Little Sugar Creek near Pineville

$\square \quad$ Indian Creek near Lanagan

$\square \quad$ Elk River near Tiff City

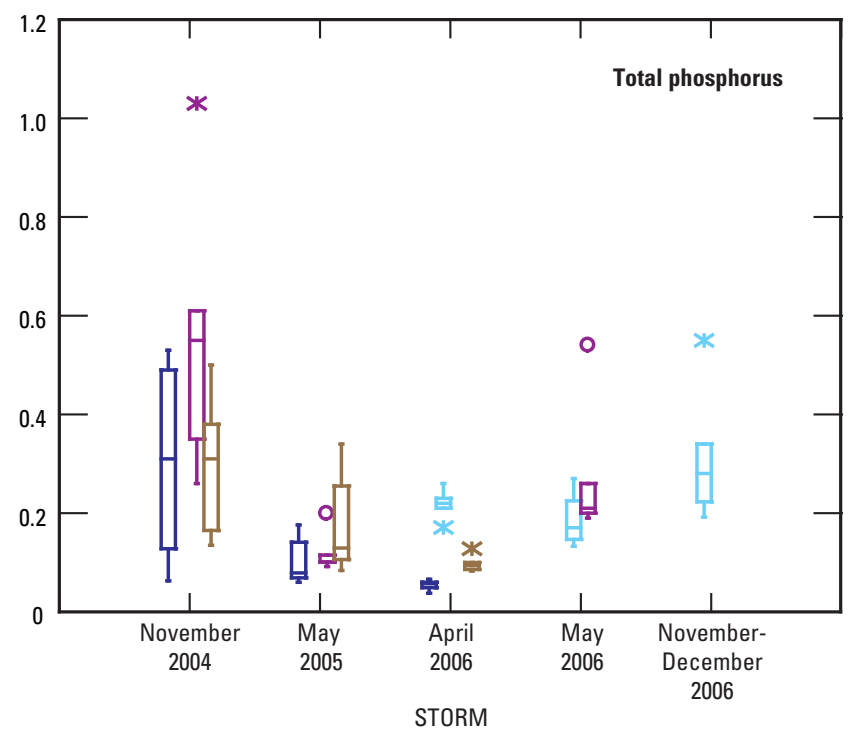

Figure 16. The distribution of nutrient concentrations in stormwater samples in the Upper Elk River Basin, October 2004 through December 2006. 


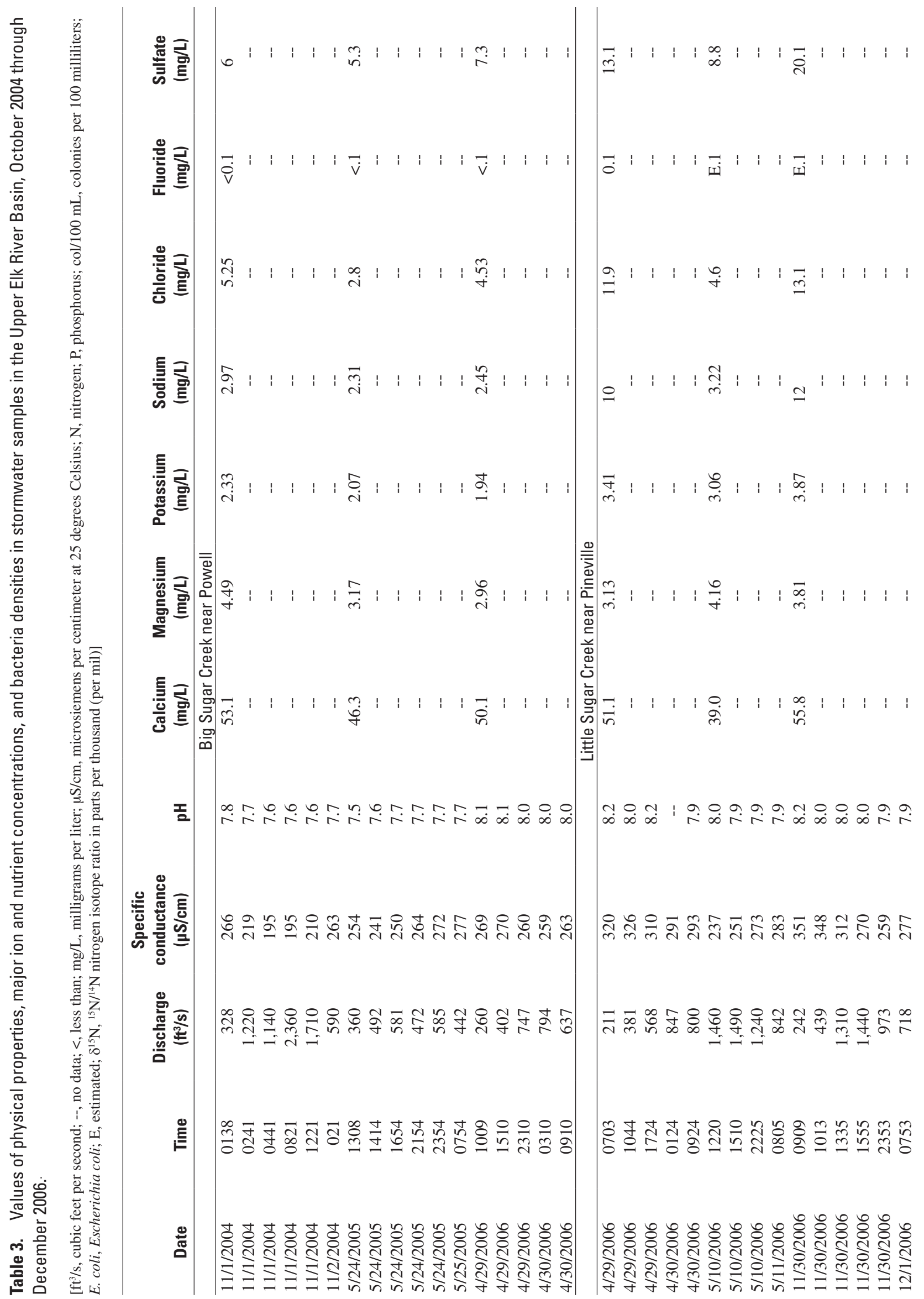




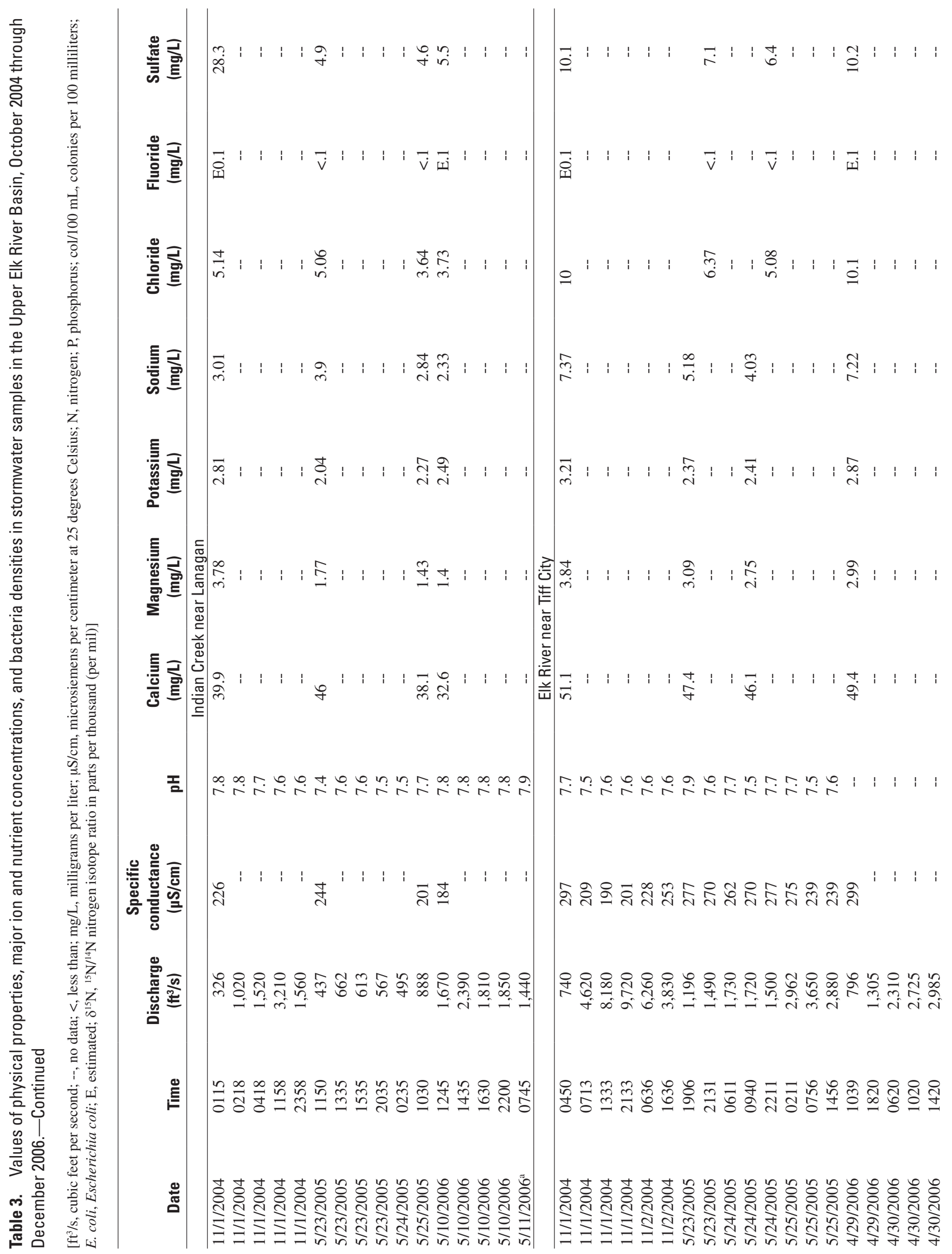




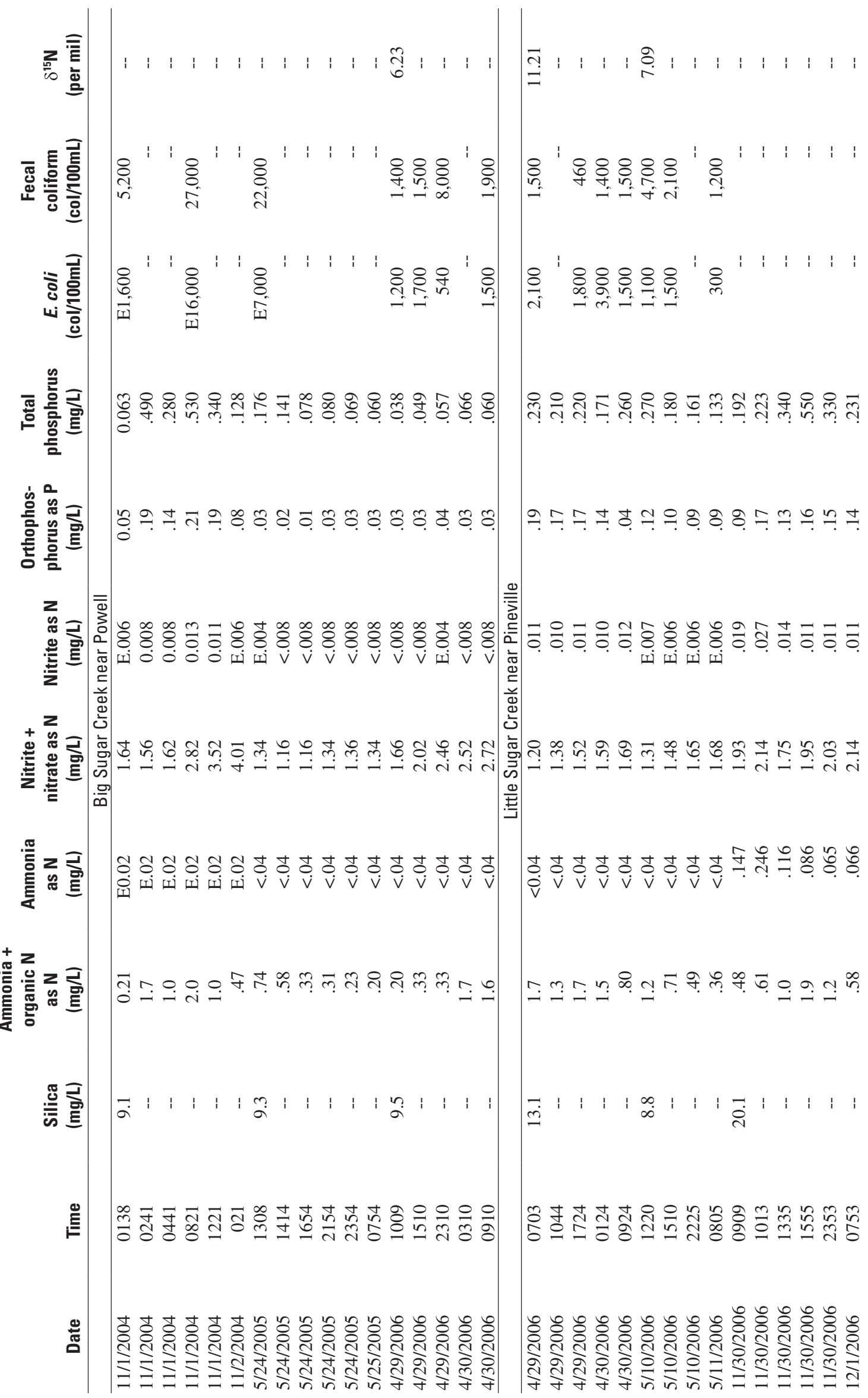




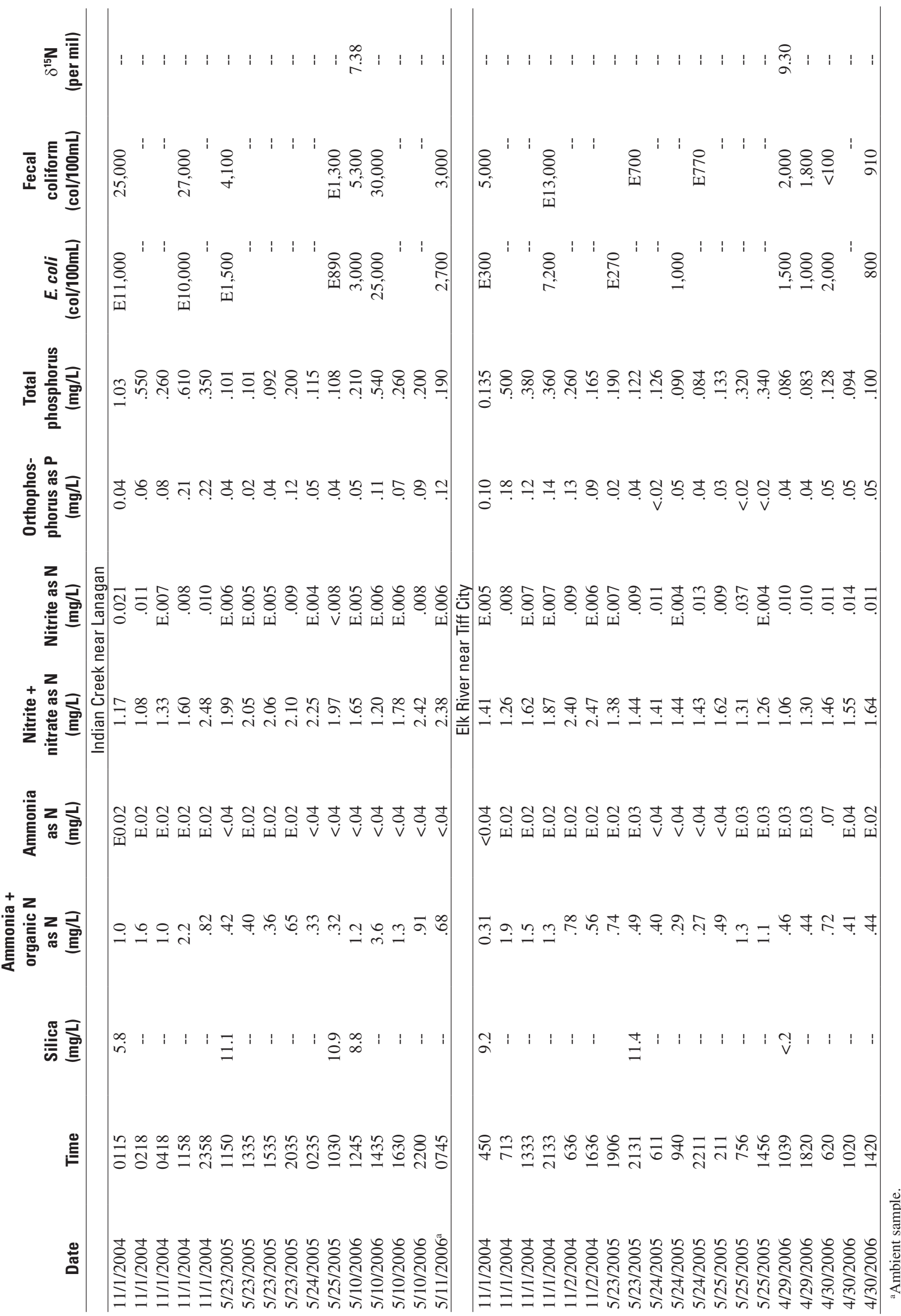




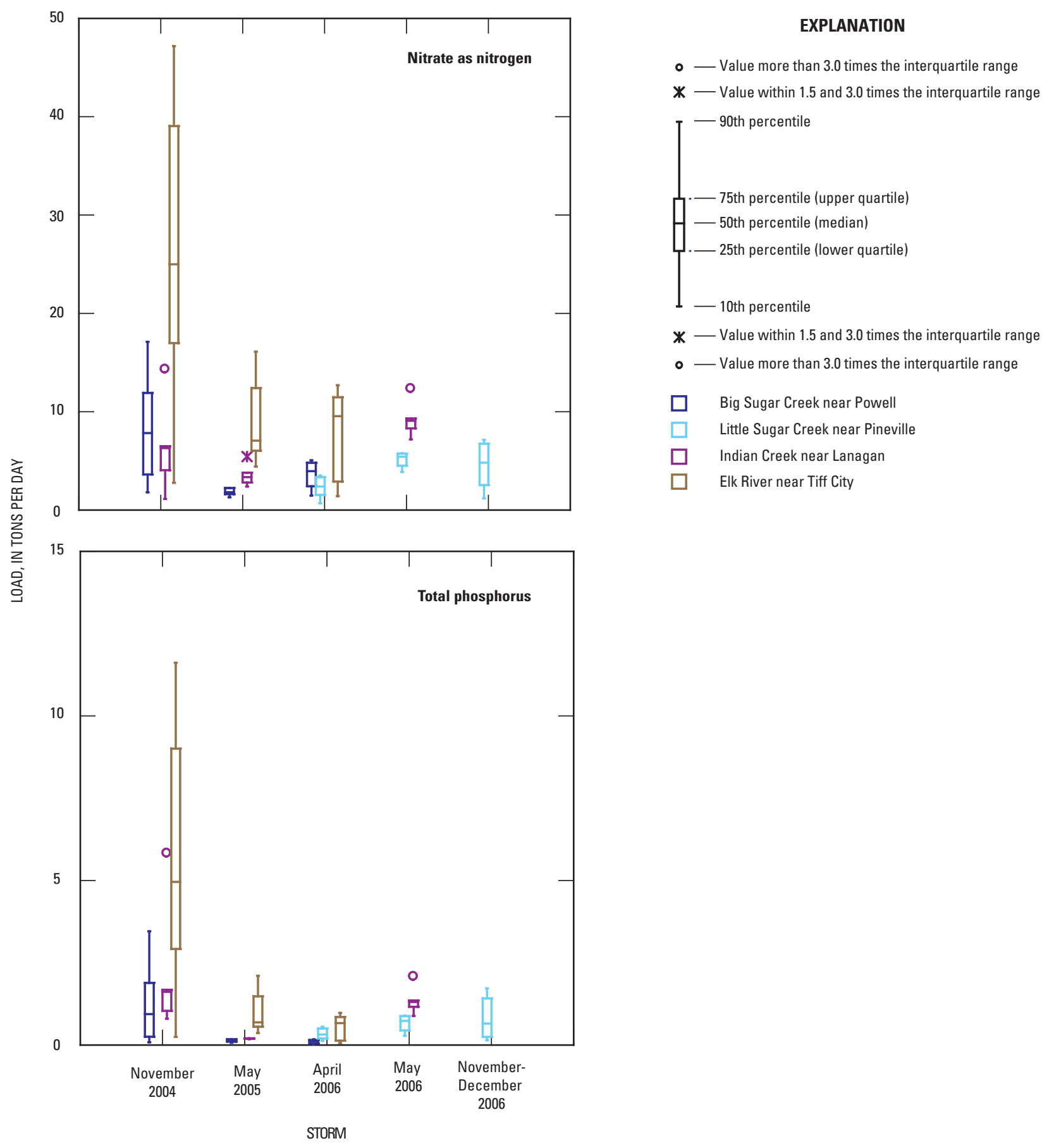

Figure 17. The distribution of nutrient loads in stormwater samples in the Upper Elk River Basin, October 2004 through December 2006. 
River near Tiff City (+9.30) were collected on April 29, 2006, and samples from Little Sugar (+7.09) and Indian Creeks $(+7.38)$ were collected on May 10, 2006. Chemical fertilizer has a value less than +6 per mil, septic tank effluent has a value of -2 to +3 per mil, human sewage has a value of +1 to +11 per mil (Lindsey and Koch, 2004), and animal manure has a value of about +5 to +15 per mil (Jeffrey and others, 1997). The value from Big Sugar Creek near Powell is in the range of animal manure and human sewage. Because no sewage inflow is permitted for this stream, this $\delta^{15} \mathrm{~N}$ value indicates animal sources. The source of the $\delta^{15} \mathrm{~N}$ from Little Sugar Creek with a value of +11.21 per mil is in the range of human sewage and animal manure. Based on effluent inflow into Little Sugar Creek from Bella Vista, Arkansas, and upstream land use, the value probably is indicative of human and animal sources. The $\delta^{15} \mathrm{~N}$ values for May 2006 for Little Sugar and Indian Creeks were about +7.0 per mil, indicating human or animal sources, or a combination.

\section{Seepage Run Water Quality}

The Elk River and its tributaries are the primary discharge areas for precipitation that percolates through the land surface and recharges the ground water in the study area. A seepage run, a series of stream discharge measurements made along a stream reach during a short time to identify where gains and losses in flow occur, was conducted on these streams. A seepage run is designed to be made during periods of minimum streamflow and minimum daily fluctuations (base flow). Base flow is sustained by diffuse ground-water and spring inflow, not by surface runoff. The flow-rate changes were used to identify gaining and losing stream reaches throughout the basin. Water-quality samples also were collected at selected sites to identify where increases or decreases in constituent concentrations occurred.

The USGS conducted a low-flow seepage run on the Elk River and its tributaries from July 31 to August 3, 2006. Discharge was measured at more than 70 sites and water-quality samples were collected at more than 45 sites (fig. 18). The discharge at the Elk River near Tiff City on August 3, 2006, was $40 \mathrm{ft}^{3} / \mathrm{s}$; the discharge during the time of the seepage run was the smallest measured from October 2004 through September 2006. The annual mean discharge from October 2005 through September 2006 was $234 \mathrm{ft}^{3} / \mathrm{s}$ at the Elk River near Tiff City. The Upper Elk River Basin was abnormally dry or under a moderate drought (National Drought Mitigation Center, 2007) at the time of this seepage run. Another seepage run was conducted November 13 and 14, 2006, at eight of the sites from the previous seepage run and an additional site. The second seepage run was conducted at a different time and under different hydrologic conditions. In November, the discharge at the Elk River near Tiff City was $65 \mathrm{ft}^{3} / \mathrm{s}$.

In the first seepage run, discharge measurements indicated that in the Upper Elk River Basin, most of the streams gained flow (table 4; fig. 18). In the upper reach of Big Sugar
Creek, discharge was measured at $1.5 \mathrm{ft}^{3} / \mathrm{s}$ (site BK02) and had increased to about $5 \mathrm{ft}^{3} / \mathrm{s}$ at the gaging station near Powell (site JS06) and remained stable to Big Sugar Creek at Cyclone (site BK11), even with an input of more that $2 \mathrm{ft}^{3} / \mathrm{s}$ from Mikes Creek (site JS09). A decrease of about $2 \mathrm{ft}^{3} / \mathrm{s}$ was measured from Cyclone to below Hambrich Hollow (site BK12). However, the measurement at Hambrich Hollow was rated poor. Discharge at the mouth of Big Sugar Creek (site BK 15) had decreased to $3.6 \mathrm{ft}^{3} / \mathrm{s}$ from $4.8 \mathrm{ft}^{3} / \mathrm{s}$ at the site above Dog Hollow (site BK13), with an additional $0.21 \mathrm{ft}^{3} / \mathrm{s}$ from Dog Hollow (site BK14). The streambed was comprised of gravel for many of the stream reaches in the Big Sugar Creek Basin.

Discharge in Little Sugar Creek was first measured downstream from the lake at Bella Vista, Arkansas (site JR02; 14 $\mathrm{ft}^{3} / \mathrm{s}$ ). It decreased slightly at Little Sugar Creek above Tanyard Creek (site JR74) then increased to $15 \mathrm{ft}^{3} / \mathrm{s}$ at Little Sugar Creek at Missouri Road (site JR01). The discharge at this site was the largest measured in Little Sugar Creek. Discharge at the mouth of Little Sugar Creek (site JR04) was $13 \mathrm{ft}^{3} / \mathrm{s}$, even after small inputs of less than $1 \mathrm{ft}^{3} / \mathrm{s}$ from tributaries to Little Sugar Creek.

Two tributaries, South Indian Creek (site JS17) and North Indian Creek (site JS19), provided about $7 \mathrm{ft}^{3} / \mathrm{s}$ each to the flow of Indian Creek. At Indian Creek near Erie (site JS23) the discharge was $19 \mathrm{ft}^{3} / \mathrm{s}$. The discharge increased slightly at the mouth of Indian Creek from small inflow from springs and tributaries upstream from the mouth.

The discharge measured in the Elk River downstream from the inflow of Big and Little Sugar Creeks (site JR30) was $16 \mathrm{ft}^{3} / \mathrm{s}$. The discharge from Big Sugar Creek (site BK15; 3.6 $\mathrm{ft}^{3} / \mathrm{s}$ ) and Little Sugar Creek (site JR04; $13 \mathrm{ft}^{3} / \mathrm{s}$ ) accounts for this. Discharge in the Elk River upstream from Indian Creek (site BK18) was $15 \mathrm{ft}^{3} / \mathrm{s}$. The inflow from Indian Creek (site JR27) was $21 \mathrm{ft}^{3} / \mathrm{s}$, resulting in a discharge of $36 \mathrm{ft}^{3} / \mathrm{s}$ in the Elk River downstream from Indian Creek. The discharge measured downstream from Noel (site BK24) was $40 \mathrm{ft}^{3} / \mathrm{s}$, which included additional inflows of almost $1.5 \mathrm{ft}^{3} / \mathrm{s}$. Upstream from Tiff City (site BK27), the measured discharge was $38 \mathrm{ft}^{3} / \mathrm{s}$, which was a decrease of almost 5 percent from the discharge in the Elk River downstream from Noel. The discharge at Tiff City was $40 \mathrm{ft}^{3} / \mathrm{s}$.

A few decreases in streamflow were noted, usually from one site to another. The decreases were in Big and Little Sugar Creeks and in the mainstem of the Elk River. In most cases, the decrease was within measurement error (generally less than 8 percent). Because the decreases were small, definitive losing stream reaches could not be identified.

Base-flow conditions, as reflected by the seepage run, indicate that about 52 percent of the discharge at the Elk River near Tiff City is contributed by Indian Creek. Little Sugar Creek contributes about 32 percent and Big Sugar Creek contributes about 9 percent of the discharge in the Elk River near Tiff City. Only about 7 percent of the discharge at Tiff City comes from the mainstem of the Elk River.

Specific conductance values during the seepage run were $453 \mu \mathrm{S} / \mathrm{cm}$ or less; the specific conductance generally was 


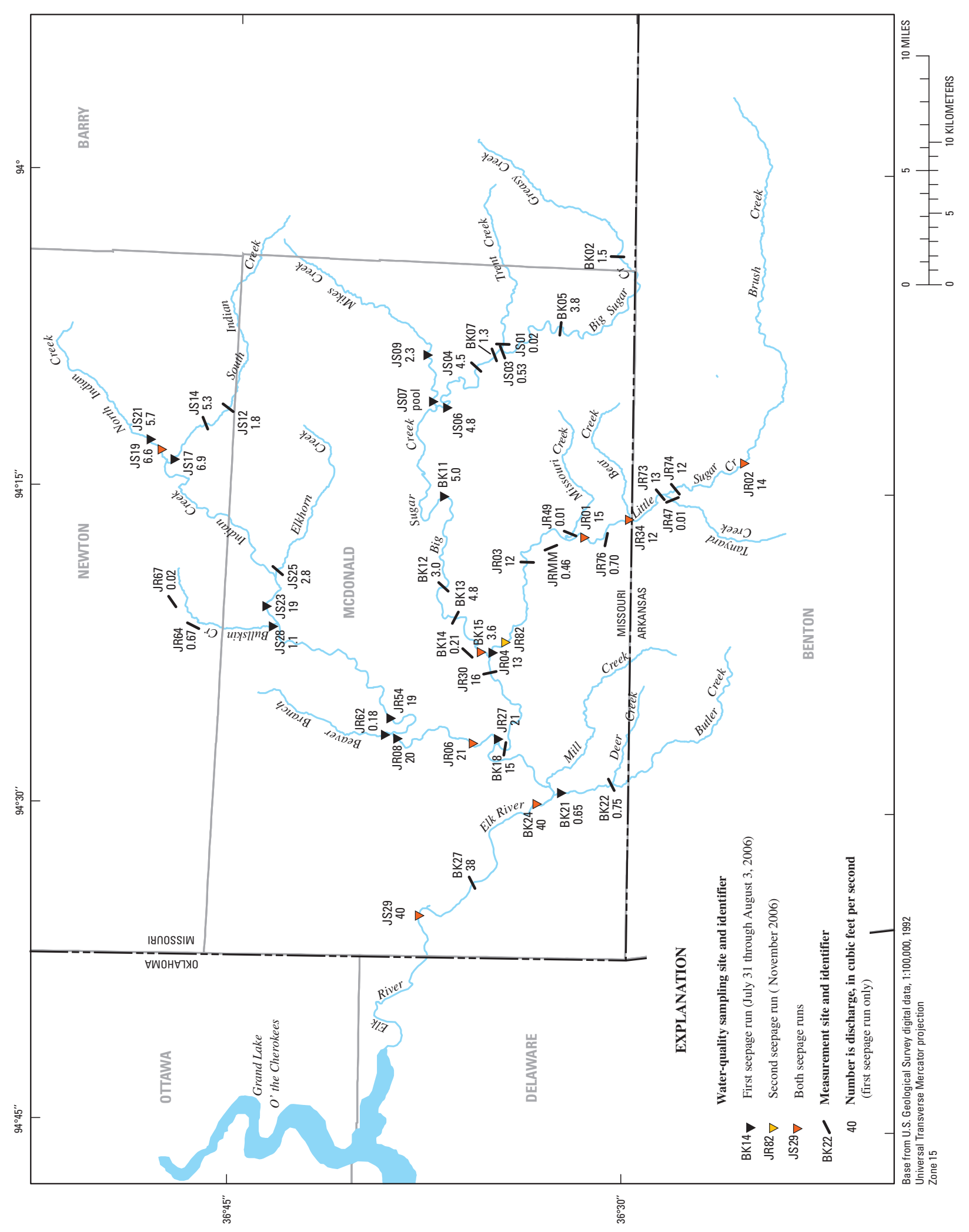

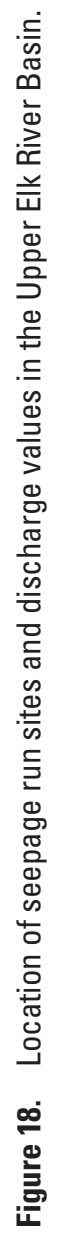


less than $350 \mu \mathrm{S} / \mathrm{cm}$ in Big Sugar Creek and the Elk River and tributaries. Specific conductance values generally were larger than $350 \mu \mathrm{S} / \mathrm{cm}$ in Little Sugar Creek.

Potassium, sodium, chloride, and sulfate concentrations in samples from Little Sugar Creek and tributaries were larger relative to most of the other samples (table 4). The concentrations in these samples possibly could indicate greater wastewater effects in this basin. Effluent from municipal wastewater treatment plants commonly contains increased concentrations of potassium, sodium, chloride, and sulfate, relative to calcium and magnesium (Schumacher, 2001).

Fecal indicator bacteria densities generally did not exceed the Missouri water-quality criteria for whole-body-contact recreation from samples collected during the seepage run in July and August. E. coli densities larger than $126 \mathrm{col} / 100 \mathrm{~mL}$ were counted in samples from two tributaries to Little Sugar Creek (sites JR49 and JRMM) and a tributary to Indian Creek (site JS14). Evidence of cattle was present at the site on Missouri Creek (E. coli of $230 \mathrm{col} / 100 \mathrm{~mL}$ ). Fecal coliform densities exceeded $200 \mathrm{col} / 100 \mathrm{~mL}$ at four sites-three tributaries to Little Sugar Creek (sites JR47, JR49, and JRMM; two had large E. coli densities) and a tributary to Indian Creek (site JS17) that did not have the large E. coli density.

The nitrate concentrations in most samples from the first seepage run were about $1 \mathrm{mg} / \mathrm{L}$ or less (table 4; fig. 19), especially in Big and Little Sugar Creek and their tributaries and in the mainstem of the Elk River. The exceptions were in samples from Indian Creek and its tributaries, especially in the upper reaches of the basin. Concentrations in two of the three springs sampled in the Indian Creek Basin were the largest detected$4.34 \mathrm{mg} / \mathrm{L}$ from Sears Spring (site JS21) and $11.1 \mathrm{mg} / \mathrm{L}$ from the spring at MoArk site 13 (site JR67). Concentrations in the upper reaches of the Indian Creek Basin were larger than 2.50 $\mathrm{mg} / \mathrm{L}$ and decreased downstream from $1.66 \mathrm{mg} / \mathrm{L}$ in samples from Indian Creek near Erie (site JS23) to less than $1.0 \mathrm{mg} / \mathrm{L}$ at the mouth of Indian Creek (JR27). Many livestock production facilities in the Upper Elk River Basin are in the upper reaches of the Indian Creek Basin (fig. 4).

Total phosphorus concentrations in the seepage run samples in the summer of 2006 were less than $0.1 \mathrm{mg} / \mathrm{L}$ (table 4; fig. 20) with a few exceptions: $0.128 \mathrm{mg} / \mathrm{L}$ from the spring at MoArk site 13 (site JR67) and samples from Little Sugar Creek and its tributaries. Total phosphorus concentrations were largest in the upper reaches of the Little Sugar Creek Basin downstream from Bella Vista (site JR02; $0.67 \mathrm{mg} / \mathrm{L}$ ), with a trend of generally decreasing concentrations to the mouth of Little Sugar Creek (site JR04; $0.097 \mathrm{mg} / \mathrm{L}$ ). Tributary inflow did not contribute to the large total phosphorus concentrations detected in the basin, but diluted the concentrations.

Nitrate concentrations from the mouth of the three major tributaries to the Elk River in the study area included 0.223 $\mathrm{mg} / \mathrm{L}$ (Big Sugar Creek), $0.102 \mathrm{mg} / \mathrm{L}$ (Little Sugar Creek), $0.648 \mathrm{mg} / \mathrm{L}$ (Indian Creek). The nitrate concentration detected in the sample from the Elk River near Tiff City was 0.295 $\mathrm{mg} / \mathrm{L}$. The total phosphorus concentration detected in the sample from the Elk River near Tiff City $(0.039 \mathrm{mg} / \mathrm{L}$ decreased by about 60 percent from the concentration detected in the sample from Little Sugar Creek near the mouth $(0.097 \mathrm{mg} / \mathrm{L})$.

Selected wastewater indicator (table 5) and pharmaceutical compounds were analyzed in samples from six sites during the first seepage run. Six wastewater indicator compounds were detected-most of the concentrations were estimated or presence verified, but not quantified (table 6). The remaining wastewater indicator compounds were detected at less than 1 microgram per liter $(\mu \mathrm{g} / \mathrm{L})$. Four of the six compounds were detected in the sample from Little Sugar Creek at Caverna (site JR34); one compound was detected in the sample from Big Sugar Creek at the mouth (site BK15) and the Elk River near Tiff City (site JS29). Three pharmaceutical compounds were detected in the first seepage run samples; all detections were estimated and were in the sample from Little Sugar Creek at Caverna. Compounds included carbamazepine (0.040 $\mu \mathrm{g} / \mathrm{L}$, high blood pressure), diltiazem $(0.003 \mu \mathrm{g} / \mathrm{L}$, urinary tract infections), and sulfamethoxazole $(0.038 \mu \mathrm{g} / \mathrm{L}$, manic depression and bipolar disorder).

Optical brighteners are added to laundry detergents as whiteners for cotton and other plant-derived textiles. Detection of optical brighteners in a water sample is an indicator of effects from septic systems. Samples were collected at all sites shown in table 4 , and no optical brighteners were detected in any of the samples.

Chlorophyll $a$ is the predominant type of pigment in algae and blue-green algae. Excessive quantities are indicative of algal blooms. Chlorophyll $a$ concentrations generally were less than $10 \mu \mathrm{g} / \mathrm{L}$ in samples (table 4), except for Little Sugar Creek below Bella Vista, Ark. (site JR02; $39.2 \mu \mathrm{g} / \mathrm{L}$ ) and Maness Spring (site JR64; $38.8 \mu \mathrm{g} / \mathrm{L}$ ). Excessive nutrient concentrations can stimulate algal growth. Little Sugar Creek below Bella Vista had the largest total phosphorus concentration detected in the seepage run samples $(0.670 \mathrm{mg} / \mathrm{L})$.

Samples were collected for nitrogen isotope analyses throughout the upper Elk River Basin in conjunction with the seepage run. Samples were collected at the mouth of Big Sugar (site BK15), Little Sugar (site JR04), and Indian Creeks (site JR27) and the Elk River near Tiff City (site JS29). A sample also was collected at Little Sugar Creek at Caverna (site JS34). The $\delta^{15} \mathrm{~N}$ values at all sites were greater than +11 per mil except for the sample from the mouth of Big Sugar Creek ( +8.5 per mil). Values greater than +12 per mil indicate the source likely originates from organic nitrogen (human sewage or animal manure). Manure has a $\delta^{15} \mathrm{~N}$ value of about +5 to +15 per mil (Jeffrey and others, 1997), and $\delta^{15} \mathrm{~N}$ value of human sewage is +1 to +11 per mil (Lindsey and Koch, 2004). Chemical fertilizers have a $\delta^{15} \mathrm{~N}$ value of less than +6 per mil (Lindsay and Koch, 2004). Water from Little Sugar Creek from both sites and the Elk River near Tiff City probably has a component of effluent mixed with animal manure and fertilizer from lawns and golf courses. Indian Creek is a receiving stream for effluent from local communities: however, septic tank effluent generally has a $\delta^{15} \mathrm{~N}$ value of less than +4 per mil, which indicates the source of the $\delta^{15} \mathrm{~N}$ value in Indian Creek likely is animal manure and human sewage. 


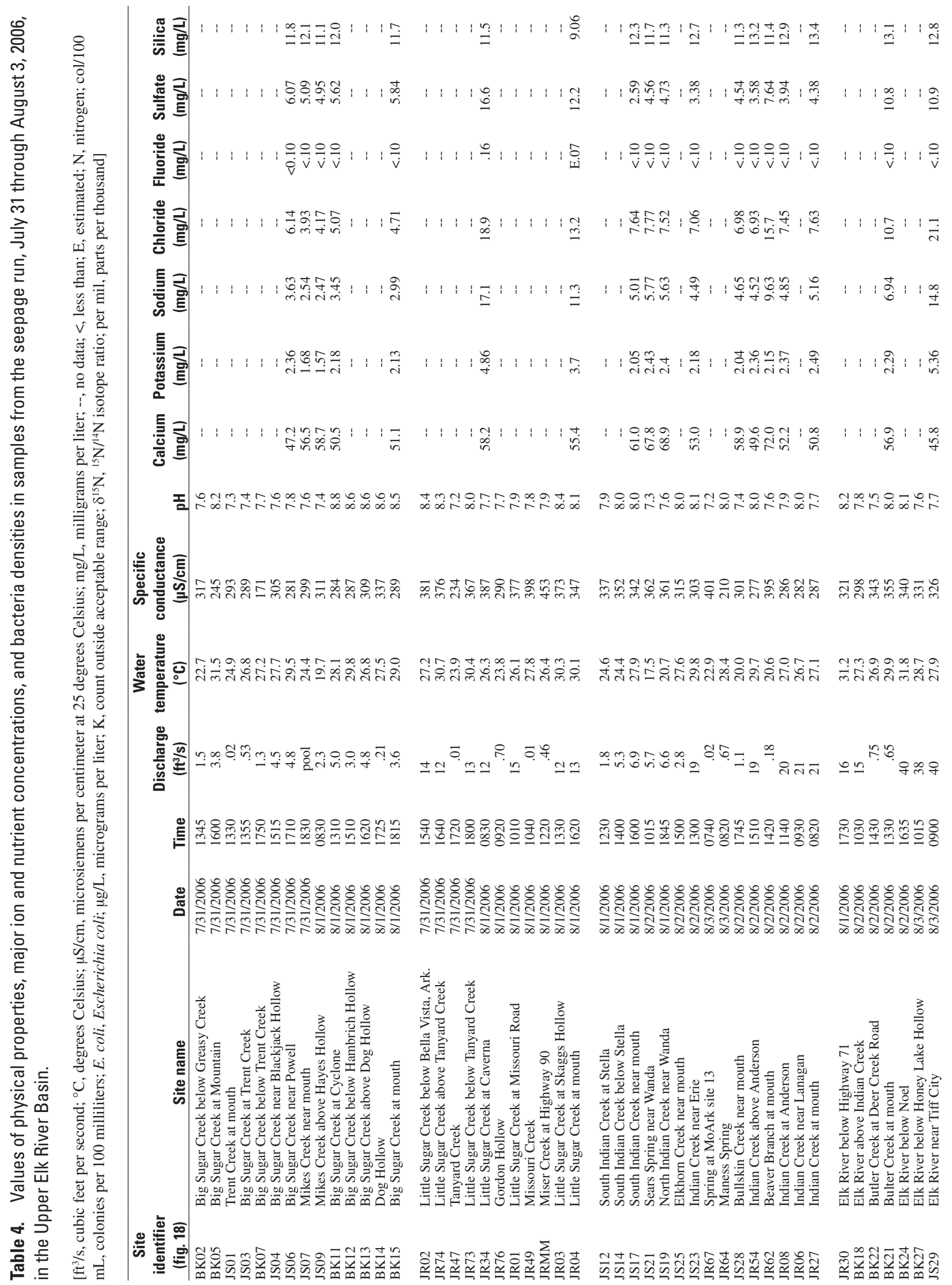




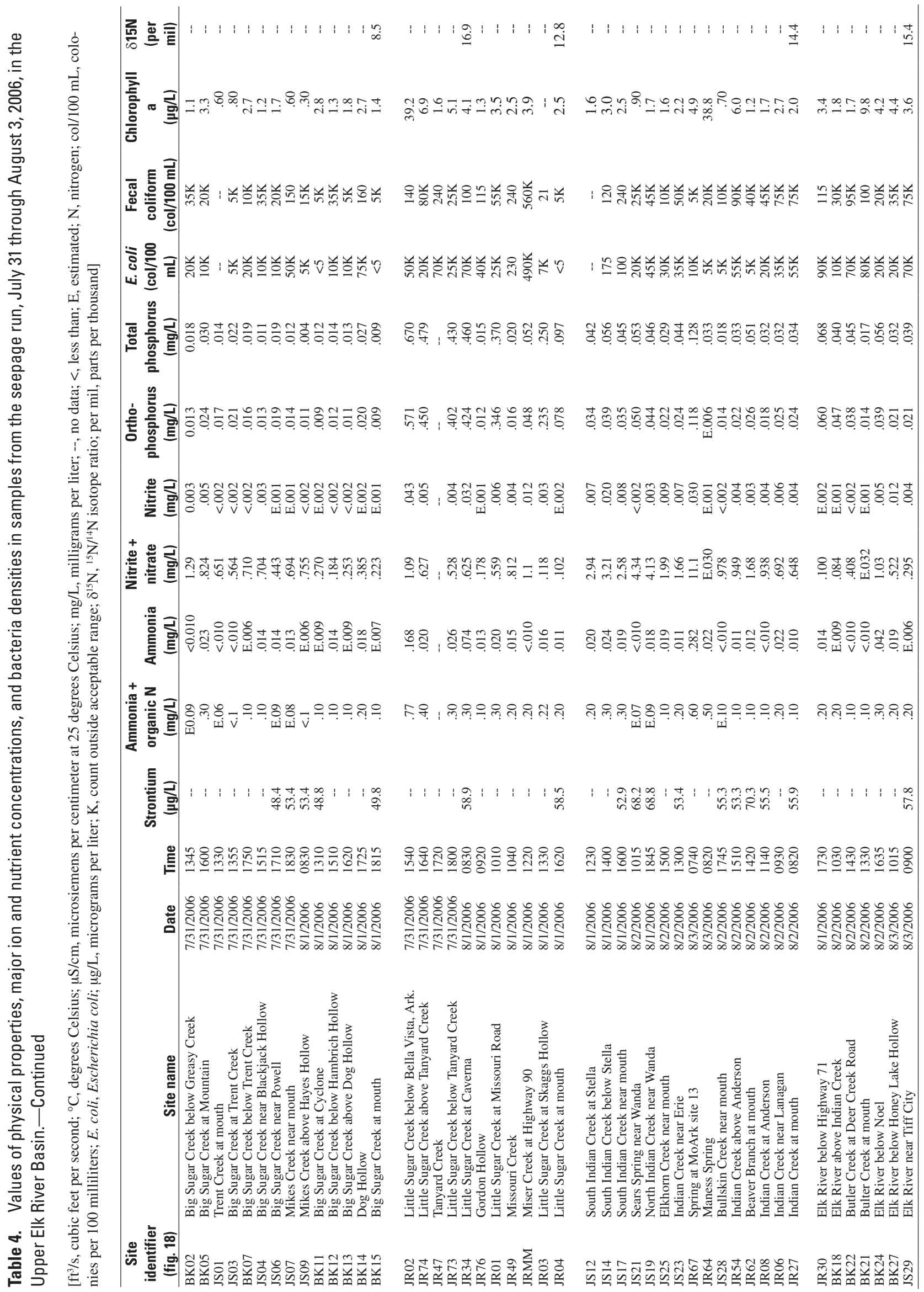




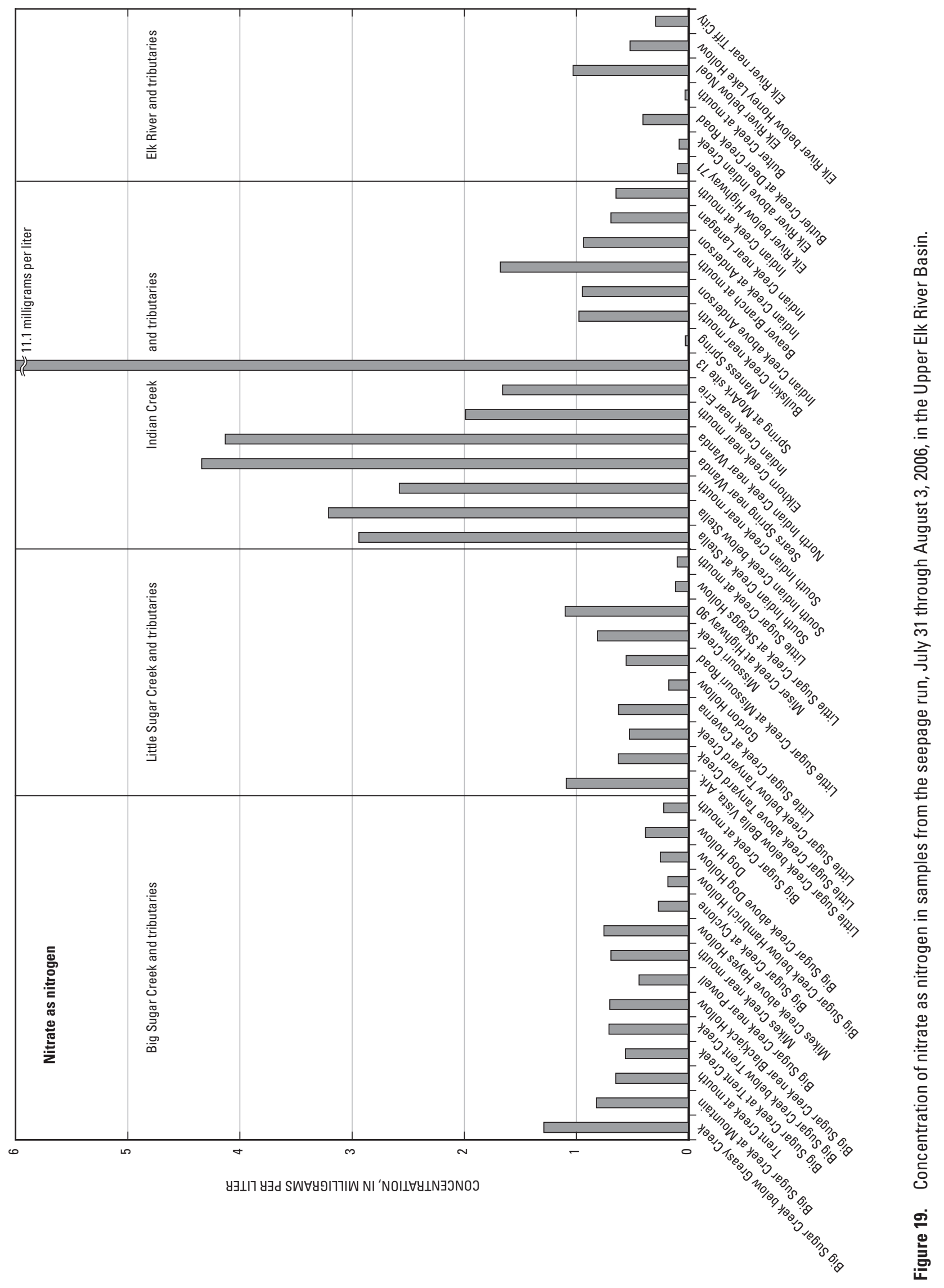




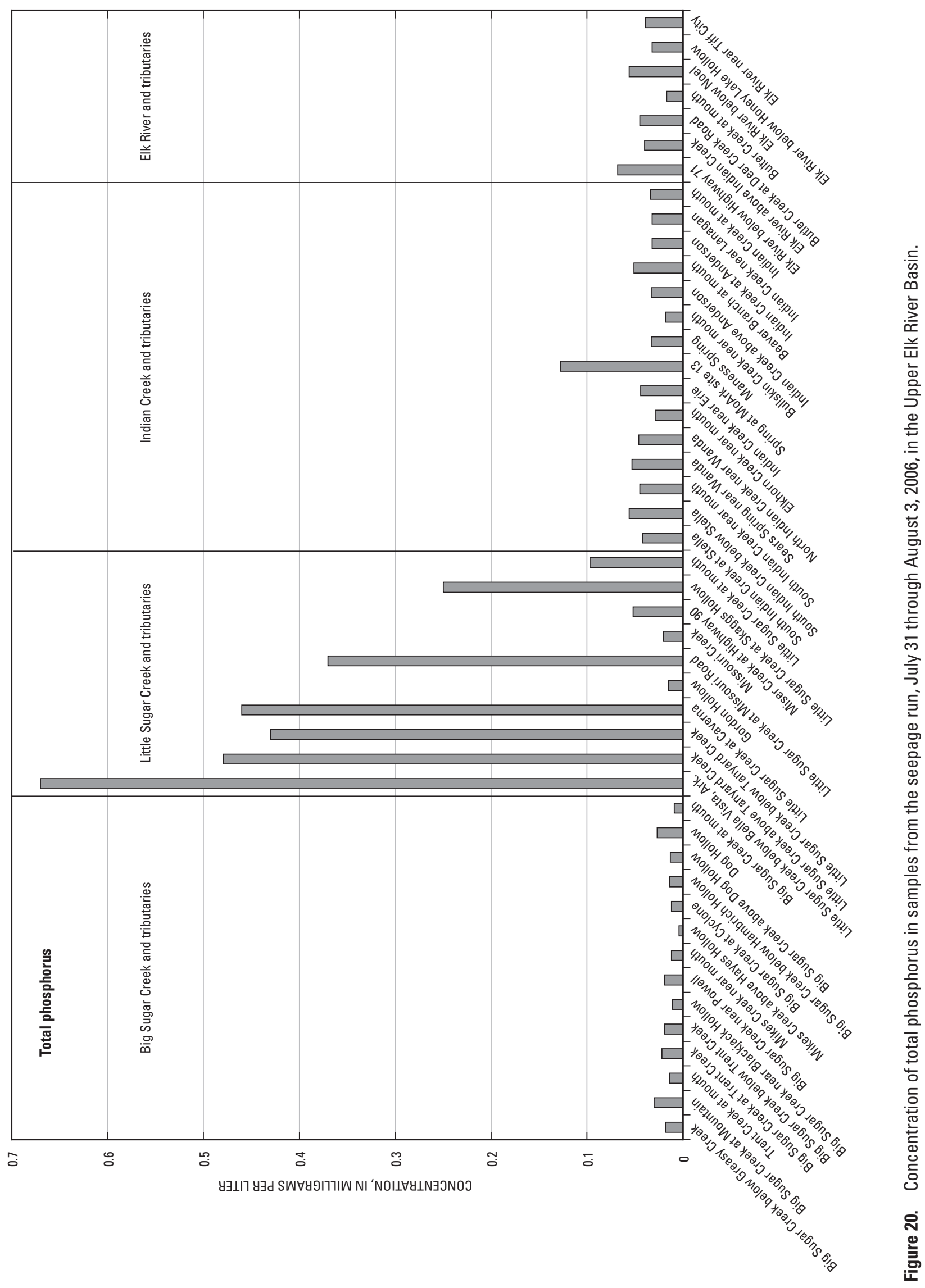


Table 5. Wastewater indicator compounds analyzed and reporting limit for samples collected during the seepage run, July 31-August 3, 2006, in the Upper Elk River Basin.

[ $\mu \mathrm{g} / \mathrm{L}$, micrograms per liter; AHTN, acetyl hexamethyl tetrahydronaphthalene; DEET, N,N-diethyl-meta-toluamide; HHCB, hexahydrohexamethylcyclopentabenzopyran; bold-faced compounds were detected]

\begin{tabular}{|c|c|c|c|}
\hline Compound & $\begin{array}{c}\text { Reporting limit } \\
(\mu \mathrm{g} / \mathrm{L})\end{array}$ & Compound & $\begin{array}{c}\text { Reporting limit } \\
(\mu \mathrm{g} / \mathrm{L})\end{array}$ \\
\hline 1-Methylnaphthalene & 0.2 & Cholesterol & 0.8 \\
\hline 1,4-Dichlorobenzene & .2 & Cotinine & .8 \\
\hline 2-Methylnaphthalene & .2 & d-Limonene & .2 \\
\hline 2,6-Dimethylnaphthalene & .2 & DEET & .2 \\
\hline 2,2',4,4'-Tetrabromodiphenyl ether & .2 & Diazinon & .2 \\
\hline 3-beta-Coprostanol & .8 & Dichlorvos & .4 \\
\hline 3-Methyl-1(H)-indole (Skatole) & .2 & Diethyl phthalate & .2 \\
\hline 3-t-butyl-4-hydroxy anisole (BHA) & .2 & Fluoranthene & .2 \\
\hline 3,4-Dichlorophenyl isocyanate & 2 & НHCB & .2 \\
\hline 4-Cumylphenol & .2 & Indole & .2 \\
\hline 4-n-Octylphenol & .2 & Isoborneol & .2 \\
\hline 4-Nonylphenol diethoxylates & 3.2 & Isophorone & .2 \\
\hline 4-Octylphenol diethoxylates & .32 & Isopropylbenzene & .2 \\
\hline 4-Octylphenol monoethoxylates & 1 & Isoquinoline & .2 \\
\hline 4-tert-Octylphenol & .2 & Menthol & .2 \\
\hline 5-Methyl-1H-benzotriazole & 1.6 & Metalaxyl & .2 \\
\hline 9,10-Anthraquinone & .2 & Methyl salicylate & .2 \\
\hline Anthraquinone & .2 & Metolachlor & .2 \\
\hline Acetophenone & .2 & Naphthalene & .2 \\
\hline AHTN & .2 & Nonylphenol, monoethoxy- (total) & 2 \\
\hline Anthracene & .2 & p-Cresol & .2 \\
\hline Atrazine & .2 & para-Nonylphenol (total) & 1.6 \\
\hline Benzo[a]pyrene & .2 & Phenanthrene & .2 \\
\hline Benzophenone & .2 & Phenol & .2 \\
\hline beta-Sitosterol & .8 & Pentachlorophenol & .8 \\
\hline beta-Stigmastanol & .8 & Prometon & .20 \\
\hline Bisphenol A & .4 & Pyrene & .20 \\
\hline bis(2-Ethylhexyl) phthalate & 2 & Tetrachloroethylene & .40 \\
\hline Bromacil & .2 & Tributyl phosphate & .2 \\
\hline Bromoform & .2 & Triclosan & .20 \\
\hline Caffeine & .2 & Triethyl citrate (ethyl citrate) & .20 \\
\hline Camphor & .2 & Triphenyl phosphate & .2 \\
\hline Carbaryl & .2 & Tris(dichlorisopropyl)phosphate & .20 \\
\hline Carbazole & .2 & Tris(2-butoxyethyl)phosphate & .2 \\
\hline Chlorpyrifos & .2 & Tris(2-chloroethyl)phosphate & .2 \\
\hline
\end{tabular}




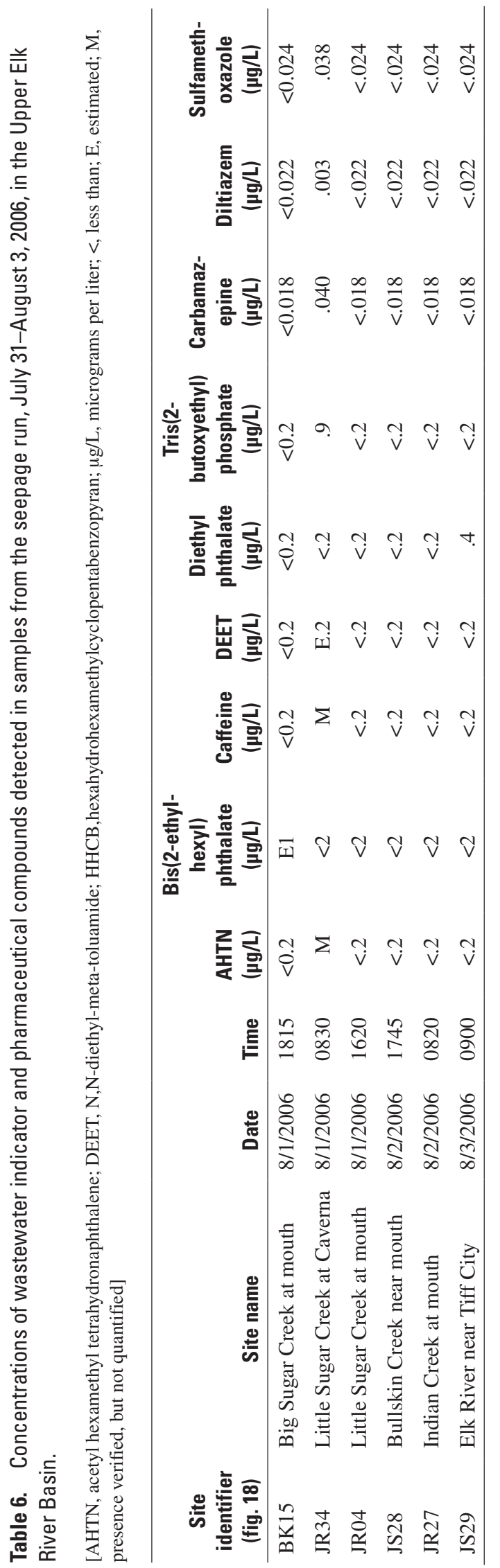

Discharge values measured during the second seepage run, November 13-14, 2006 (table 7; fig. 18) generally had increased from those measured in the first seepage run. The flow in Big Sugar Creek had more than doubled, had doubled in Little Sugar Creek, and had increased more than 30 percent in the Elk River.

Calcium concentrations in samples from the second seepage run ranged from 52.8 to $69.1 \mathrm{mg} / \mathrm{L}$ and were smallest in samples from Big Sugar Creek and the Elk River. Sodium, chloride, and sulfate concentrations were largest in samples from Little Sugar Creek and the Elk River (fig. 21), possibly indicating effects from effluent inflow into Little Sugar Creek and the Elk River.

E. coli densities were less than $85 \mathrm{col} / 100 \mathrm{~mL}$ in samples from the second seepage run; therefore, the Missouri waterquality criteria for whole-body-contact recreation was not exceeded, although the time of sample collection was after the recreational season. The maximum fecal coliform density was $260 \mathrm{col} / 100 \mathrm{~mL}$ from Little Sugar Creek at Missouri Road (site JR01).

Nitrate concentrations were less than $4.0 \mathrm{mg} / \mathrm{L}$ in all samples from the second seepage run (fig. 22). The largest concentration was detected in a sample from North Indian Creek (site JS19), a tributary to Indian Creek. The concentration in the sample from Indian Creek near Lanagan had decreased to less than $1.0 \mathrm{mg} / \mathrm{L}$. Nitrate concentrations in samples from Little Sugar Creek ranged from 0.88 (site JR82; near the mouth) to $2.60 \mathrm{mg} / \mathrm{L}$ ( site JR02; below Bella Vista); these concentrations were larger than those detected in the prior seepage run-0.102 (at the mouth) to $1.09 \mathrm{mg} / \mathrm{L}$ (below Bella Vista). The total phosphorus concentrations in samples from Little Sugar Creek below Bella Vista decreased from those detected in the first seepage run $(0.670 \mathrm{mg} / \mathrm{L})$ to 0.430 $\mathrm{mg} / \mathrm{L}$ in November 2006.

Seven pharmaceutical compounds were detected in samples from the second seepage run (table 7). Seven compounds were detected in the sample from Little Sugar Creek at Caverna, three from Little Sugar Creek near Pineville (site JR82), two from the Elk River below Noel (site Bk24), and one from Indian Creek near Lanagan (site JR06). All of these sites are located downstream from effluent inflow. No samples were collected for analysis of wastewater indicator compounds, optical brighteners, chlorophyll $a$, and nitrogen isotopes.

\section{Streambed-Sediment Quality}

Streambed-sediment samples were collected at 35 sites (table 8; fig. 23) throughout the Upper Elk River Basin in August 2005. Analytical and leaching results on individual streambed-sediment samples were grouped to facilitate spatial and statistical analyses of the data. Data from the samples were grouped to represent the major forks of the Elk River (Big and Little Sugar Creeks, Indian Creek, and the Elk River) or tributaries of the major forks (Big Sugar Creek tributaries, 


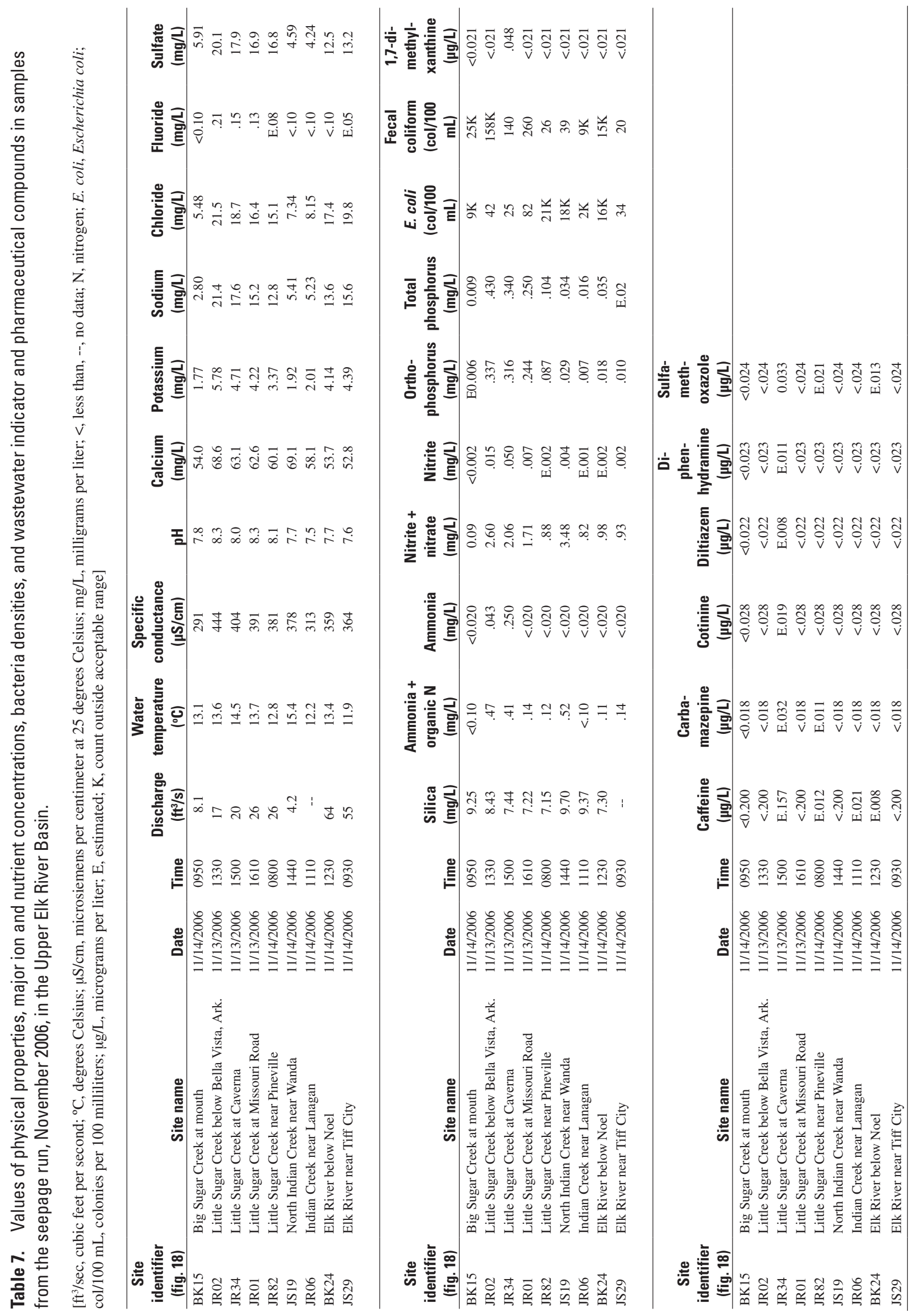




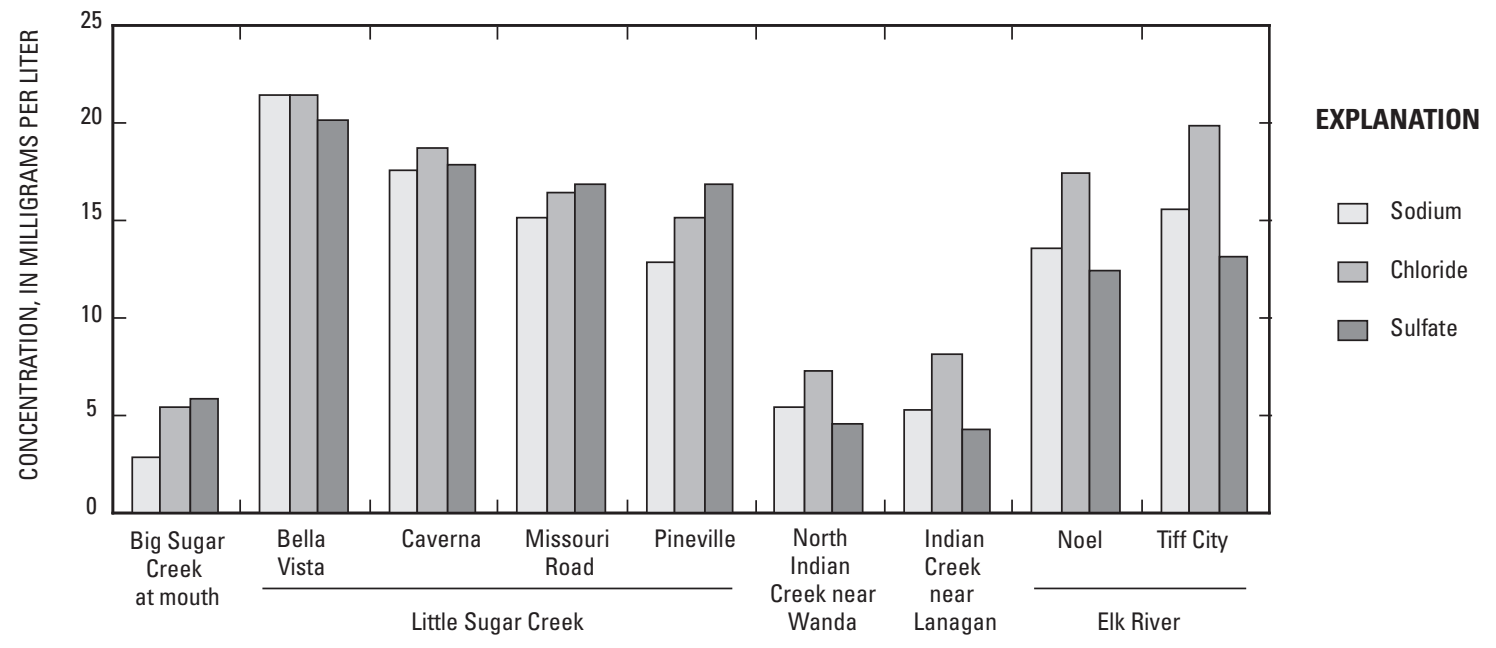

Figure 21. Sodium, chloride, and sulfate concentrations in samples from the seepage run, November 2006, in the Upper Elk River Basin.

Little Sugar Creek tributaries, Indian Creek tributaries, and the Elk River tributaries).

Concentrations of trace elements and other constituents in sediments often are normalized to improve the sensitivity of methods used to examine trends or patterns in the data (Horowitz, 1985; Luoma, 1990; Daskalakis and O'Connor, 1995). Normalization to grain-size or organic carbon content are two of the more commonly used factors, in addition to aluminum and iron content (Daskalakis and O'Connor, 1995). A Pearson pairwise correlation matrix between four factors (grain-size, organic carbon, aluminum, and iron content) in streambed-sediment samples and nutrient concentrations in the leachate samples indicated that organic carbon content was most highly correlated with nutrient concentrations (table 8). Therefore, nutrient concentrations in leachate samples were normalized to sediment organic carbon content using the following relations:

$\mathrm{C}_{\text {adj }}=\mathrm{C}_{\text {leachate }} *(100 /$ percent organic carbon content $)$ Step 1

$\mathrm{C}_{\text {scaled }}=\mathrm{C}_{\text {adj }} /$ (maximum $\mathrm{C}_{\text {adj }}$ calculated in all samples) Step 2

where $\mathrm{C}_{\text {adj }} \quad$ is the nutrient concentration in the leaching experiment adjusted for organic carbon content;

$\mathrm{C}_{\text {leachate }} \quad$ is the initial nutrient concentration in the leachate solution; and

$\mathrm{C}_{\text {scaled }} \quad$ is the final leachate concentration normalized to the maximum value reported for each constituent in all samples.

Normalization concentrations for each individual nutrient were then scaled by dividing by the largest $\mathrm{C}_{\text {adj }}$ value calculated for all samples. This resulted in normalized nutrient concentrations ranging from 0 to 1.0 that were then used in the statistical analysis. The reporting limit was used for concentrations with "less than" values.

Concentrations of one or more nutrients were detected in all sediment leachate samples (table 8). The most frequently detected and at the largest concentrations was dissolved ammonia plus organic nitrogen as nitrogen (hereinafter referred to as ammonia plus organic nitrogen), which was detected in all leachate samples at concentrations ranging from 0.80 to $15.0 \mathrm{mg} / \mathrm{L}$. Smaller concentrations of dissolved ammonia as nitrogen (hereinafter referred to as ammonia) were detected in all leachate samples at concentrations ranging from 0.02 to $2.23 \mathrm{mg} / \mathrm{L}$. All leachate samples contained detectable concentrations of dissolved phosphorus and dissolved orthophosphorus at concentrations ranging from 0.08 to $1.58 \mathrm{mg} / \mathrm{L}$ and 0.02 to $1.19 \mathrm{mg} / \mathrm{L}$ (table 8 ). In contrast, only 16 leachate samples contained detectable concentrations of dissolved nitrite plus nitrate as nitrogen (hereinafter referred to as nitrate) at concentrations ranging from $0.03 \mathrm{mg} / \mathrm{L}$ to 0.17 $\mathrm{mg} / \mathrm{L}$. Concentrations of dissolved nitrite were detected in only nine samples at concentrations equal to or less than 0.017 $\mathrm{mg} / \mathrm{L}$.

To minimize variance caused by differences in sediment grain-size or other factors, statistical analysis of the leaching data was done using normalized (to sediment organic carbon content) and scaled values. Concentrations of leachable nutrients normalized to organic carbon content generally tended to be slightly larger along the major forks of the Elk River compared to tributary sites, with sites in the upper reaches of the major forks having among the largest concentrations (fig. 23). Normalized concentrations of leachable nutrients in the major forks generally decreased with increasing distance downstream. The largest normalized leachable nutrients concentrations were from sites along Big Sugar Creek (sites 29 and 35), Little Sugar Creek (site 5) or Elk River (site 11A). Big Sugar Creek near Cyclone (site 29) had the largest normalized leach- 


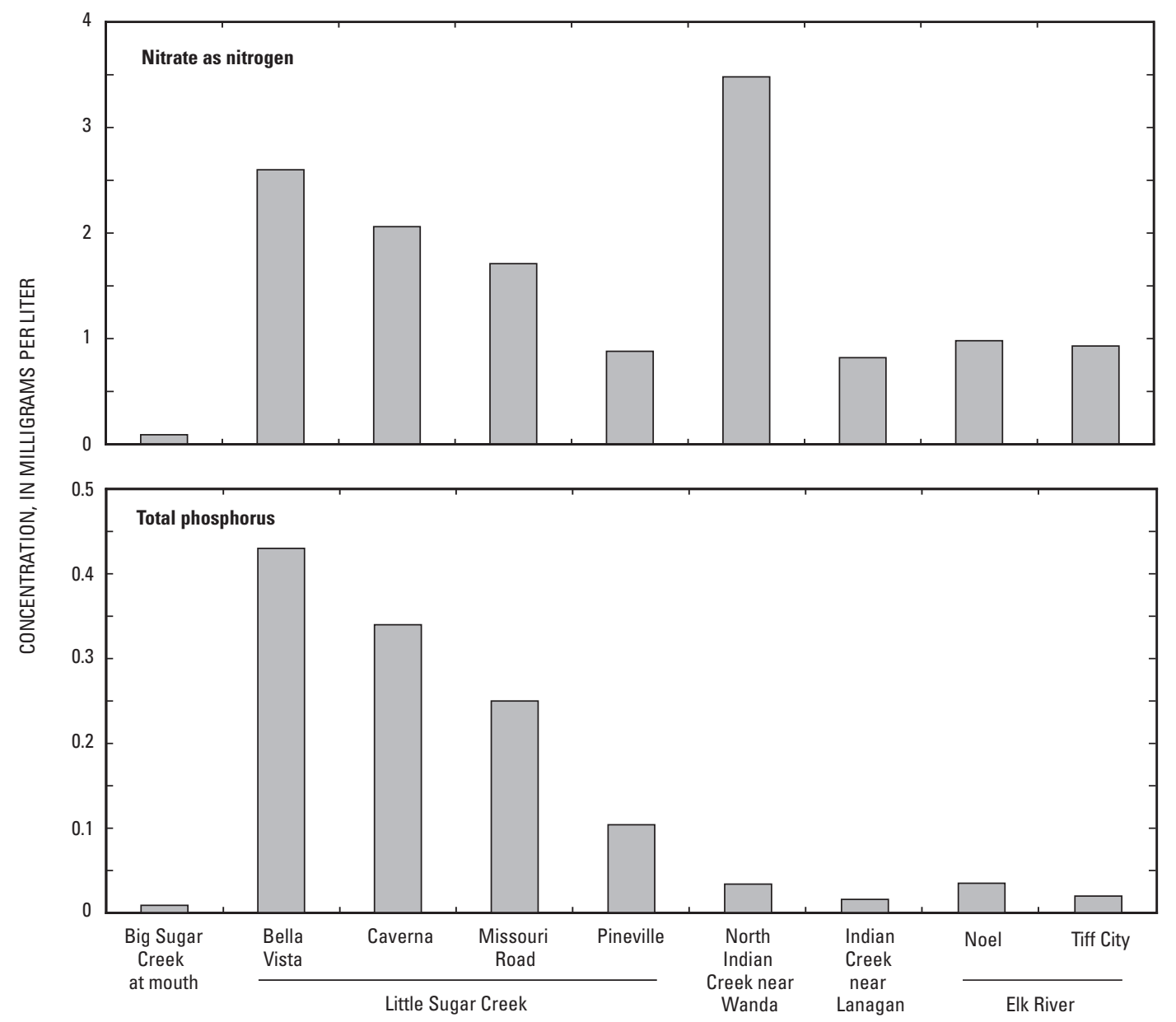

Figure 22. Nutrient concentrations in samples from the seepage run, November 2006, in the Upper Elk River Basin.

able phosphorus and ammonia plus organic nitrogen and the second largest normalized leachable orthophosphorus concentrations (table 8). Little Sugar Creek near Bella Vista (site 5) had the largest normalized leachable orthophosphorus and second largest normalized leachable phosphorus concentrations. The largest normalized leachable ammonia concentration detected was from the Elk River near Noel (site 11A). An overall ranking of sites based on summing the normalized leachable nutrient concentrations (ammonia plus organic nitrogen, ammonia, phosphorus, and orthophosphorus) indicated that the largest leachable nutrient concentrations were from Big Sugar Creek near Cyclone (site 29), Little Sugar Creek near Bella Vista (site 5), and the Elk River near Noel (site 11A).

No significant difference in leachable nutrient concentrations normalized to organic carbon between the sample groups (fig. 24) was indicated. The p-values using Tukey's multiple comparison test were greater than 0.13 for all nutrients, except for normalized orthophosphorus concentrations, which was marginally significant at the 10 percent level with a p-value of 0.10 . The p-value is the probability of erroneously reporting a difference when no difference actually exits. Results were considered significant if $\mathrm{p}$-values were less than 0.10 .
Whereas concentrations of leachable ammonia plus organic nitrogen and ammonia in the three major forks of the Elk River were similar, concentrations of phosphorus and orthophosphorus tended to be larger in Little Sugar Creek than in the other two major forks (fig. 23). Results of Tukey's pairwise comparison using only data from the three major forks of Elk River (Big Sugar Creek, Little Sugar Creek, and Indian Creek) indicated that leachable orthophosphorus concentrations in Little Sugar Creek were significantly larger than in Indian Creek ( $\mathrm{p}=0.03$ ), but not significantly larger than concentrations in Big Sugar Creek ( $\mathrm{p}=0.12$ ).

Normalized concentrations of phosphorus and orthophosphorus in tributaries to Little Sugar Creek were significantly smaller than those from the main stem of Little Sugar Creek (p-values of 0.04 and 0.03). No significant differences were detected between main stem and tributary sites along Big Sugar Creek, Indian Creek, or the Elk River. The largest normalized leachable nutrient concentrations detected in tributary sites were at site 23A (South Indian Creek near Boulder City) followed by site 1A on Bear Creek near Caverna (tributary of Little Sugar Creek) and site 36 on Otter Creek near Jacket (tributary of Big Sugar Creek). 

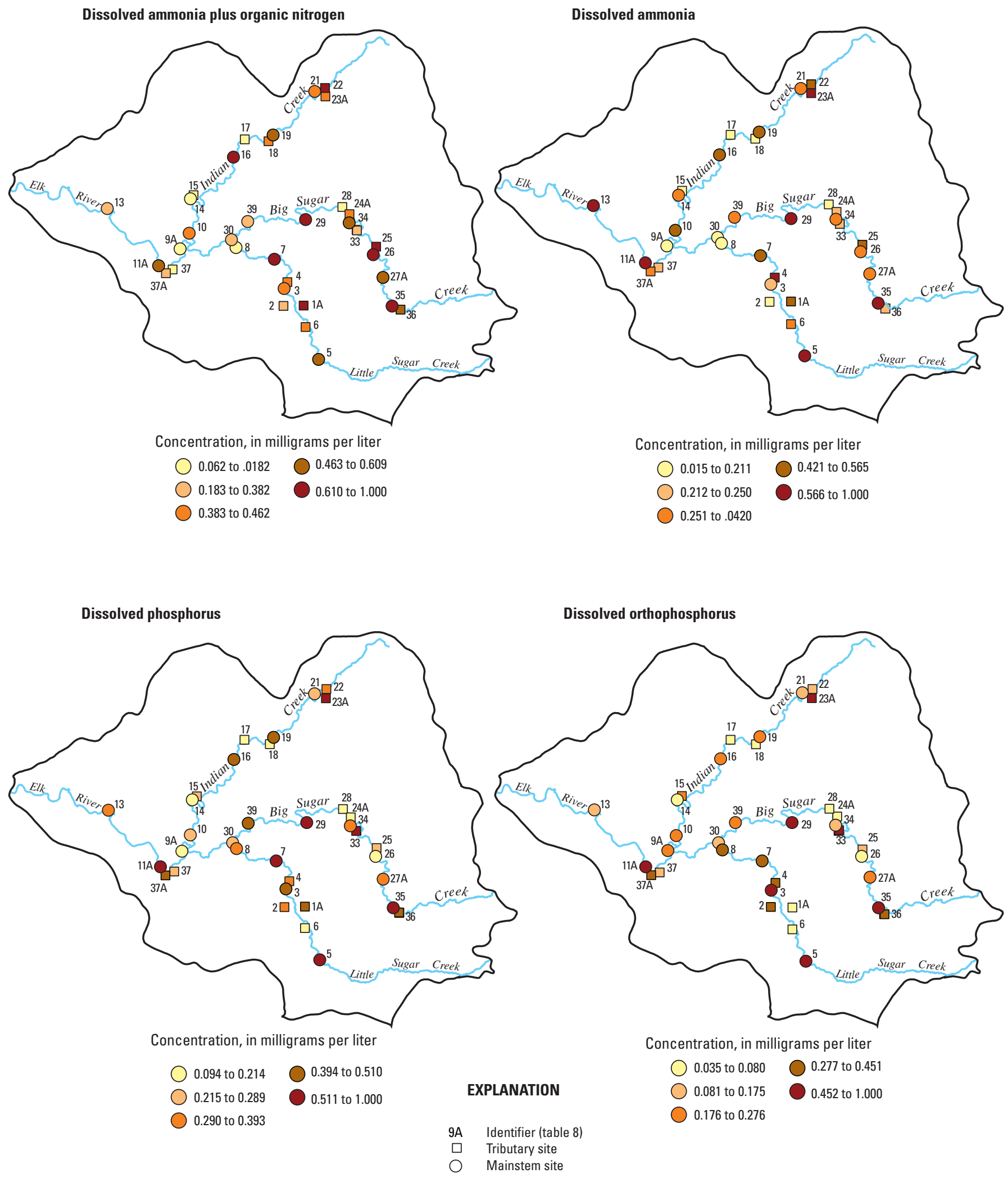

NOTE: Concentrations scaled to maximum value

Figure 23. Concentrations of leachable nutrients normalized to organic carbon content in strambed-sediment samples, in the Upper Elk River Basin, August 2005. 


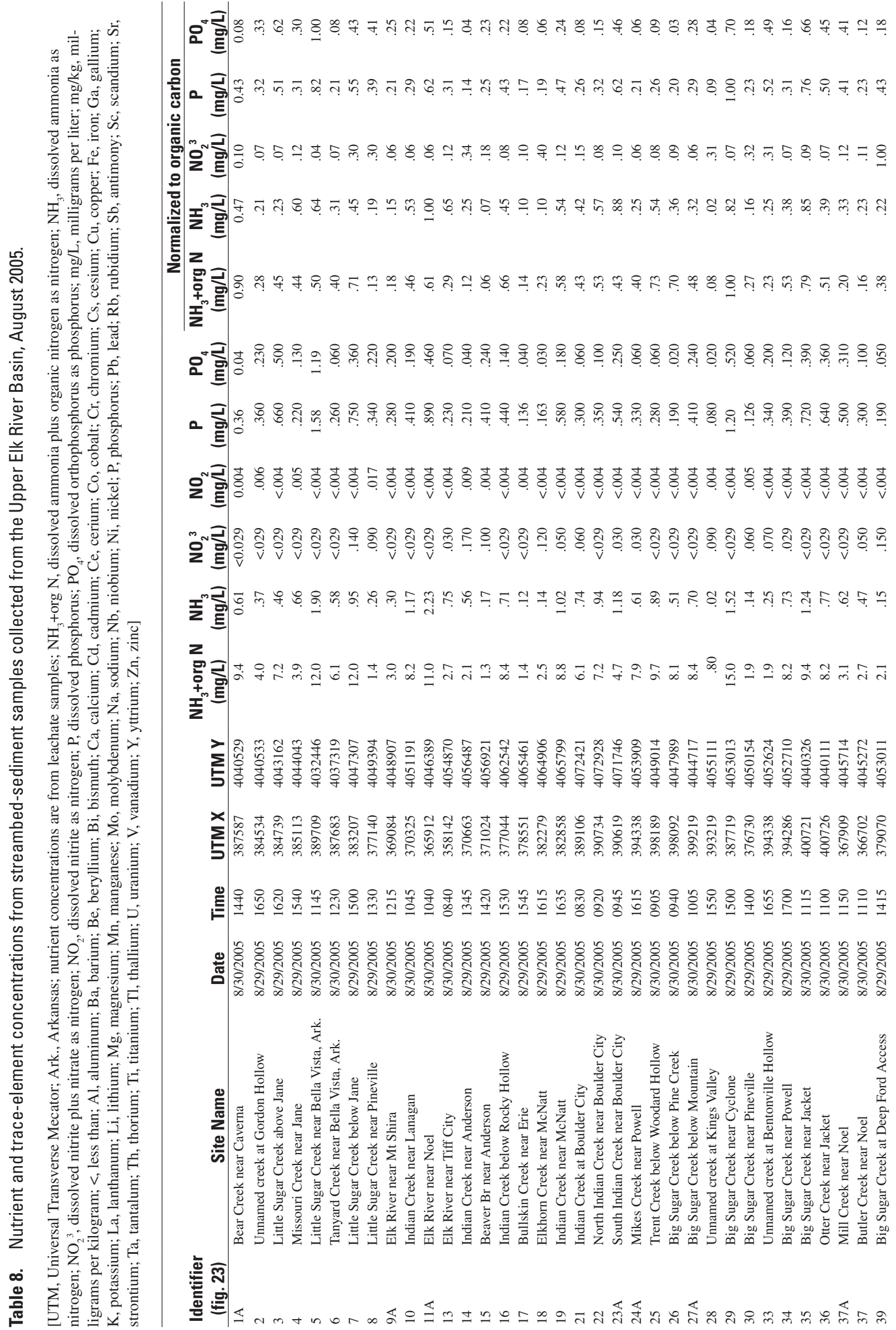




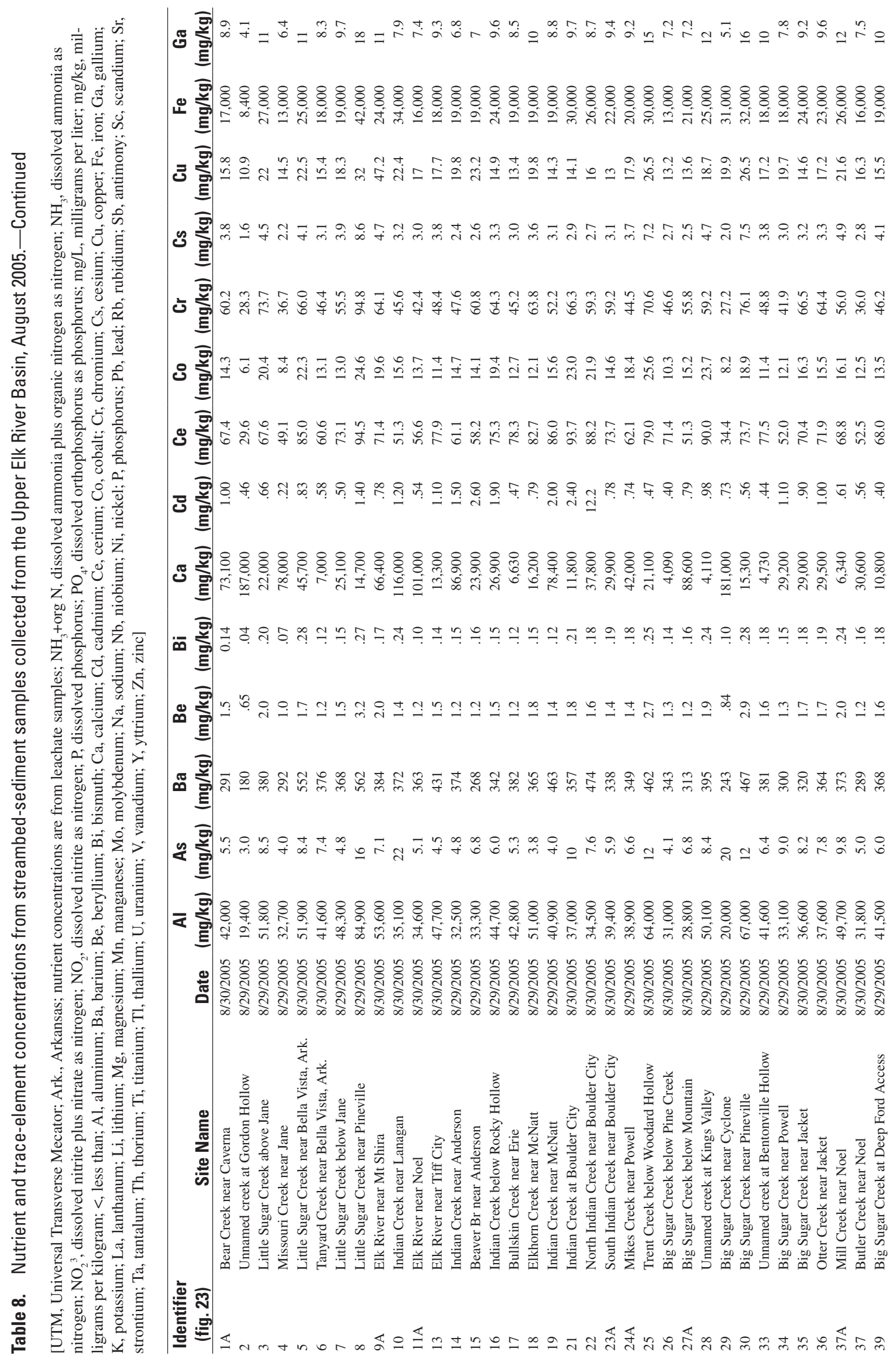




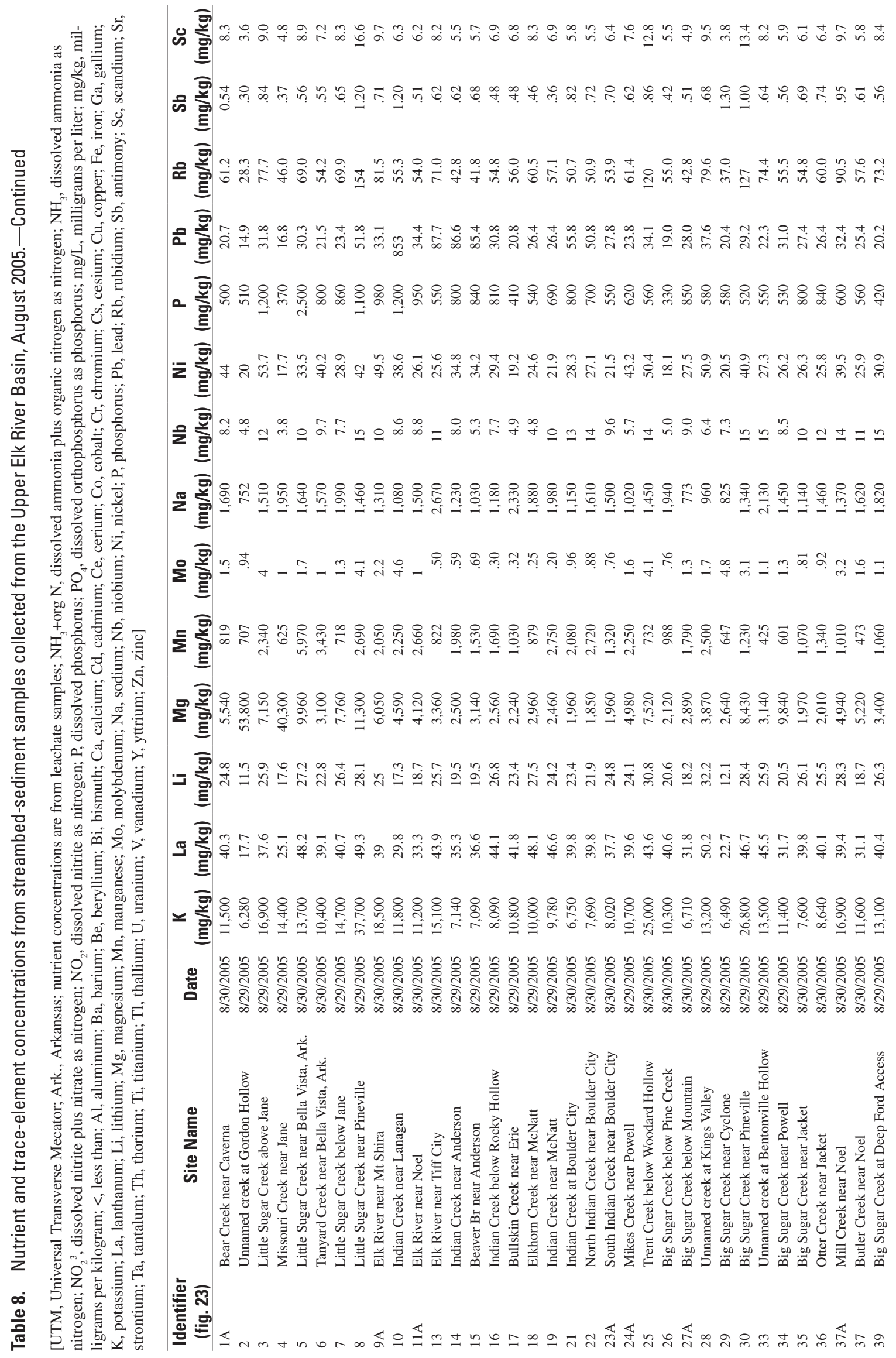



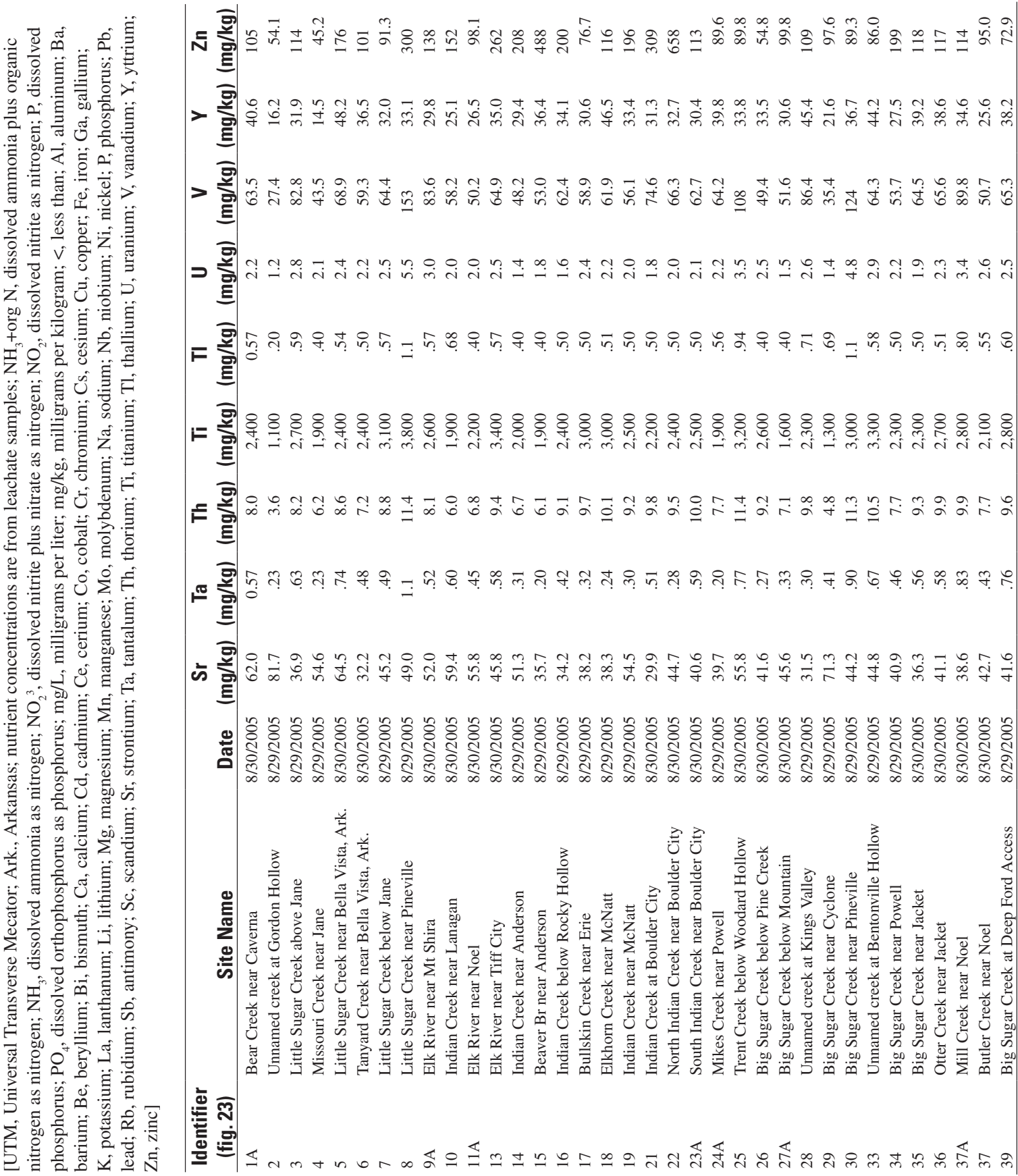

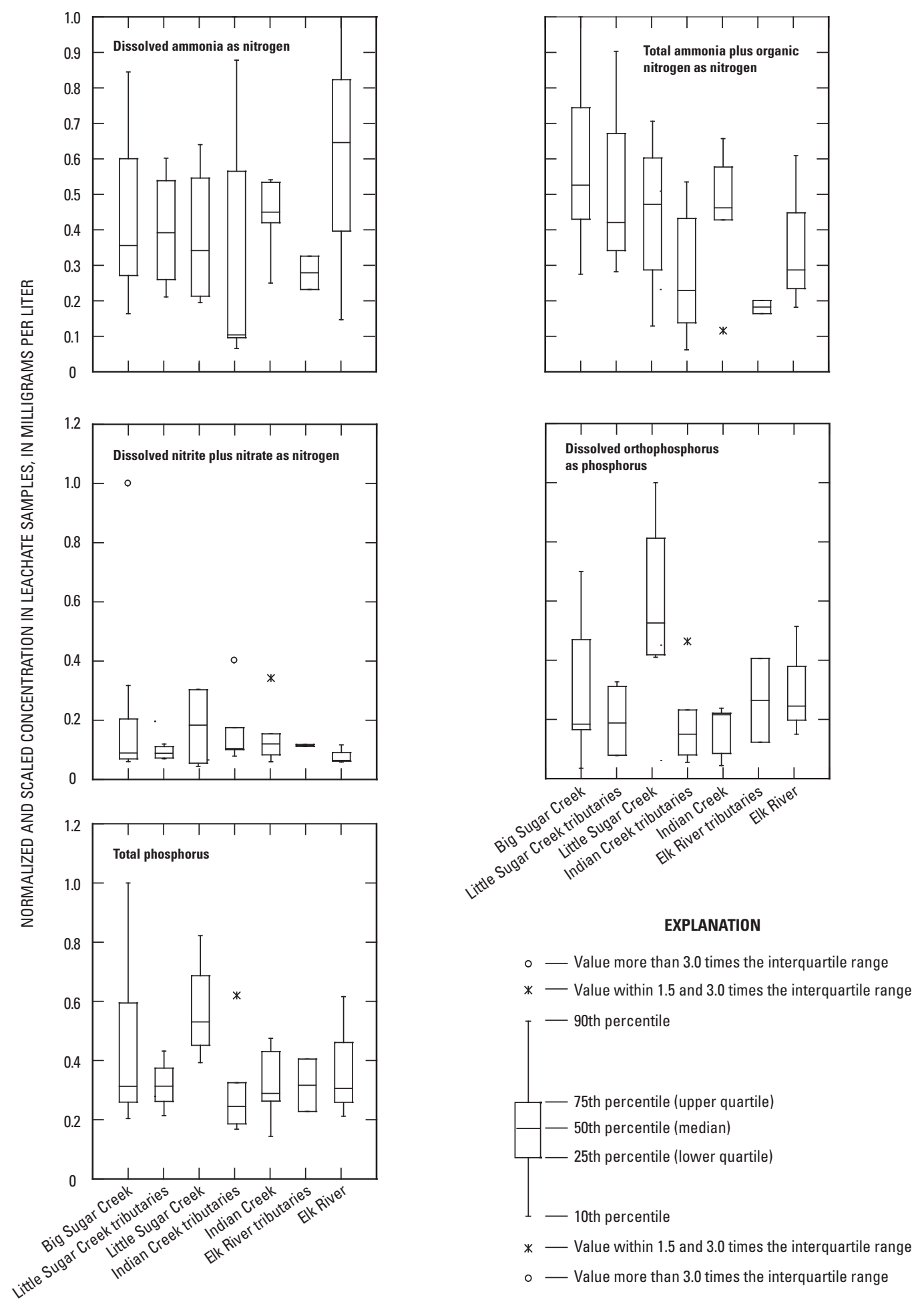

Figure 24. Concentrations of selected nutrients in leachate samples normalized to organic carbon content in streambed-sediment samples in the Upper Elk River Basin, August 2005. 


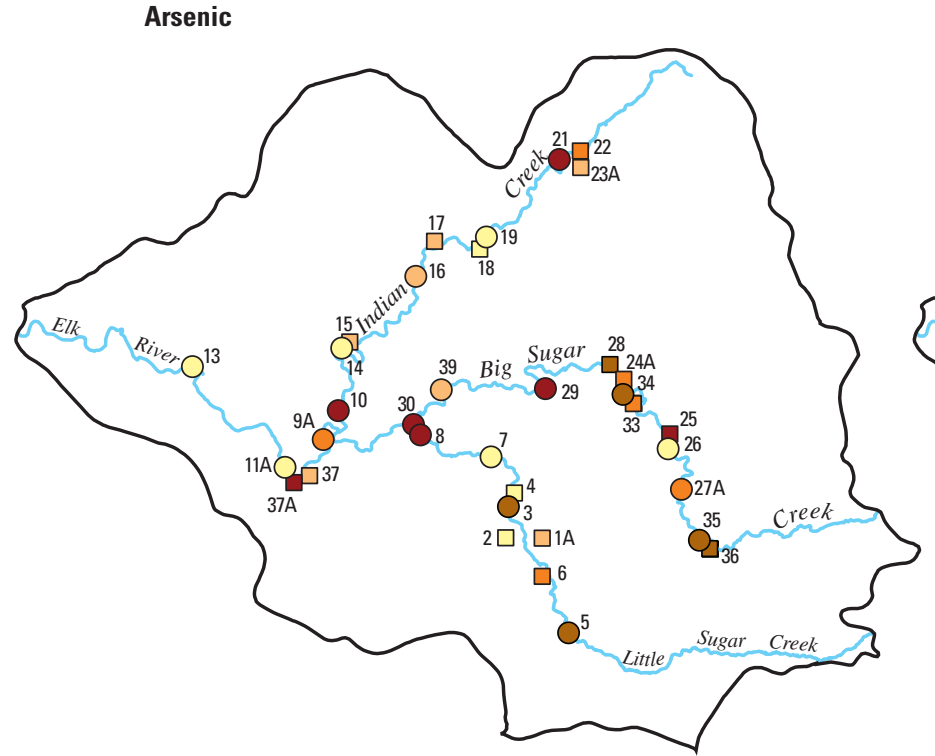

Concentration, in milligrams per kilogram

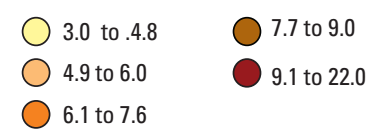

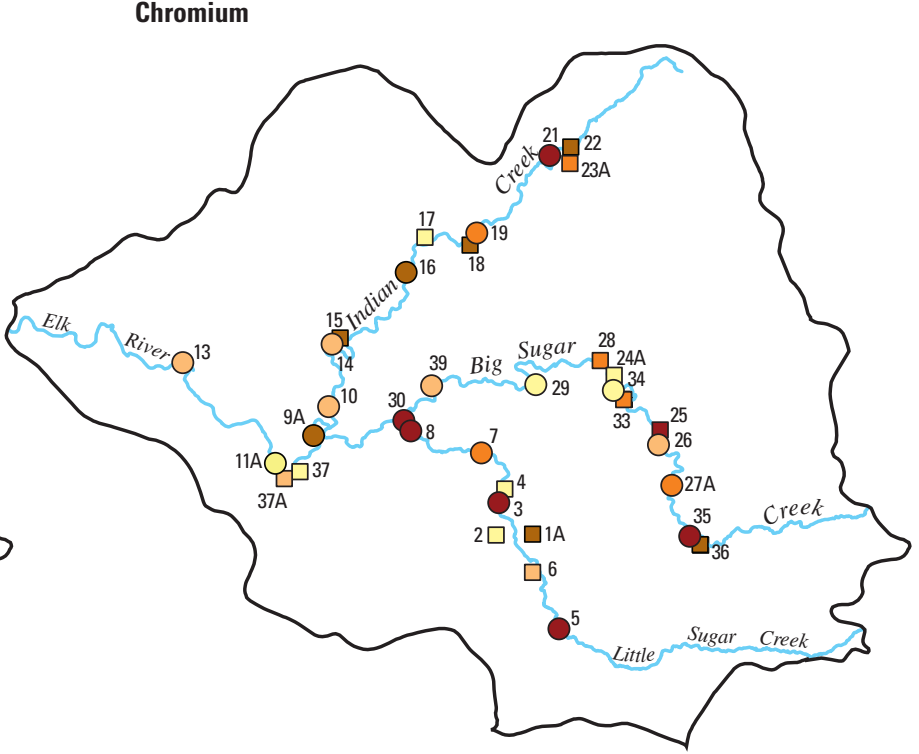

Concentration, in milligrams per kilogram

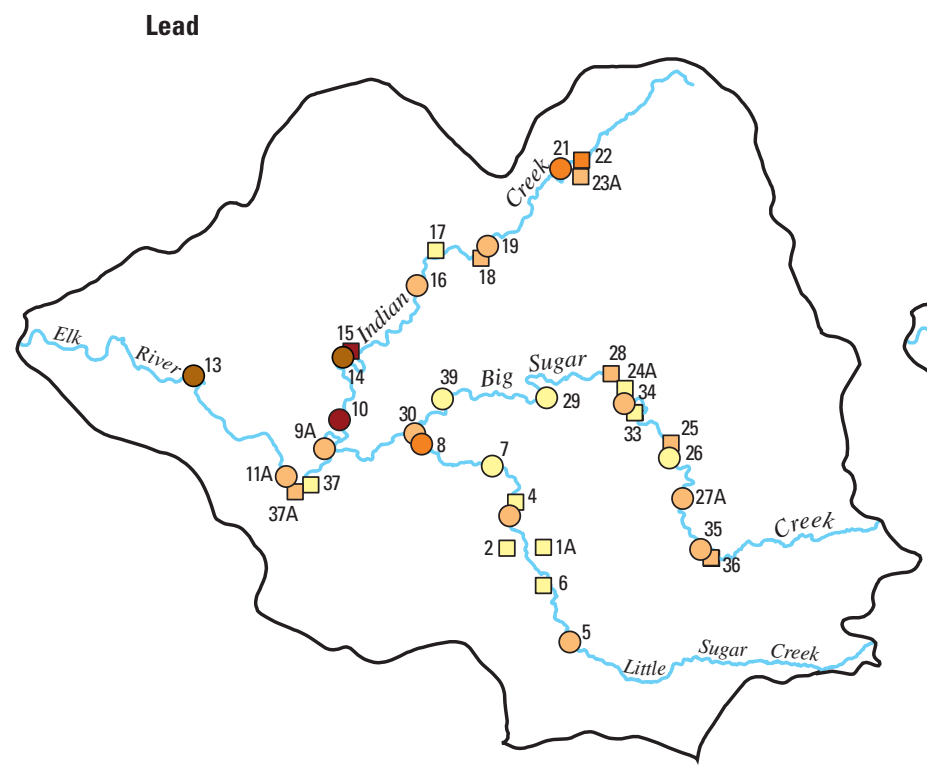

Concentration, in milligrams per kilogram

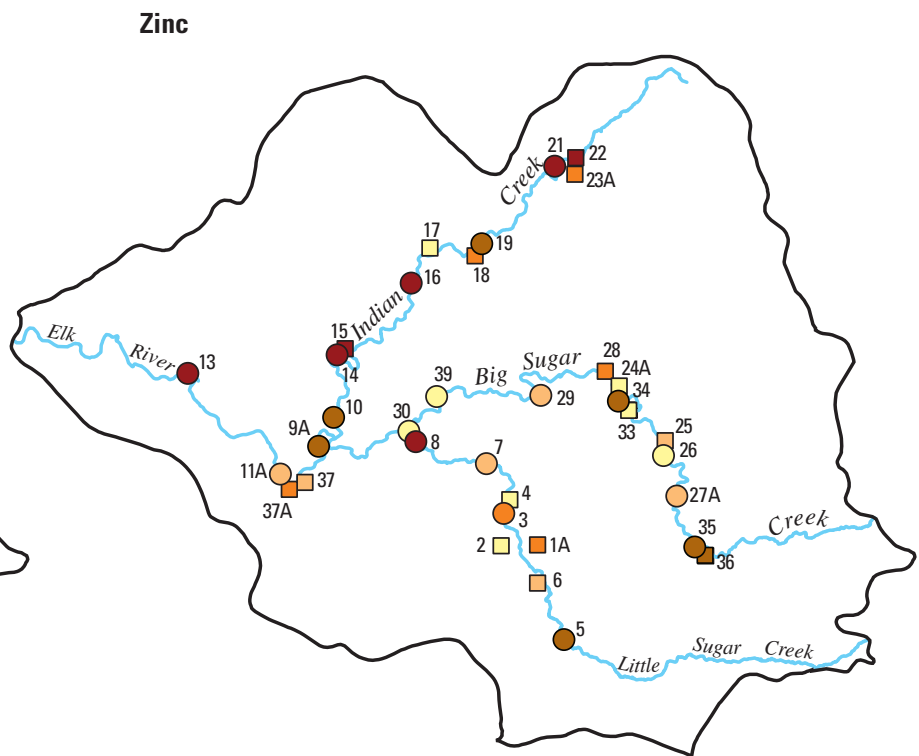

Concentration, in milligrams per kilogram
14.9 to 25.4
55.9 to 87.7
25.5 to 37.6
87.8 to 853
37.7 to 55.8

EXPLANATION

0 to 44.5

44.6 to $48.8 \quad 64.5$ to 94.8

48.9 to 59.2

NOTE: Concentrations scaled to maximum value

Figure 25. Concentrations of selected trace elements normalized to organic carbon content in streambed-sediment samples in the Upper Elk River Basin, August 2005. 

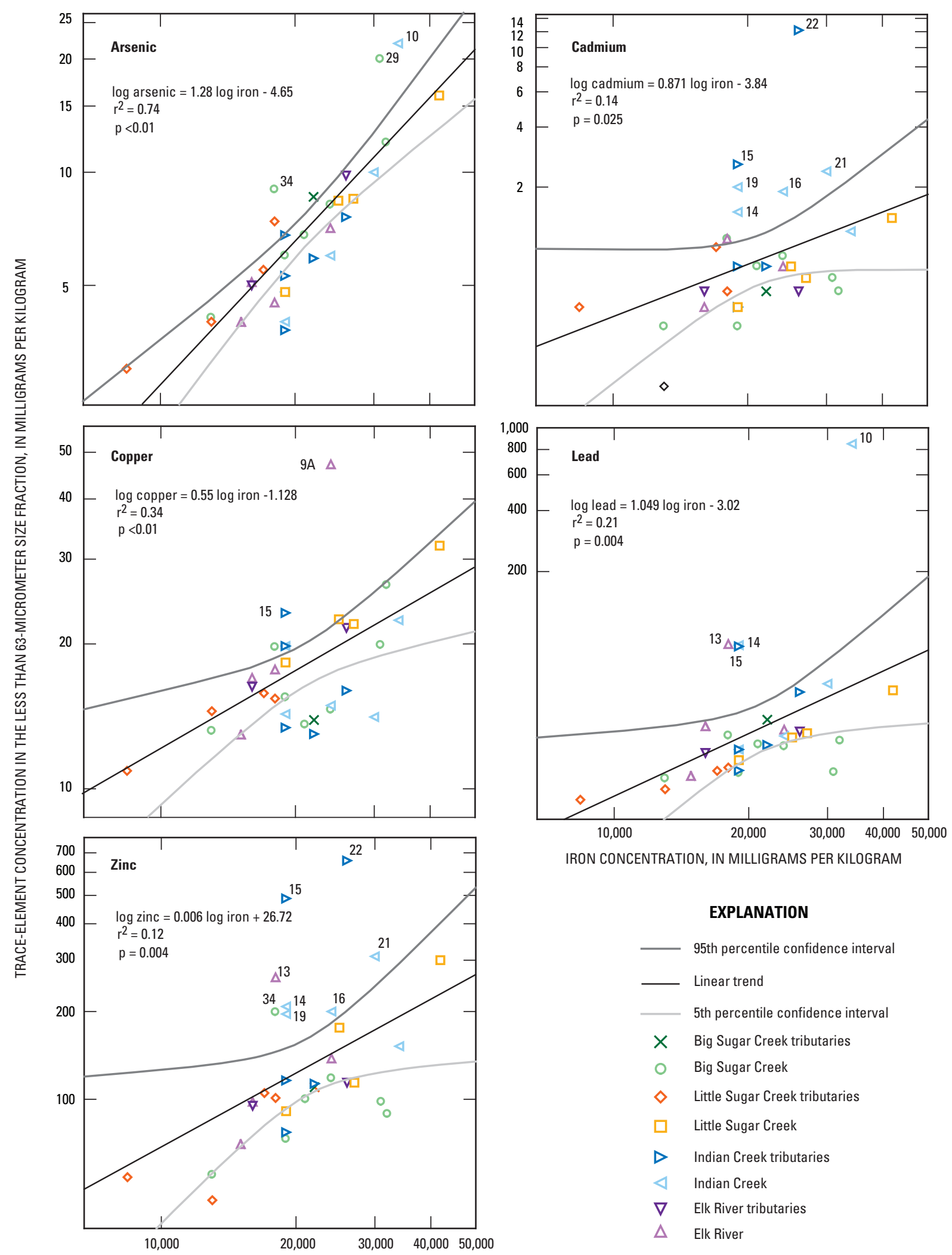

IRON CONCENTRATION, IN MILLIGRAMS PER KILOGRAM

\section{EXPLANATION}

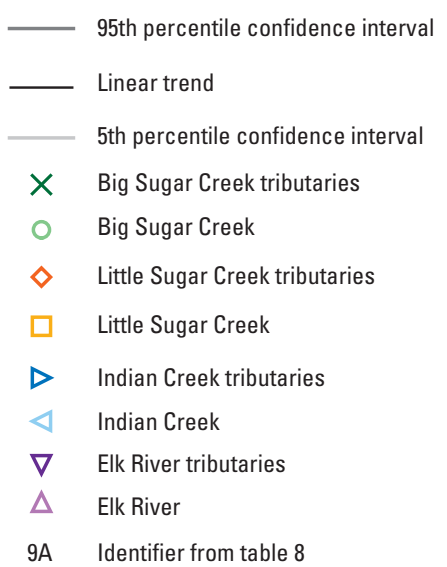

Figure 26. Relation of selected trace-element concentrations and iron in the less than 63-micrometer size fraction of streambed-sediment samples from the Upper Elk River Basin, August 2005. 


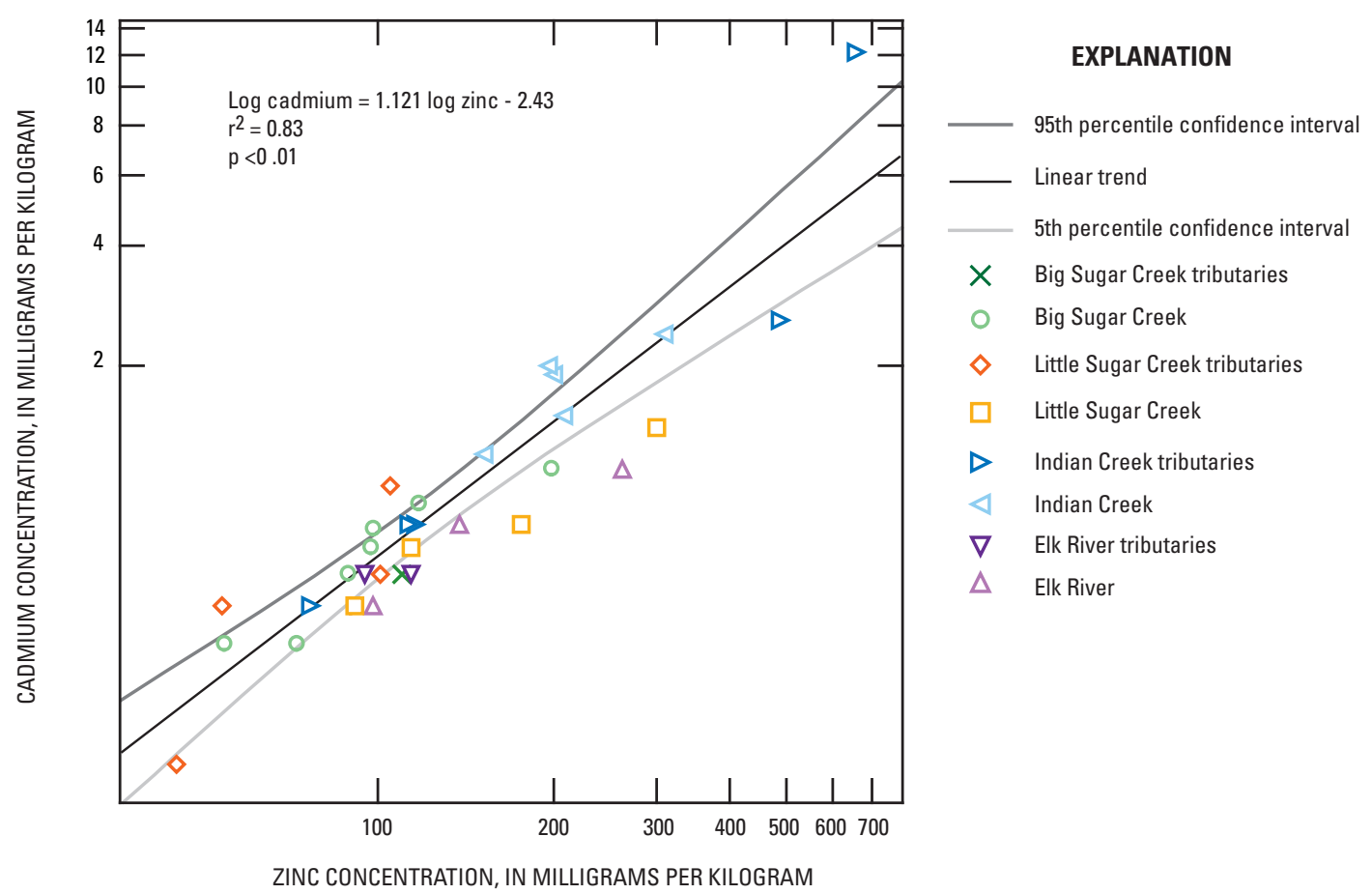

Figure 27. The trend of cadmium and zinc in streambed-sediment samples in the Upper Elk River Basin, August 2005.

Concentrations of trace elements in sediments vary widely depending upon the geologic material from which they are derived. This natural variability complicates determining if trace-element concentrations are larger than naturally occurring background concentrations. However, many trace elements in sediment are associated with the iron-oxides and strong correlations exist between their concentrations and iron (Hem, 1985). This natural positive relation between trace-element and iron concentrations can be utilized to identify increased trace-element concentrations from manmade or anthropogenic sources. Mahler (2003) illustrated this relation graphically by showing that sediment samples with naturally occurring trace-element concentrations plotted along a linear trend. Samples that plotted above the linear trend (larger than expected trace-element concentration) were suspected of being affected from anthropogenic sources.

Concentrations of trace elements in streambed-sediment samples from the Elk River Basin (fig. 25) generally correlated well with iron concentrations (fig. 26), indicating mostly non-anthropogenic (or natural) sources for most trace elements. Several outliers plotting substantially above the general trends were lead at site 10 and cadmium at site 22. Site 10 (Indian Creek near Lanagan) is immediately downstream from Lanagan, and the lead concentration of 853 milligrams per kilogram $(\mathrm{mg} / \mathrm{kg})$ is likely the result of anthropogenic contamination, possibly from urban sources from within Lanagan. Site 22 is along North Indian Creek about 1 river mile upstream from Boulder City.

Samples from two of the five tributary sites (sites 15 and 22) and four of the five main stem (sites 14, 16, 19, and 21) sampling sites along Indian Creek plot above the general trend of cadmium and iron (fig. 26). Although above the general trend line, concentrations of cadmium in streambedsediment samples at all sites were less than $15 \mathrm{mg} / \mathrm{kg}$. The larger than expected cadmium concentrations at site 22 and other sites within the Indian Creek Basin possibly are related to geology. The Elk River Basin lies just south of the historical Tri-State Lead-Zinc Mining District, and some abandoned shallow mine workings are located within the upper part of the North Indian Creek Basin, about $4 \mathrm{mi}$ upstream from site 22. One of the major ore minerals in the district was sphalerite $(\mathrm{ZnS})$, which contains considerable amounts of cadmium. Concentrations of cadmium in streambed sediments are strongly correlated with zinc, and samples from Indian Creek and its tributaries have among the largest cadmium and zinc concentrations (fig. 27). Indian Creek sediments have significantly larger cadmium, lead, and zinc $(\mathrm{p}<0.01, \mathrm{p}=0.06$, and 0.02$)$ concentrations than sediments in Big Sugar Creek. Concentrations of cadmium in sediments in Indian Creek also were significantly larger than in sediments from Little Sugar Creek $(\mathrm{p}<0.01)$. 


\section{Summary}

The U.S. Geological Survey, in cooperation with the Missouri Department of Natural Resources, collected samples in the Upper Elk River Basin in southwestern Missouri and northwestern Arkansas from October 2004 through September 2006 (one set of stormwater samples was collected in late November and early December 2006) to determine the water quality and streambed-sediment quality. Water-quality samples were collected monthly, during selected storms, and during low-base flow conditions; streambed-sediment samples were collected one time.

The Elk River Basin encompasses more than 1,000 square miles in parts of Missouri, Arkansas, and Oklahoma. It is in the Springfield Plateaus physiographic section of the Ozark Plateaus physiographic province. The slightly rolling hills contain numerous karst features (sinkholes, caves, and springs) that transport surface water through solution-enlarged joints and fractures. Land use in the Elk River Basin is equally divided between forest and pasture. Confined animal feeding operations in McDonald County account for the second largest concentration of poultry in Missouri, with an estimated 6 million broilers and other meat-type chickens. Poultry operations are throughout the basin, but tend to be denser in the Indian Creek Basin. The population of McDonald County in 2005 is estimated to be 22,844, an increase of 35 percent since 1990 .

In 1998, the Missouri Department of Natural Resources included a 21.5-mile river reach of the Elk River on the 303(d) list of impaired waters in Missouri as required by Section 303(d) of the Federal Clean Water Act. The Elk River is on the 303(d) list for excess nutrient loading.

The nitrate as nitrogen (nitrate) concentrations from historical water-quality samples (data collected before October 2004) were similar for sites on Little Sugar Creek and the Elk River. Concentrations of total phosphorus in historical samples were significantly larger in samples from Little Sugar Creek.

The distribution of total phosphorus in historical samples from the Elk River near Tiff City was significantly different for samples before 1985 and after 1985. The pre-1985 mean total phosphorus concentration was 0.064 milligram per liter, and the post-1985 mean total phosphorus concentrations was 0.093 milligram per liter. In the Upper Elk River Basin in Missouri, the yearly average number of poultry increased by 189 percent since 1985 when compared to the number before 1985. The total phosphorus concentrations increased in samples from the Elk River near Tiff City; the last increase was from 2000 through 2003. The total phosphorus distribution by decade indicates that the concentrations since 2000 have increased significantly from those in the 1960s, 1980s, and 1990s.

Nitrate concentrations also have significantly increased in post-1985 samples compared to pre-1985 samples in the Elk River near Tiff City. Median nitrate concentrations increased from 0.880 milligram per liter before 1985 to 1.44 milligram per liter after 1985. Concentrations have increased signifi- cantly since the 1960s. Concentrations in the 1970s and 1980s, though similar, had increased from those in the 1960s, and the concentrations from the 1990s and 2000s increased still more.

Nitrate concentrations significantly increased in samples that were collected during larger discharges (greater than 355 cubic feet per second) from the Elk River near Tiff City as compared to the concentrations in samples collected during smaller discharges.

Data collected by the U.S. Geological Survey from October 2004 through December 2006 indicate the following:

* Nitrate concentrations were largest in Indian Creek. Several sources of nitrate are present in the basin, including poultry facilities in the upper part of the basin, effluent inflow from communities of Anderson and Lanagan, land-applied animal waste, chemical fertilizer, and possible leaking septic systems.

* The total phosphorus concentrations were largest in Little Sugar Creek. The median concentration in samples from Little Sugar Creek below Caverna was more than eight times the median concentration in samples from the Elk River near Tiff City; the median concentration from samples from Little Sugar Creek near Pineville was almost four times the median concentration in samples from the Elk River near Tiff City.

* In the Upper Elk River Basin, the largest median nitrate load was carried by the Elk River near Tiff City. The loads increased downstream in the basin. Little Sugar Creek below Caverna and the Elk River near Tiff City carried the largest total phosphorus load.

* Nitrate concentrations tended to increase with increasing discharge. Concentrations increased near the beginning of the ambient sample collection in November 2004 and continued to increase through January 2005, when they began to rather substantially decrease through the summer, fall, and winter of 2005 along with a corresponding decrease in discharge. Runoff from livestock operations or fertilizer applied to lawns or fields can contribute to the increased nitrate concentrations. Total phosphorus concentrations tended to be inversely related to discharge. Some of the largest concentrations at Little Sugar Creek near Pineville were in samples collected at some of the smallest discharges, indicating point sources of the nutrient.

* Median concentrations of nutrient species were greater in the stormwater samples than the median concentrations of the ambient samples. The nitrate concentrations in stormwater samples ranged from 133 to 179 percent of the concentration in the ambient samples. The total phosphorus concentrations in the stormwater samples ranged from about 200 to more than 600 percent of the concentration in the ambient samples. Small concentrations of nutrients carried in large storm flows can deliver extremely large loads of nutrients. For example, the total phosphorus load in the samples from the November 2004 storm at the Elk River near Tiff City was 26 percent of the load of the ambient samples collected from October 2004 through September 2006.

* Nitrogen isotope samples were collected during selected storms. The value from Big Sugar Creek near Powell 
is in the range of animal manure and human sewage. Because no sewage inflow is permitted for this stream, this $\delta^{15} \mathrm{~N}$ values indicates animal sources. The source of the $\delta^{15} \mathrm{~N}$ from Little Sugar Creek, with a nitrogen isotope value of +11.21 per mil, is in the range of human sewage and animal manure. Based on effluent inflow into Little Sugar Creek from Bella Vista, Ark., the value probably is indicative of human sources. The $\delta^{15} \mathrm{~N}$ values for May 2006 for Little Sugar and Indian Creeks were each about +7.0 per mil, indicating human or animal sources, or a combination of both.

* Base-flow conditions as reflected by the seepage run of the summer of 2006 indicate that 52 percent of the discharge in the Elk River near Tiff City is contributed by Indian Creek. Little Sugar Creek contributes 32 percent and Big Sugar Creek 9 percent of the discharge in the Elk River near Tiff City. Only about 7 percent of the discharge at Tiff City comes from the mainstem of the Elk River.

* Nitrate concentrations in two of the three springs sampled in the Indian Creek Basin during the seepage run in the summer of 2006 were some of the largest detected during this study-4.34 and 11.1 milligrams per liter. Livestock production facilities in the Upper Elk River Basin are concentrated in the upper reaches of the Indian Creek Basin. Total phosphorus concentrations were largest in the upper reaches of the Little Sugar Creek Basin downstream from Bella Vista, Arkansas, with a trend of generally decreasing concentrations to the mouth of Little Sugar Creek.

* Concentrations of dissolved ammonia plus organic nitrogen as nitrogen, dissolved ammonia as nitrogen, dissolved phosphorus, and dissolved orthophosphorus were detected in all sediment leachate samples.

* Concentrations of leachable nutrients normalized to organic carbon content generally tended to be slightly larger along the major forks of the Elk River as compared concentrations in samples from tributary sites, with sites in the upper reaches of the major forks having among the largest concentrations. Concentrations of leachable nutrients in the major forks generally decreased with increasing distance downstream. The largest normalized leachable nutrients concentrations were from sites on Big Sugar Creek, Little Sugar Creek, and the Elk River. Concentrations of dissolved phosphorus and dissolved orthophosphorus tended to be larger in Little Sugar Creek than in samples from other sites.

\section{References Cited}

Akaike, H., 1981, Likelihood of a model and information criterion: Journal of Econometrics, v. 16. p. 3-14.

Brown, G.K., Zaugg, S.D., and Barber, L.B., 1999, Wastewater analysis by gas chromatography/mass spectrometry, in Morganwalp, D.W., and Buxton, H.T., eds,, U.S. Geological Survey Toxic Substances Hydrology Program-Proceedings of the Technical Meeting, Charleston, South Carolina,
March 8-12, 1999: U.S. Geological Survey Water-Resources Investigations Report 99-4018B, v. 2, p. 431-436.

Casciotti, K.L., Sigman, D.M., Hastings, M., Böhlke, J.K., and Hilkert, A., 2002, Measurement of the oxygen isotopic composition of nitrate in seawater and freshwater using the denitrifier method: Analytical Chemistry, v. 74, p. 4,905-4,912.

City-Data.com, 2007, Arkansas and Missouri cities: accessed July 2007 at URL http://www.city-data.com/city/ Arkansas[Missouri].html

Coplen, T.B., Böhlke, J.K., and Casciotti, K.L., 2004, Using dual-bacterial denitrification to improve delta- $15 \mathrm{~N}$ determinations of nitrates containing mass-independent 17-O: Rapid Communications in Mass Spectrometry, v. 18, p. $245-250$.

Daskalakis, K.D., and O'Connor, T.P., 1995, Normalization and elemental sediment contamination in the coastal United States: Environmental Science and Technology, v. 29, p. $470-477$.

Davis, J.V., and Barr, M.N., 2006, Assessment of possible sources of microbiological contamination in the water column and streambed sediment of the Jacks Fork, Ozark National Scenic Riverways, Missouri-Phase III: U.S. Geological Survey Scientific Investigations Report 2006-$5161,32 \mathrm{p}$.

Davis, J.V., and Schumacher, J.G., 1992, Water-quality characterization of the Spring River Basin, Southwestern Missouri and Southeastern Kansas: U.S. Geological Survey WaterResources Investigations Report 90-4176, 112 p.

Edwards, T.K., and Glysson, G.D., 1998, Field methods for measure of fluvial sediment: U.S. Geological Survey Techniques of Water-Resources Investigations, book 3, chap. C2, $80 \mathrm{p}$.

Fenneman, N.M., 1938, Physiography of eastern United States: New York, McGraw-Hill Book Co., Inc., 689 p.

Fishman, M.J., ed., 1993, Methods of analysis by the U.S. Geological Survey National Water Quality Laboratory-Determination of inorganic and organic constituents in water and fluvial sediments: U.S. Geological Survey Open-File Report 93-125, 217 p.

Fishman, M.J., and Friedman, L.C., eds., 1989, Methods for determination of inorganic substances in water and fluvial sediments; U.S. Geological Survey Techniques of WaterResources Investigations, book 5, chap. A1, 545 p.

Furlong, E.T., Cahill, J.D., Werner, S.L., Burkhardt, M.R., Kolpin, D.W., and Gates, P.M., 2000, High-performance liquid chromatography/electrospray ionization-mass spectrometric analysis of agricultural and human health pharmaceuticals in samples of ground and surface water, in 
Emerging Issues Conference of the National Ground Water Association, June 7-8, 2000, Minneapolis, Minn., p. 6.

Hauck, H.S., and Harris, T.E., 2006, Water resources data, Missouri, water year 2005: U.S. Geological Survey WaterData Report MO-05-1, 723 p. (published annually).

Helsel, D.R., and Hirsch, R.M., 1992, Statistical methods in water resources: New York, Elsevier Science Publishing Co., 522 p.

Hem, J.D., 1985, Study and interpretation of the chemical characteristics of natural water: U.S. Geological Survey Water-Supply Paper 2254, 3d ed., 263 p.

Horowitz, A.J., 1985, A primer on trace metal sediment chemistry: U.S. Geological Survey Water- Supply Paper 2277, $57 \mathrm{p}$.

Imes, J.L., 1989, Analysis of the effect of pumping on groundwater flow in the Springfield Plateau and Ozark aquifers near Springfield, Missouri: U.S. Geological Survey WaterResources Investigations Report 89-4079, 63 p.

Indiana Business Research Center, 2006, USA counties in profile: STATS Indiana, accessed December 2006 at URL http://www.stats.indiana.edu/uspr/a/us_profile_frame. html?S29?C119.

Insightful Corporation, 2005, S-Plus for Windows-Professional Developer, version 7: Seattle, Wash.

Jeffrey, Alan, Kaplan, Isaac, Zhang, Dachun, Lu, Shan-Tan, and Nielsen, Jesper, 1997, Identifying the sources of nitrate contamination in groundwater, accessed August 2007 at URL http://www.dpra.com/File/zymaxstableisotope.pdf.

Kolpin, D.W., Furlong, E.T., Meyer, M.T., Thurman, E.M., Zaugg, S.D., Barber, L.B., and Buxton, H.T., 2002, Pharmaceuticals, hormones, and other organic wastewater contaminants in U.S. streams, 1999-2000: A national reconnaissance: Environmental Science and Technology, v. 36, no. 6, p. 1,202-1,211.

Lindsey, B.D., and Koch, M.L., 2004, Determining sources of water and contaminants to wells in a carbonate aquifer near Martinsburg, Blair County, Pennsylvania, by use of geochemical indicators, analysis of anthropogenic contaminants, and simulation of ground-water flow: U.S. Geological Survey Scientific Investigations Report 2004-5124, $46 \mathrm{p}$.

Luoma, S.N., 1990, Processes affecting metal concentrations in estuarine and coastal marine sediments, in Furness, R.W., and Rainbow, P.S., (eds.), Heavy metals in the marine environment, Boca Raton, Fla., CRC Press.

Mahler, B.J., 2003, Quality of sediment discharging from the Barton Springs system, Austin, Texas, 2000-2002: U.S. Geological Survey Fact Sheet 089-03, 6 p.
Mariotti, A., 1983, Atmospheric nitrogen is a reliable standard for natural $15 \mathrm{~N}$ abundance measurements: Nature, v. 303, p. 685-687.

Missouri Census Data Center, 2006, Population estimates reports: accessed December 2006 at URL http://mcdc. missouri.edu/pub/data/popests/Curmoest.xls.

Missouri Department of Conservation, 2006, Elk River watershed: accessed November 2006 at URL http://www.mdc. mo.gov/fish/watershed/elk/location.

Missouri Department of Natural Resources, 1998, Section 303(d) waters: accessed December 2006 at URL http:// www.dnr.mo.gov/env/wwp/waterquality/1998_303d_list.pdf.

Missouri Department of Natural Resources, 2004, Total maximum daily load (TMDL) for the Elk River BasinMcDonald, Barry and Newton Counties, Missouri; Benton County, Arkansas: Jefferson City, Water Pollution Control Program, 47 p.

Missouri Department of Natural Resources, 2005, Stream classification and use designations: Rules of Department of Natural Resources Division 20-Clean Water Commission Chapter 7-Water Quality, accessed February 2007 at URL http://www.sos.mo.gov/adrules/csr/current/10csr/10csr.asp.

Missouri Department of Natural Resources, 2006, State operating permits: Water Pollution Control Program, accessed December 2006 at URL http://www.dnr.mo.gov/env/wwp/ cafo/index.html.

Missouri Department of Natural Resources, 2007, Final site specific permits, Division of Environmental Quality: accessed April 2007 at URL http://www.dnr.mo.gov/env/ wpp/permits/wpcpermits-issued.htm .

Missouri Resource Assessment Partnership, 2005, Missouri land use land cover: accessed February 2007 at URL http:// msdis.missouri.edu/html/Lulc2.html

Missouri Watershed Information Network, 2006, Elk River Basin: accessed December 2006 at URL http://www. cerc.usgs.gov/morap/Assets/maps/MoRap_2005_lulc_ Mo2005_003.pdf.

Myers, D.N., and Wilde, F.D., eds, 1997, National field manual for the collection of water-quality data-Biological indicators: U.S. Geological Survey Techniques of WaterResources Investigations, book 9, chap. A7, 38 p.

Myers, D.N., and Wilde, F.D., eds, 2003, Biological indicators (3d ed.): U.S. Geological Survey Techniques of WaterResources Investigations, book 9, chap. A7, accessed July 2007 at URL http://water.usgs.gov/owq/FieldManual.

National Drought Mitigation Center, 2007, University of Nebraska-Lincoln, accessed April 2007 at URL http://www. drought.unl.edu/dm/archive.html. 
National Oceanic and Atmospheric Administration, 1999-2003, Climatologic data annual summary, Missouri: Asheville, North Carolina, National Climatic Center, v. 103-107, no. 13 .

National Oceanic and Atmospheric Administration, 2004 2006, Climatologic data monthly, Missouri: Asheville, North Carolina, National Climatic Center, v. 108-110, no. $1-12$.

Rantz, S.E., and others, 1982, Measurement and computation of streamflow-Volume 1. Measurement of stage and discharge: U.S. Geological Survey Water-Supply Paper 2175, $284 \mathrm{p}$.

Runkel, R.L., Crawford, C.G., and Cohn, T.A., 2004, Load estimator (LOADEST) - A FORTRAN program for estimating constituent loads in streams and rivers: U.S. Geological Survey Techniques and Methods Report 4-A5, $75 \mathrm{p}$.

Schumacher, J.G., 2001, Water quality in the Upper Shoal Creek Basin, southwestern Missouri, 1999-2000: U.S. Geological Survey Water-Resources Investigations Report 01-4181, 60 p.

Sigman, D.M., Casciotti, K.L., Andreani, M., Barford, C., Galanter, M., and Böhlke, J.K., 2001, A bacterial method for the nitrogen isotopic analysis of nitrate in seawater and freshwater: Analytical Chemistry, v. 73, p. 4,145-4,153.

Tukey, J.W., 1977, Eexploratory data analysis: Reading, Mass., Addison-Wesley, 688 p.
University of Arkansas, 1997, Center for Advanced Spatial Technologies: accessed February 2007 at URL http://www. cast.uark.edu/cast/research/lulc.

U.S. Department of Agriculture, 2006, National Agriculture Statistics Service-Quick stats: accessed December 2006 at URL http://www.nass.usda.gov/QuickStats.

Wilde, F.D., and Radtke, D.B., eds., 1998, National field manual for the collection of water-quality data-Field measurements: U.S. Geological Survey Techniques of WaterResources Investigations, book 9, chap. A6, 238 p.

Wilde, F.D., Radtke, D.B., Gibs, J., and Iwatsubo, R.T., eds., 1999a, National field manual for the collection of waterquality data-Collection of water samples: U.S. Geological Survey Techniques of Water-Resources Investigations, book 9, chap. A4, 103 p.

Wilde, F.D., Radtke, D.B., Gibs, J., and Iwatsubo, R.T., eds., 1999b, National field manual for the collection of waterquality data-Processing of water samples: U.S. Geological Survey Techniques of Water-Resources Investigations, book 9, chap. A5, $128 \mathrm{p}$.

Zauug, S.D., Smith, S.G., Schroeder, M.P., Barber, L.B., and Burkhardt, M.R., 2001, Methods of analysis by the U.S. Geological Survey National Water Quality LaboratoryDetermination of wastewater compounds by polystyrene divinylbenzene solid-phase extraction and capillary-column gas chromatography/mass spectrometry: U.S. Geological Survey Water-Resources Investigations Report 01-4186, p. 37. 
Prepared by:

USGS Enterprise Publishing Network

Rolla Publishing Service Center

1400 Independence Road

Rolla, M0 65401

For more information concerning this publication, contact:

Director

U.S. Geological Survey

Missouri Water Science Center

1400 Independence Road

Rolla, M0 65401

(573) 308-3667

Or visit the Missouri Water Science Center website at:

http://mo.water.usgs.gov 

